\title{
Department Chairs' Perceptions of Part-Time Faculty Status in Maryland Public and Private Higher Education Institutions
}

\author{
Daniel L. Moorehead \\ West Virginia University
}

Follow this and additional works at: https://researchrepository.wvu.edu/etd

\section{Recommended Citation}

Moorehead, Daniel L., "Department Chairs' Perceptions of Part-Time Faculty Status in Maryland Public and Private Higher Education Institutions" (2011). Graduate Theses, Dissertations, and Problem Reports. 4757.

https://researchrepository.wvu.edu/etd/4757

This Dissertation is protected by copyright and/or related rights. It has been brought to you by the The Research Repository @ WVU with permission from the rights-holder(s). You are free to use this Dissertation in any way that is permitted by the copyright and related rights legislation that applies to your use. For other uses you must obtain permission from the rights-holder(s) directly, unless additional rights are indicated by a Creative Commons license in the record and/ or on the work itself. This Dissertation has been accepted for inclusion in WVU Graduate Theses, Dissertations, and Problem Reports collection by an authorized administrator of The Research Repository @ WVU.

For more information, please contact researchrepository@mail.wvu.edu. 
Department Chairs' Perceptions of Part-Time Faculty Status in Maryland Public and Private Higher

Education Institutions

\author{
Daniel L. Moorehead \\ Dissertation submitted to the \\ College of Human Resources and Education \\ at West Virginia University \\ in partial fulfillment of the requirements \\ for the degree of
}

Doctor of Education

in

Educational Leadership Studies

\author{
Approved by \\ Ernest R. Goeres, Ph.D., Chair \\ Deborah Hendricks, Ed.D. \\ Ted Price, Ph.D. \\ Patricia Obenauf, Ed.D. \\ Terry Russell, Ph.D. \\ Department of Advanced Educational Studies
}

Morgantown, West Virginia

2011

Keywords: Adjunct, Part-time Faculty, Higher Education, Department Chairs Copyright 2011 Daniel L. Moorehead 


\author{
ABSTRACT \\ Department Chairs' Perceptions of Part-Time Faculty Status \\ in Maryland Public and Private Higher \\ Education Institutions \\ Daniel L. Moorehead
}

The growing use of part-time, non-tenure track faculty in higher education has become a nationwide phenomenon. The college-teaching part-time instructor is one who is working for low pay, has little job security, and has few benefits. College part-time instructors' employment is in a contingent state. They do not have the job protection provided to tenured professors because they are usually hired for only the upcoming term with no guarantee of being hired for any future terms.

The purpose of this study was to describe the status of part-time faculty in Maryland public and private four-year colleges and universities as perceived by department chairs and to explore whether there are significant differences between private versus public on each of the five areas of study. The five areas were (1) extent of information collected on the professional commitments of their adjunct faculty, (2) extent adjunct faculty are evaluated and what evidence is required, (3) extent adjunct faculty become integrated into the department, (4) extent performance expectations are explained to adjunct faculty, and (5) extent adjunct faculty are satisfied with employment conditions in the department.

A cover letter and seven-page survey was sent to identified Maryland public and private fouryear college and university department chairs using Survey Monkey®. For this particular study, descriptive statistics and ANOVAs were used as appropriate measures. Statistical results revealed there was a significant difference $(p<.10)$ between chairs from public and private institutions on their composite scores in the area of the extent adjunct faculty are evaluated and the evidence required. Department chairs from private institutions recorded a higher mean score than department chairs from public institutions, indicating chairs from private institutions agreed more with this statement, resulting in a higher mean score. Conducting Cross-Tabulation, a strong, significant association (Cramer's $\mathrm{V}=.317, p<.05$ ) was found between the type of school (public/private) and the survey question that adjunct faculty are expected to use studentcentered effective teaching techniques. While both groups tended to agree with this statement, chairs from private institutions were much more spilt in their responses.

There were no significant differences between chairs from public and private institutions on their composite scores in the area of information collected on the professional commitments of their adjunct faculty, in the area of adjunct faculty becoming integrated into the department, in the area of performance expectations being explained to adjunct faculty, and in the area of adjunct faculty satisfaction with employment conditions in the department. 


\section{AKNOWLEDGEMENTS}

This project would have been impossible to complete without the help and support of some remarkable individuals. First, I would like to express my gratitude and appreciation to my chair, Dr. Ernest Goeres. His willingness to accept the challenge as the chair and unwavering commitment to this project has made for an incredible learning experience. His meticulous attention to detail and thoughtful suggestions only made for a much better end result. His guidance, support and encouragement throughout this project were immeasurable.

I am most appreciative to Dr. Deborah Hendricks, without her guidance and patience; I could not have completed this dissertation. I learned a great deal from her, information I won't soon forget. Special thanks to Dr. Ted Price who could have easily said no to serving on the committee due to his new faculty appointment but he didn't. I am grateful to Dr. Patricia Obenauf, who willingly agreed to serve on the committee. Thanks to Dr. Richard Walls for filing in for Dr. Obenauf during the defense. To my friend and colleague, Dr. Terry Russell, department chair of social work at Frostburg State University, I am so grateful for all your help and support. You not only provided me the opportunity to teach, but your expertise in statistics was invaluable on this study. To Dr. Robert Moore, my friend, colleague, and sociology department chair, Frostburg State University a special thanks for your continued encouragement and support. Special thanks to Ms. Selina Steele, Assistant Director of Institutional Research, Frostburg State University. Without your help, I could not have developed the survey instrument. 


\section{TABLE OF CONTENTS}

Chapter One: Introduction of the Study ........................................................... 1

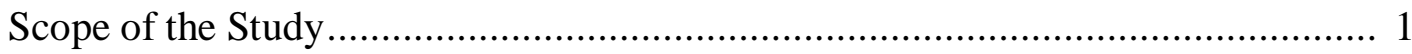

Statement of the Problem ...................................................................... 9

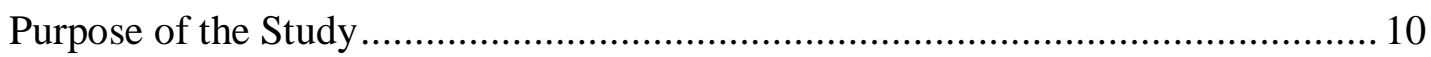

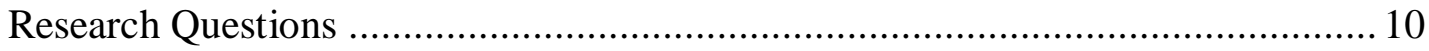

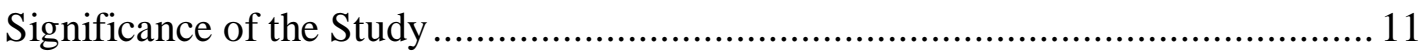

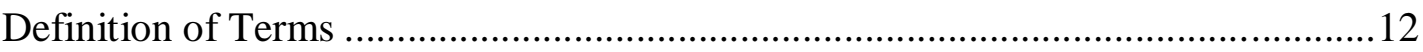

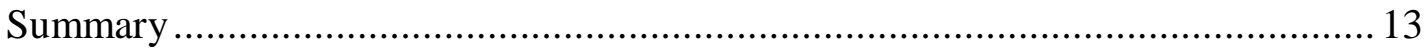

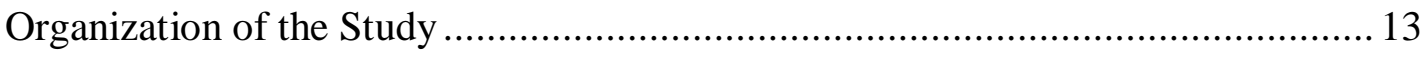

Chapter Two: Review of the Literature.................................................................. 14

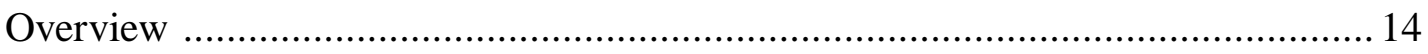

Defining Part-Time/Adjunct Faculty ................................................... 14

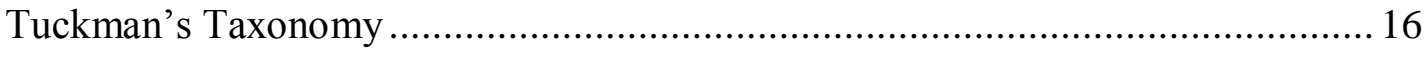

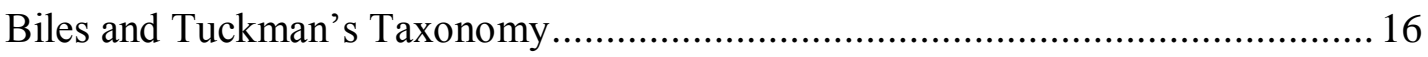

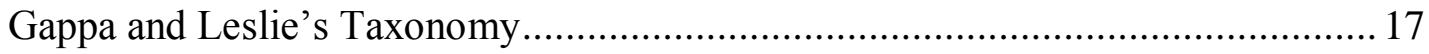

Advantages of Using Part-Time/Adjunct Faculty ........................................... 19

Disadvantages of Using Part-Time/Adjunct Faculty ...................................... 22

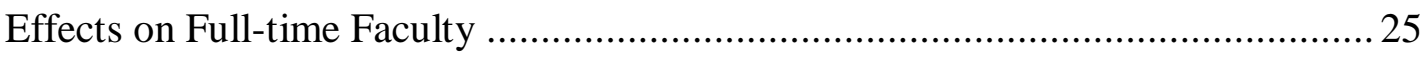

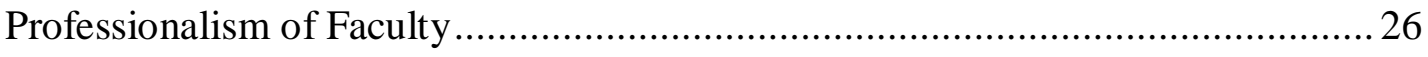

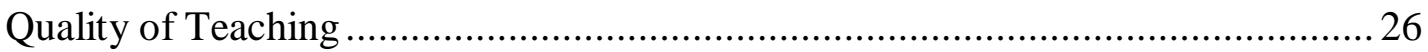

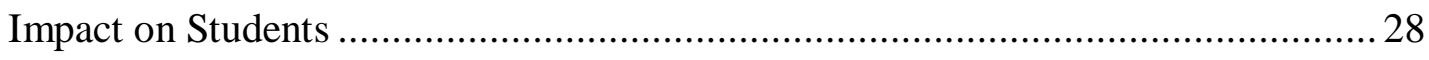

Professional Commitments of Part-Time/Adjunct Faculty ................................. 29 


\section{ADJUNCT FACULTY STATUS}

Evaluation of Part-Time/Adjunct Faculty ..................................................... 30

Evaluation through Professional Development............................................... 31

Integration of Part-Time/Adjunct Faculty into the Department ............................ 32

Performance Expectations of Part-Time/Adjunct Faculty .................................. 35

Employment Conditions of Part-Time/Adjunct Faculty..................................... 35

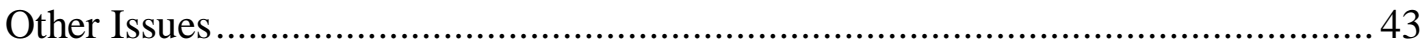

Collective Bargaining ............................................................................. 43

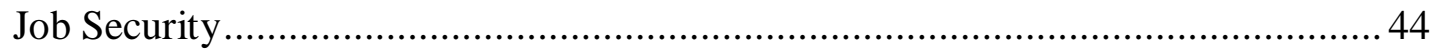

Review of Related Research ................................................................. 45

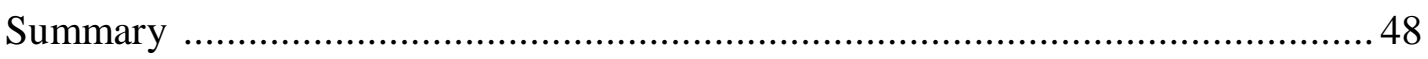

Chapter Three: Research Methodology ......................................................... 50

Restatement - Purpose of the Study ..................................................... 50

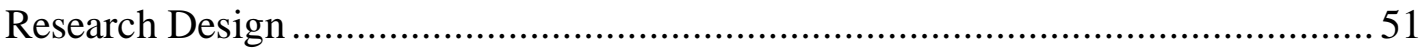

Population and Sample .......................................................................... 51

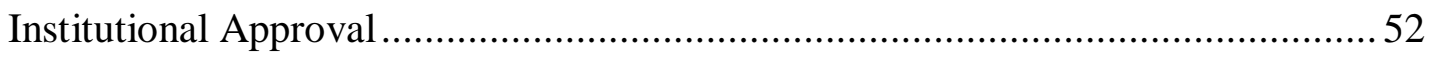

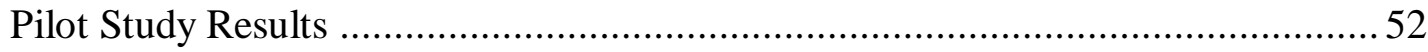

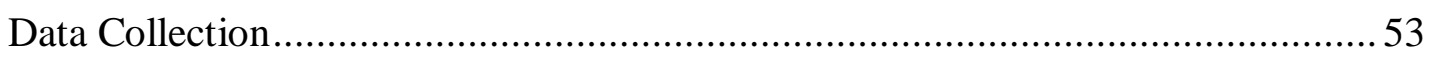

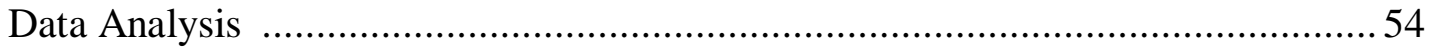

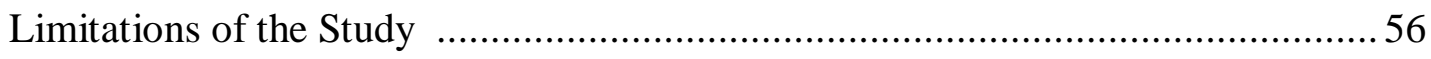

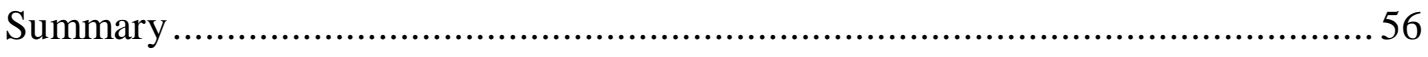

Chapter Four: Findings............................................................................. 57

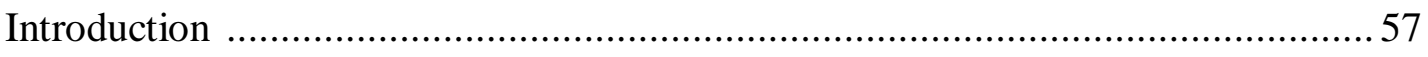

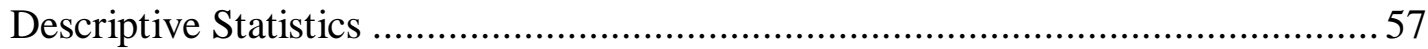




\section{ADJUNCT FACULTY STATUS}

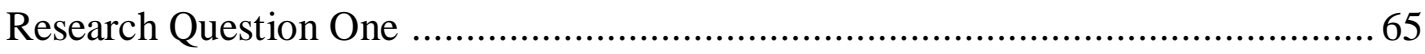

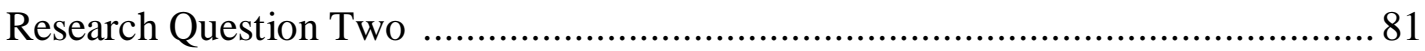

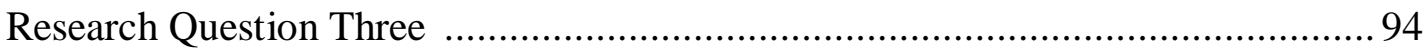

Research Question Four .................................................................. 104

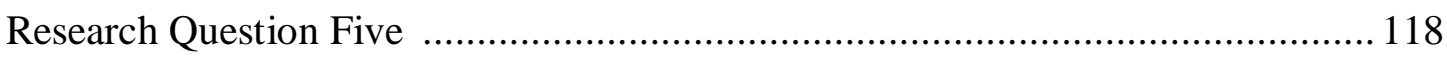

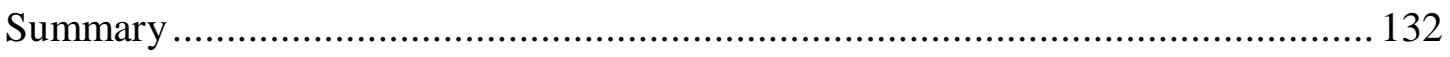

Chapter Five: Summary, Conclusions, Recommendations ...................................... 133

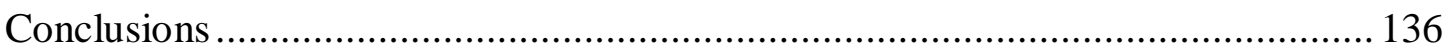

Recommendations for Practice................................................................ 144

Recommendations for Further Study...................................................... 145

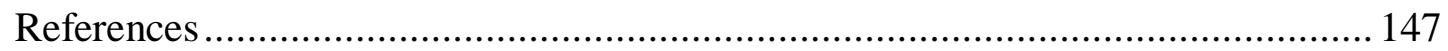

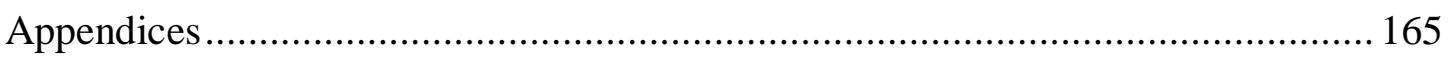

Appendix A: Expedited-IRB Protocol-Exemption Form ... ............................ 165

Appendix B: Cover Letter to Survey Participants .......................................... 167

Appendix C Part-time Faculty Survey (Department Chairs) .............................. 168 


\section{List of Tables}

Table 1 Percentage distribution of all faculty and instructional staff ............................ 3

Table 2 Trends in Faculty Status, 1975-2007 ...................................................... 5

Table 3 Variables, Research Questions, and Items on Survey ..................................... 55

Table 4 Gender of Chairs Completing Survey .................................................... 59

Table 5 Years Served as Department Chair .......................................................... 59

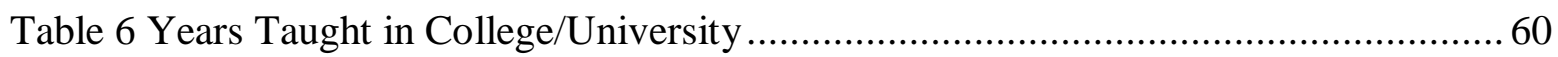

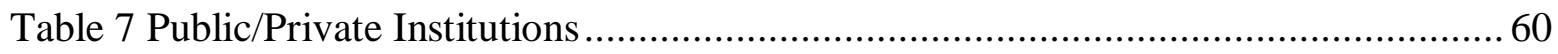

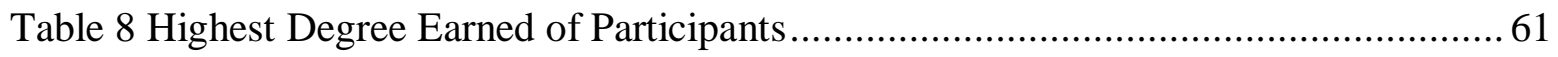

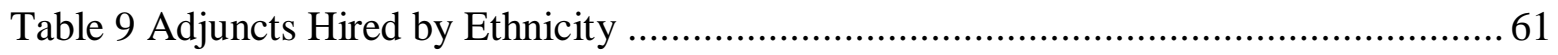

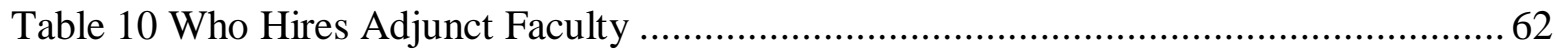

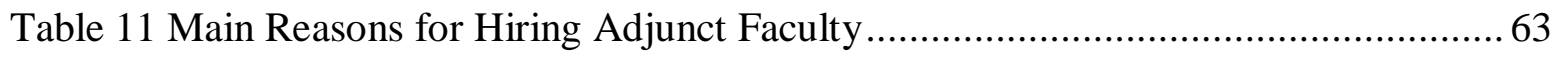

Table 12 Maximum Number Credit hours Adjuncts can Teach.................................... 63

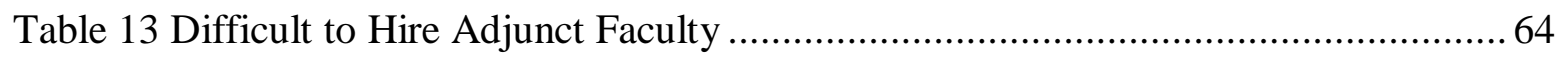

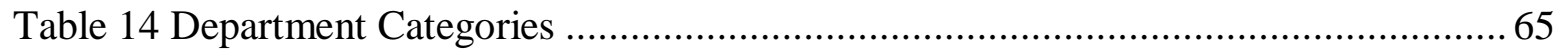

Table 15 Crosstab: Adjunct faculty commitments at other institutions is a concern for me 66

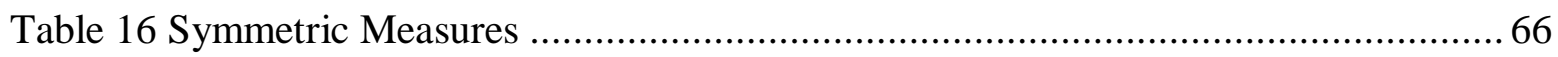

Table 17 Crosstab: Adjunct faculty teaching at other colleges and universities should not

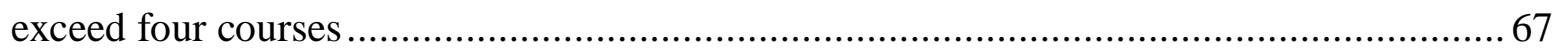

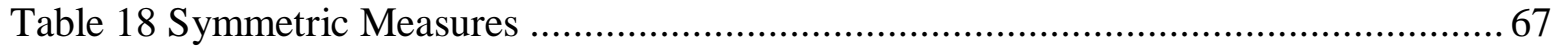

Table 19 Crosstab: Adjunct faculty are required to share information with department chairs

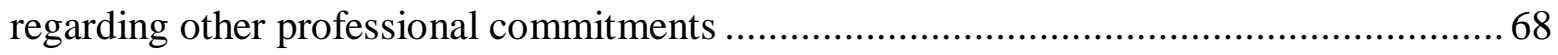

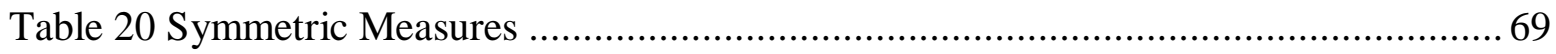




\section{ADJUNCT FACULTY STATUS}

Table 21 Crosstab: There is a limit on the number of courses adjunct teach elsewhere....... 70

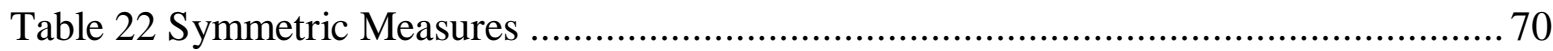

Table 23 Crosstab: Adjunct faculty are required to inform department chairs of other

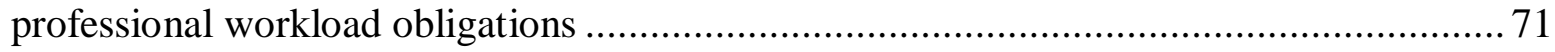

Table 24 Symmetric Measures ............................................................................ 71

Table 25 Crosstab: Having several outside professional commitments raises concern in their

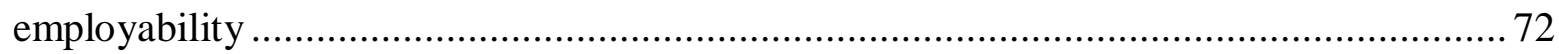

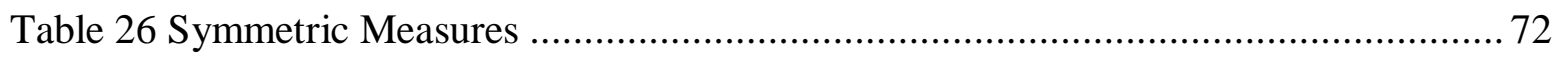

Table 27 Crosstab: There should be limitations on outside professional commitments for adjunct

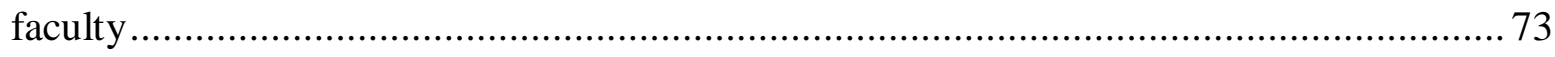

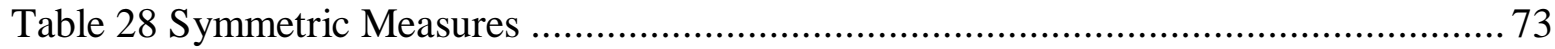

Table 29 Crosstab: My institution has a set hiring policy or contract for adjunct faculty .... 74

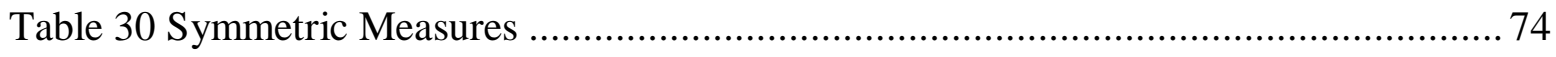

Table 31 Crosstab: Locally recruited adjunct faculty are less competent than those hired through

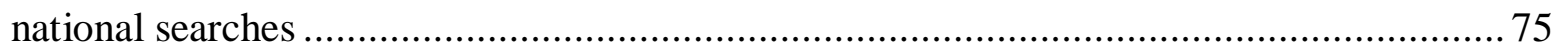

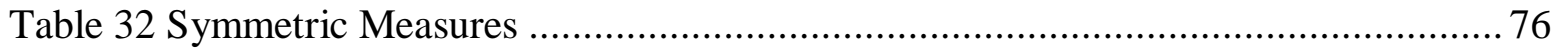

Table 33 Crosstab: Due to their lack of full-time commitment, adjunct faculty devote insufficient

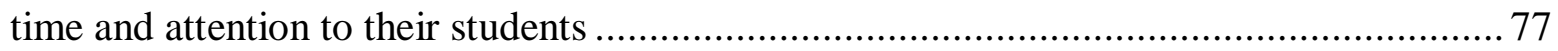

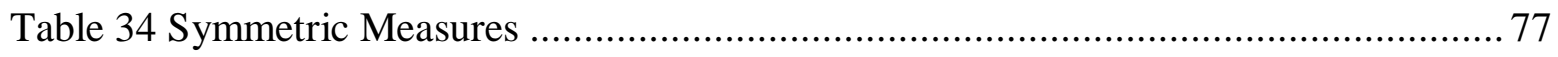

Table 35 Crosstab: Not every adjunct is hired for reasons of cost; many are hired to meet special

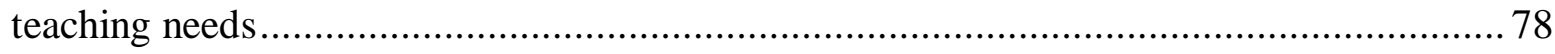

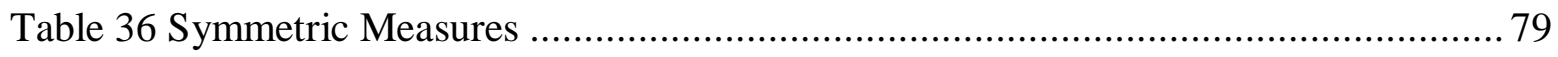




\section{ADJUNCT FACULTY STATUS}

Table 37 Crosstab: Adjunct faculty are often retained and reappointed over extended periods of time despite non-tenure-track instructional titles.................................................... 80

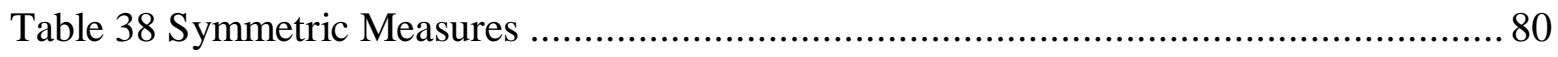

Table 39 Descriptives: Research Question by Public/Private Institutions ....................... 81

Table 40 ANOVA: Research Question by Public/Private Institutions ............................. 81

Table 41 Crosstab: Adjunct faculty should be evaluated the same as full time faculty ....... 82

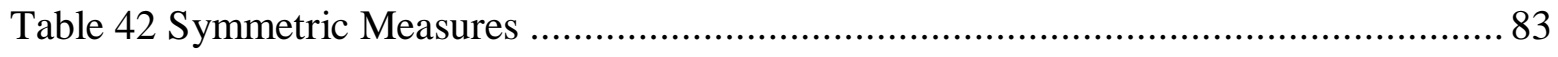

Table 43 Crosstab: Adjunct faculty should be evaluated in the classroom by peer faculty

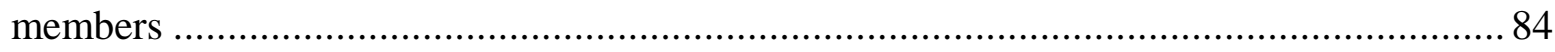

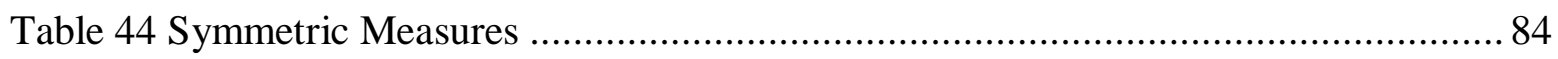

Table 45 Crosstab: Adjunct faculty should be evaluated by Institutional student evaluations at the

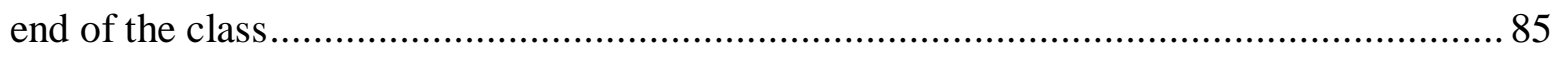

Table 46 Symmetric Measures ........................................................................ 85

Table 47 Crosstab: Adjunct faculty should be evaluated by department chairs only .......... 86

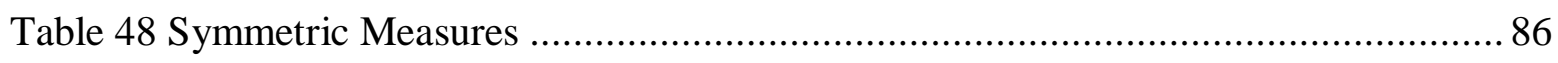

Table 49 Crosstab: Evaluation of teaching effectiveness is mandatory ......................... 87

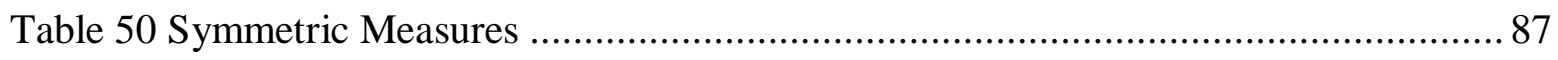

Table 51 Crosstab: Our institution has policies for formal evaluation of adjuncts .............88

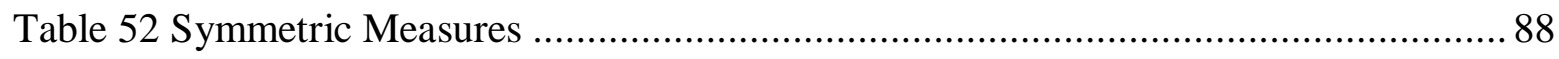

Table 53 Crosstab: Adjunct faculty do evaluate themselves through informal methods...... 89

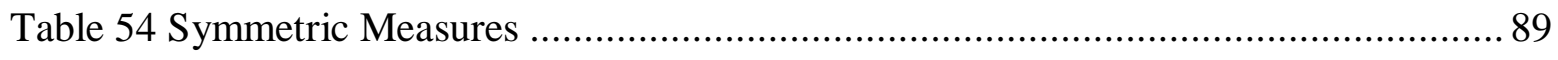

Table 55 Crosstab: Part-time, adjunct faculty are very effective teachers ...................... 90

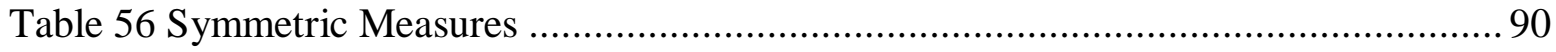




\section{ADJUNCT FACULTY STATUS}

Table 57 Crosstab: Evaluations for adjunct faculty are consistently higher than for tenure-track faculty members

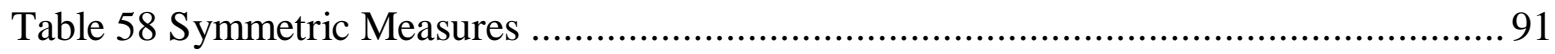

Table 59 Crosstab: The use of adjunct faculty will continue to grow in the future............. 92

Table 60 Symmetric Measures ............................................................................. 92

Table 61 Descriptives: Research Question by Public/Private Institutions ....................... 93

Table 62 ANOVA: Research Question by Public/Private Institutions ........................... 93

Table 63 Crosstab: Adjunct faculty understand the program's mission ......................... 94

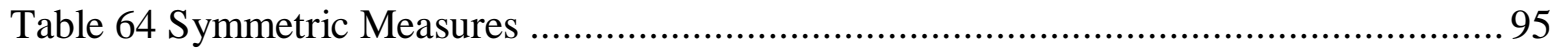

Table 65 Crosstab: Adjunct faculty understand the program's learning outcomes ............. 95

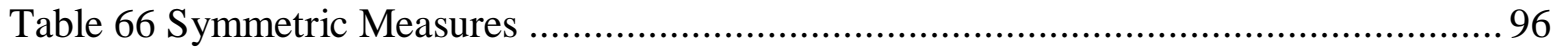

Table 67 Crosstab: Adjunct faculty understand how courses they teach fit into the appropriate

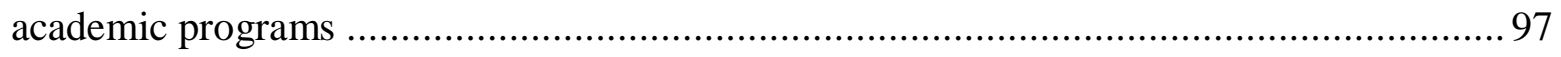

Table 68 Symmetric Measures ............................................................................ 97

Table 69 Crosstab: Students report that adjunct faculty members are rarely available

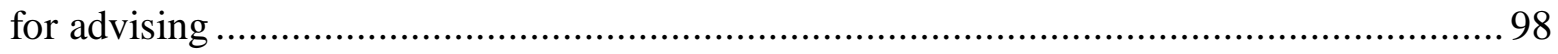

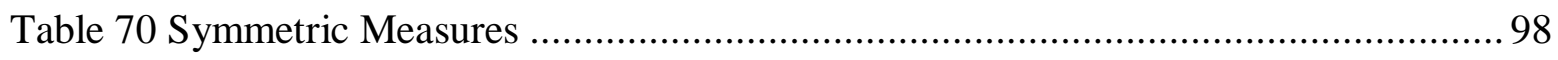

Table 71 Crosstab: Adjunct faculty are included in planning discussions about current and

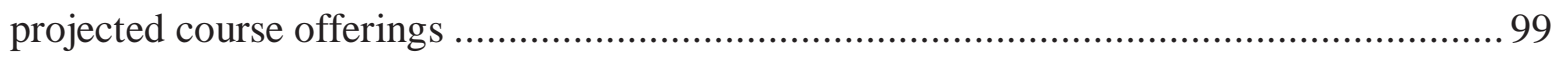

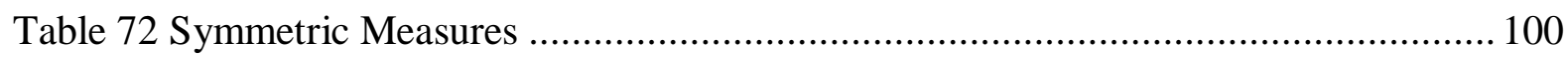

Table 73 Crosstab: Adjunct faculty are included in planning discussions about current and projected use of resource allocations, budget projections, and actual and anticipated sources of

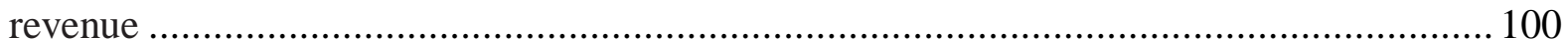




\section{ADJUNCT FACULTY STATUS}

Table 74 Symmetric Measures 101

Table 75 Crosstab: Adjunct faculty are included in the formulation of strategies and plans that reflect the mission and educational objectives of the department and institution 102

Table 76 Symmetric Measures 102

Table 77 Descriptives: Research Question by Public/Private Institutions 103

Table 78 ANOVA: Research Question by Public/Private Institutions 103

Table 79 Crosstab: Adjunct faculty are expected to maintain regular office hours 104

Table 80 Symmetric Measures 105

Table 81 Crosstab: Adjunct faculty are expected to serve as an advisor to students. 106

Table 82 Symmetric Measures 106

Table 83 Crosstab: Adjunct faculty are expected to develop their course syllabi..... 107

Table 84 Symmetric Measures 107

Table 85 Crosstab: Adjunct faculty are expected to conduct assessments of student learning 108

Table 86 Symmetric Measures . 108

Table 87 Crosstab: Adjunct faculty are expected to use student-centered effective teaching techniques

Table 88 Symmetric Measures 109

Table 89 Crosstab: Adjunct faculty are expected to engage in and publish research

Table 90 Symmetric Measures

Table 91 Crosstab: Adjunct faculty are expected to be involved in governance issues

Table 92 Symmetric Measures 


\section{ADJUNCT FACULTY STATUS}

Table 93 Crosstab: Adjunct faculty are expected to serve on college and departmental committees.

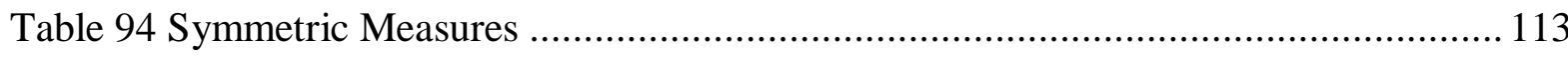

Table 95 Crosstab: Adjunct faculty are expected to serve on student committees.............. 114

Table 96 Symmetric Measures

Table 97 Crosstab: Adjunct faculty members fully understand the expectations of satisfactory performance

Table 98 Symmetric Measures

Table 99 Crosstab: Adjunct faculty members understand their role in contributing to the

overall curriculum

Table 100 Symmetric Measures

Table 101 Descriptives: Research Question by Public/Private Institutions

Table 102 ANOVA: Research Question by Public/Private Institutions

Table 103 Crosstab: Adjunct faculty are satisfied with their part-time status

Table 104 Symmetric Measures

Table 105 Crosstab: Adjunct faculty are more satisfied as a contractual employee rather than

part-time employee status.

Table 106 Symmetric Measures 120

Table 107 Crosstab: Adjunct faculty are satisfied with their salaries

Table 108 Symmetric Measures

Table 109 Crosstab: Adjunct faculty are eligible for salary increases from one year to the

next.......... 


\section{ADJUNCT FACULTY STATUS}

Table 111 Crosstab: Adjunct faculty are satisfied with the conditions for reappointment ... 123

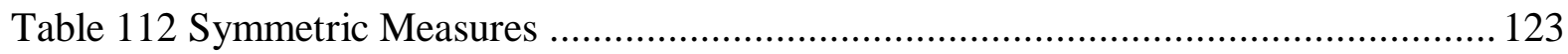

Table 113 Crosstab: Adjunct faculty have opportunities for promotion......................... 124

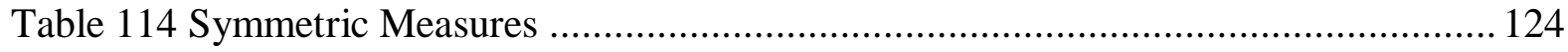

Table 115 Crosstab: Adjunct faculty are satisfied with secretarial support they receive ..... 125

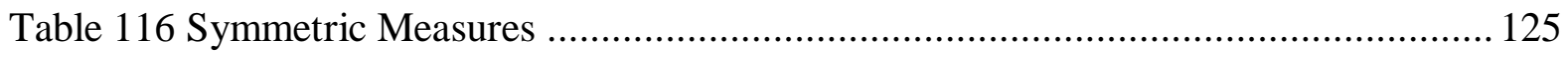

Table 117 Crosstab: Adjunct faculty are satisfied with office space and equipment made

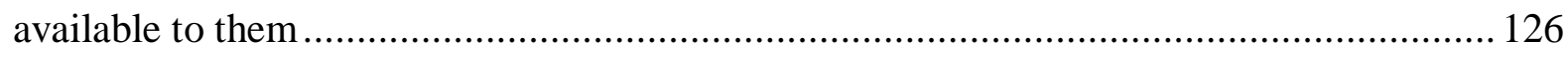

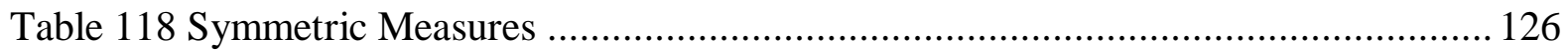

Table 119 Crosstab: Adjunct faculty are included in departmental social events .............. 127

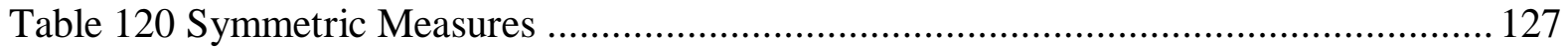

Table 121 Crosstab: Adjunct faculty are satisfied with the number of credit hours they can

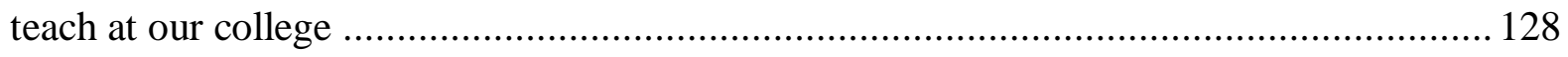

Table 122 Symmetric Measures ......................................................................... 129

Table 123 Crosstab: Adjunct faculty are hired as part-time employees rather than

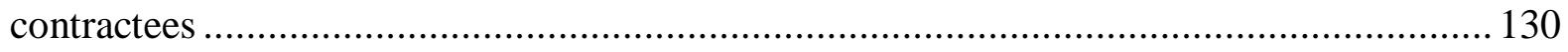

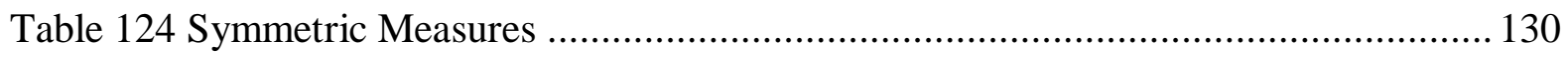

Table 125 Descriptives: Research Question by Public/Private Institutions ....................... 131

Table 126 ANOVA: Research Question by Public/Private Institutions .......................... 131 


\section{Chapter One:}

\section{Introduction of the Study}

The growing use of part-time, non-tenure track faculty (also known as adjuncts) in higher education has become a nationwide phenomenon. "Part-time faculty" generally refers to nontenured teaching personnel hired to teach less than a full-time course load per semester. For clarity and consistency, the terms part-time, adjunct, and contingent faculty are used interchangeably throughout this study.

The part-time instructor is often isolated, independent, and unattached to the world of the university. A two-tier ranking of faculty within the university exists; the top tier is the full-time faculty with tenure and a living wage versus the part-time instructor in the lower tier faced with low pay, lack of job security, and poor working conditions (Smallwood, 2003). One of the consequences of the lower tier status is part-time instructors are not provided the protection garnered by the top tier (tenured) faculty (Elman, 2003). Elman is suggesting by no protection that there are often no or few policies available to protect the part-time instructor, especially when it comes to academic governance.

According to Aronowitz (1998), the college teaching adjunct or part-time instructor is one who is working for low pay, has little job security, and has few benefits. College part-time instructors' employment is in a contingent state. They do not have the job protection provided to tenured professors because they are usually hired for only the upcoming term with no guarantee of being hired for any future terms. Part-time instructors, in fact, are not really ever fired; their contracts are simply not renewed. This can happen when a course the part-time instructor was teaching is not offered for a term or when an administrator has any question as to the instructor's 
worth or, even more distressing, when a controversy arises with the part-time instructor and the educational institution does not want to deal with it.

Rhoades (1998) stated:

One of the greatest sources of managerial flexibility in allocating faculty resources is the use of part-time faculty, who may be hired and released far more easily than full-timers. And managers are exercising that flexibility to hire increased numbers of part-time faculty. (pp. 46-47)

Because part-time instructors have little, if any, control of their situations, they are not only marginalized but are put in a situation where they are challenged to just stay employed every time a term or semester comes to an end.

Across the United States, institutions of higher education have increasingly relied upon part-time or full-time non-tenure faculty members to teach for-credit and non credit courses (American Association of University Professors, 2006; Anderson, 2002; Baldwin \& Chronister, 2001; Conley, Lesley \& Zimbler, 2002; Ehrenberg \& Zhang, 2005; Elman 2003). Curtis (2005) reports that in 1975, full-time tenured and tenure-track faculty members made up approximately $56 \%$ of the faculty at America's 2-year and 4-year colleges and universities, while full-time non tenure-track faculty and part-time faculty comprised $13 \%$ and 30\%, respectively. By 2003 fulltime tenured and tenure-track faculty had fallen to $35 \%$ while the latter two categories had risen to approximately $19 \%$ and $46 \%$, respectively.

According to Cataldi, Fahimi, \& Bradburn, (2005), 56\% of all postsecondary faculty were employed full-time and 44\% were employed part-time in fall 2003 (see Table 1). About two-thirds $(67 \%)$ of faculty employed in public associate's institutions reported working part 
time, compared with 22 to $55 \%$ of faculty at other types of institutions. Table 1 shows the

distribution of instructional faculty by employment status in 2003 .

Table 1

Percentage distribution of all faculty and instructional staff, by employment status, institution type, and program area: Fall 2003.

Institution type and program area Employment status

Full-Time

56.3

77.8

68.7

63.3

45.1

63.2

33.3

49.3

66.1

78.4

54.0

51.3

78.2

53.0

69.7

65.4

76.5

70.3

62.6
Part-Time

22.2

31.4

36.7

54.9

36.8

66.7

50.8

33.9

21.6

46.0

48.7

21.8

47.0

30.3

34.6

23.5

29.7

37.4

All other fields

(1)All public and private not-for-profit Title IV degree-granting institutions in the 50 states and the District of Columbia.

(2) Doctoral includes research/doctoral institutions, and specialized medical schools and medical centers as classified by the 2000 Carnegie Classification.

(3) Public baccalaureate, private not-for-profit associate's, and other specialized institutions, except medical schools and medical centers.

NOTE: All faculty and instructional staff includes all faculty (regardless of whether they had instructional responsibilities) and all other instructional staff. Detail may not sum to totals because of rounding.

SOURCE: Cataldi, F. E., Fahimi, M., \& Bradburn, E. M., (2005). U.S. Department of Education, National Center for Education Statistics, 2004 National Study of Postsecondary Faculty. 
While there may be several explanations for this trend, Cataldi et al. (2005) suggests it is related, at least in part, to economics. Aside from economics, there may be additional reasons institutions of higher education hire part-time faculty. They include the desire to offer specialty courses the need to temporarily replace full-time faculty members who have left, are on sabbatical, or on extended leave; the desire to provide full-time faculty members with more time for research and the need to provide the institution with added flexibility in course offerings.

Adjuncts make up $67 \%$ of the faculty in community colleges across the nation (Cataldi et al., 2005) and have similar credentials to those of their full-time counterparts, yet encounter working conditions markedly less desirable than full-time colleagues (Christensen, 2008; Cohen \& Brawer, 1996; Ehrenberg \& Zhang, 2004; Gappa, Austin, \& Trice, 2007; Gappa \& Leslie, 1997).

The overall growth of part-time faculty appointments between 1975 and 2007 became the majority of all faculty positions at degree-granting colleges and universities (AAUP, 2007). During this period, full-time tenured positions declined from $37 \%$ of all faculty positions to only $22 \%$. This occurred during a time of overall growth in faculty numbers, but one in which parttime appointments grew much more rapidly than tenure-line positions. In fact, the actual number of full-time tenured faculty positions declined by more than 2,000 between 1995 and 2003 (Curtis \& Jacobe, 2006). Perhaps even more strikingly, the proportion of full-time tenure-track positions declined from 20\% to 10\% during 1995 and 2007 (AAUP, 2007). As documented by Schuster and Finkelstein (2006), the majority of new hires for full-time faculty from 1993 through 2005 were off the tenure track - a phenomenon they label a "seismic shift" (p. 194). Although more part-time faculty members are employed on community college campuses than 
on other campuses, the increase in the overall numbers of adjunct faculty is considerable as clearly indicated in Table 2.

Table 2

Trends in Faculty Status, 1975-2007

All degree-granting institutions; National totals

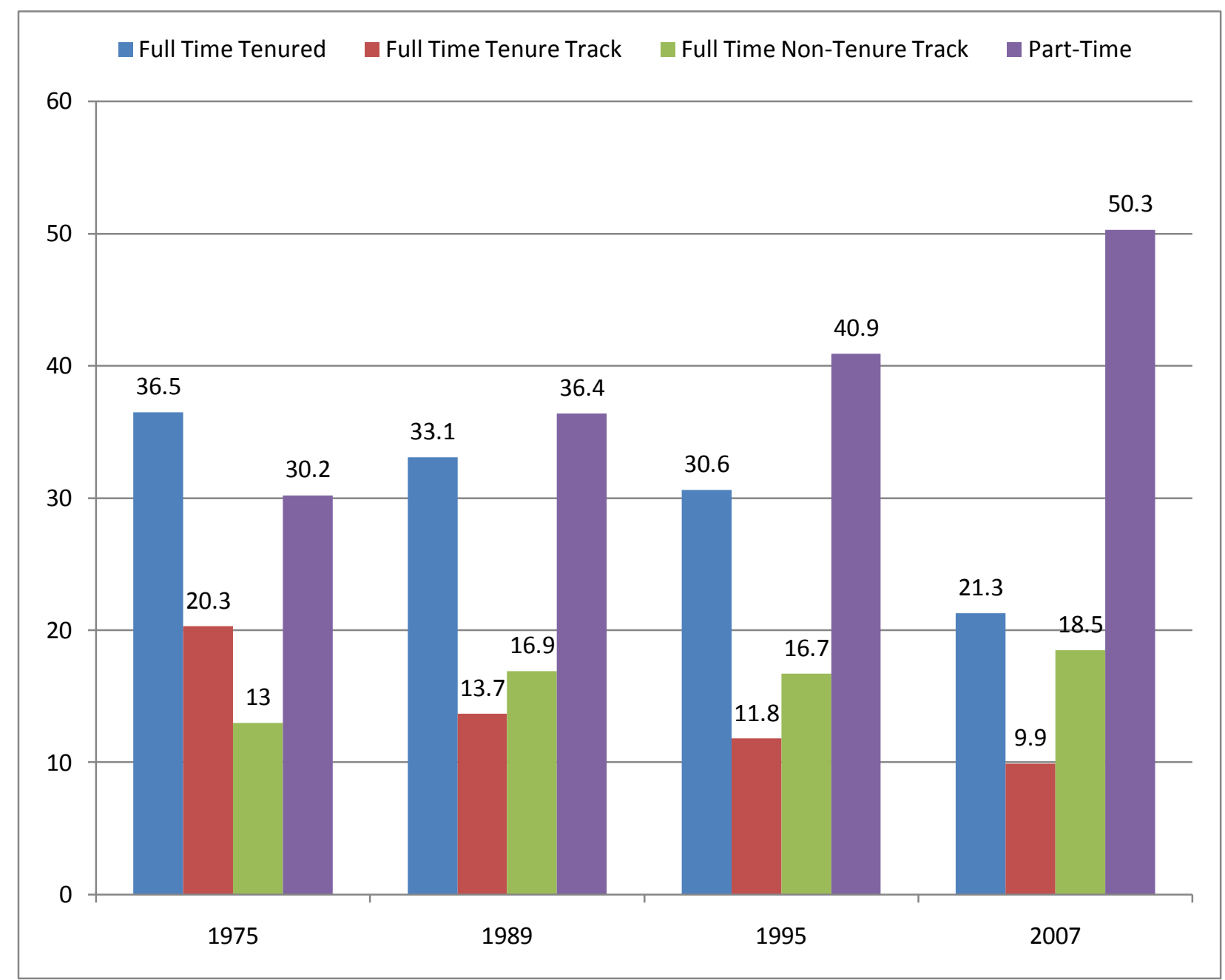

Source: Compiled by the American Association of University Professors (2007). U.S. Department of Education, IPEDS Fall Staff Survey.

On most campuses, adjunct faculty and graduate assistants bear the majority of responsibility for teaching introductory education courses (Green, 2007), while departments use permanent full-time faculty to teach majors in the advanced and graduate courses (Haeger, 1998). One of the most prominent areas in which part-time faculty are used is in undergraduate 
education or lower-division courses (e.g., introductory English composition, basic math and algebra courses). Since community colleges offer mainly lower-division, general education, and technical training courses, these colleges primarily use adjunct faculty (Banachowski, 1996a; Dickinson, 1997).

The increased use of part-time faculty in higher education has led to a great deal of study and discussion. Some areas of interest to scholars have been the political climate surrounding the increased use of part-time faculty (Gappa \& Leslie, 1997; Leslie, 1998), the characteristics of part-time faculty (Clery, 1998; Gappa \& Leslie, 1997; Mellander \& Mellander, 1999), professional development of part-time faculty, (Wallin, 2007) and the quality of part-time faculty (Freeland, 1998; Gappa \& Leslie, 1997; Green, 2007; Leslie, 1998).

The financial climate that has fostered the increased use of part-time faculty in postsecondary schools is one area of interest to scholars. Public institutions of higher education, for example, have been faced with stagnating federal and state funding. At the same time, these institutions have had to contend with increased enrollments and operating expenses (Freeland, 1998; Gappa \& Leslie, 1997; Leslie, 1998). This climate has led to an imperative to control costs (Clery, 1998) and to increase flexibility for administrators and convenience to students in scheduling courses (Freeland, 1998; Leslie, 1998).

Administrators of higher education often view the hiring of part-time faculty as cost effective (Clery, 1998; Mellander \& Mellander, 1999) and convenient (Freeland, 1998). Tenure and tenure-track faculty salaries are among the largest costs (approximately 60-70\%) in the budgets of institutions of higher education. Therefore, the use of part-time faculty who are less expensive than their full-time counterparts is an important mechanism in the control of costs (Knapp, Kelly-Reid, Whitmore, \& Miller, 2007; Leslie, 1998). 
Many, if not all, part-time faculty members' salaries and benefits are less than those of full-time faculty members. Part-time faculty across the nation are paid a fraction of the salary that full-time tenure-track or tenured professors receive (Gappa, et al., 2007) - an average of 40 cents on the dollar compared to full-time faculty (Murphy, 2002). Employment of part-time and adjunct faculty provides additional savings to the institution because minimal or no fringe benefits are available to them (Gappa et al., 2007; Gappa \& Leslie, 1993).

However, part-time faculty members are not required to take on certain administrative and other responsibilities of their full-time counterparts, such as advising students, serving on committees, performing research and writing for professional publications. Part-time faculty members may have only an occasional or temporary affiliation with an institution. In addition, they may not be fully aware of what the institution or specific department expects of them.

Gappa et al. (2007) and Gappa and Leslie (1993) suggest that what had once been a category for special temporary teaching arrangements has become an administrative device for hiring instructors without having to pay benefits that tenure-track positions receive, such as health insurance and pension contributions.

Most agree that pay for part-time and adjunct faculty is appalling compared with fulltime compensation, as these individuals earn less than half of what their tenured colleagues make, and usually earn about two-thirds of a tenure-track salary. Part-time faculty members often teach overloads or courses that very few of the tenured or tenure-track faculty are willing to teach (Fulton, 2000).

As budgets shrink, the employment of adjuncts and other faculty (lecturers, visiting professors, research assistants, graduate assistants) becomes increasingly attractive to institutions. Although there is greater reliance on part-time faculty to teach, primarily the 
introductory sections of general education requirements, these instructors are often marginalized by full-time faculty (Rhoades, 1998) and referred to as "the invisible faculty" by Gappa and Leslie (1993). This term illustrates the lack of status and regard given to adjuncts in higher education.

Since teaching is the central function of colleges and universities, it is clear that the ability to fulfill this function largely hinges on the caliber of part-time faculty. The quality of this faculty, in turn, depends on the institution's capacity to attract and retain competent, motivated, and satisfied part-time faculty.

The shift toward hiring more adjuncts and fewer tenure-track professors to teach has created a climate in which adjunct and non-tenure track faculty are now the majority in American colleges and universities. However, there has not been a comparable rise in compensation to match this increase in dependence on adjuncts (Gappa et al. 2007; Schuster \& Finkelstein, 2006). Part-time and adjunct faculty continue to be left out of shared governance, denied office space, omitted from group insurance and benefit packages, paid poorly, and given little status on their campuses (Conley et al., 2002; Gappa et al., 2007; Gappa \& Leslie, 1993; Leslie, 1998).

Many recent doctoral graduates searching for elusive tenure-track positions are discovering that they have become part of a growing contingent on campuses across the country - the adjunct professor. Some would argue that the extensive use of adjuncts in place of tenuretrack positions reflects a crisis in higher education. Fountain (2005) maintains that "leaders and administrators of higher learning are guilty of egregious moral and ethical breaches by exploiting adjunct faculty, students, and the general public in many ways" (p. 5). He also notes that: 
adjunct faculty have no formal standing in the institutions for which they teach, they are powerless---used and abused by a flawed system and are paid a third to a quarter of what a full-timer receives for teaching the same course(s), while teaching nearly half of all courses in higher education. (p. 6)

Largely unprotected against sudden termination of employment, part-time faculty members may avoid taking risks in the classroom or tackling controversial subjects. Vulnerable to student complaints and evaluations, adjunct faculty members may not feel free to teach rigorously, discuss controversial topics, make heavy reading assignments, or award low grades to those who deserve them. Fountain (2005) suggests that the veil of bureaucracy that universities hide behind should be removed in order to expose how they exploit these members of faculty. He also argues that it is "administrative incompetence and strategic bungling of administrators" (p. 22) that causes the exploitation of adjunct faculty.

\section{Statement of the Problem}

Part-time faculty members are increasingly hired for teaching in our colleges and universities. Often they are unclear as to the institutions' overall mission, purpose, and educational objectives. They may also be unclear of explicit expectations to conduct research, serve on committees, take on advisees, and write for professional publications. And, part-time faculty members are unclear as to whether they have a voice in academic governance and in the decision making processes that influence departmental policies and procedures. Gappa and Leslie (1993) and Lords (1999) suggest that despite performing a large share of instructional work, they are rewarded with short-term contracts; are paid by the hour or course; have limited or no benefits; and come and go through an open and revolving door. Part-time faculty members 
are disconnected from the mission and spirit of the institution (Gappa \& Leslie, 1993) and critics argue students suffer most.

Despite the crucial role that part-time faculty members play on college and university campuses, little is known about how their role is perceived by department chairs. Extant research and literature is largely from the perspective of central administrators (Roueche, Roueche, \& Milliron, 1995). Given the critical role that part-time faculty play in the nation's colleges and universities, which are experiencing changing student populations and major economic challenges, it seems appropriate to investigate a more current, comprehensive, and detailed account of how these faculty are perceived by department chairs in higher education institutions.

\section{Purpose of the Study}

The purpose of this study is to describe the status of adjunct faculty in Maryland public and private four-year colleges and universities as perceived by the department chairs and whether there are significant differences between private verses public institutions. In this study, the terms adjunct, part-time faculty, and contingent faculty are used interchangeably. The following research questions will be answered:

\section{Research Questions}

1. According to department chairs, to what extent is information collected on the professional commitments of their adjunct faculty? Is there a significant difference between public and private institutions in the perceptions of department chairs as to the extent information is collected on the professional commitments of their adjunct faculty?

2. According to department chairs, to what extent are adjunct faculty evaluated and what evidence is required? Is there a significant difference between public and private institutions in 
the perceptions of department chairs as to the extent adjunct faculty members are evaluated and evidence required?

3. According to department chairs, to what extent do adjunct faculty become integrated into the department? Is there a significant difference between public and private institutions in the perceptions of department chairs as to the extent adjunct faculty become integrated into the department?

4. According to department chairs, to what extent are performance expectations explained to adjunct faculty? Is there a significant difference between public and private institutions in the perceptions of department chairs as to the extent performance expectations are explained to adjunct faculty?

5. According to department chairs, to what extent are adjunct faculty satisfied with employment conditions in the department? Is there a significant difference between public and private institutions in the perceptions of department chairs as to the extent adjunct faculty members is satisfied with employment conditions in the department?

\section{Significance of Study}

While it is clear part-time and adjunct faculty provides benefits for institutions and administrators, it is unclear if adjunct and part-time faculty fully understand what the institution and department chairs expect of them. Many challenges arise for both policymakers and academics by increasing the use of part-time faculty and therefore research should not focus solely on numbers or percentages. Although beyond the scope of this research but worth noting, many institutions hire part-time faculty and gradually increase their teaching loads to what amounts to full-time status. However, they are not on the tenure track and therefore remain ineligible for tenure considerations. 
From an examination of the expectations of adjunct and part-time faculty as perceived by department chairs revealed in this study, perhaps we can better understand the role of adjunct and part-time faculty in higher education and find better strategies to integrate them into the campus culture. It is imperative to inquire from department chairs their perspectives for ensuring institutional effectiveness and integrity for continued reliance on part-time faculty in Maryland public and private four year colleges and universities.

\section{Definition of Terms}

For purposes of this study, the following definitions apply:

Adjunct Faculty, contingent faculty, and part-time faculty are used interchangeably. Adjunct faculty refers to those faculty members who work less than 35 hours per week at one institution, teach less than a full-time load and are employed on a semester-to-semester basis.

Adjunct Faculty Evaluations - A review of adjunct or part-time faculty performance normally conducted by the appropriate Associate Dean of Instruction, Department Chair or Assistant Chair. These evaluations usually consist of students rating their Instructors on a Likert scale. Employment Conditions - adjuncts with limited or no health insurance, no office space, no phone service, no say in university governance, etc.

Full-Time Faculty - those faculty, non-tenured or tenured, who are on the tenure track and enjoy full faculty status (National Education Association, 1987, p. 1).

Professional Commitments - adjuncts commitment to and outside the university setting. Status - One's position relative to that of others; standing; rank; and/or role.

\section{Summary}

The hiring of part-time faculty is increasing on college and university campuses. Adjunct faculty are shouldering a significant share-both in size and educational importance-of 
undergraduate teaching and are indispensable to the functioning of U.S. higher education institutions.

Given adjunct faculty anticipated use, little is known about the expectations that chairs have of them in terms of employment, evaluation, and aspects of their professional lives. If coming from the position that part-time faculty members are here to stay, thoroughly understanding their role is paramount to making them an integral part of the higher education institution.

\section{Organization of the Study}

Chapter One contains an introduction of the topic, the problem statement, purpose, significance, and rationale of the study. The remaining four chapters are organized as follows: Chapter Two begins by summarizing the relevant literature on part-time and adjunct faculty and their existing role within higher education. Chapter Three describes the research design employed in the study, and includes a description of the sample; the instruments used; data collection and analysis techniques; and limitations of the study. Chapter Four provides an analysis of the data and the results. Chapter Five provides a summary, conclusion, and recommendations for practice and recommendations subsequent research. 


\section{Chapter Two:}

\section{Overview}

\section{Review of the Literature}

The purpose of this literature review is to examine the body of research on part-time faculty in higher education. This chapter begins with a description of part-time faculty and their role in higher education. It also provides an overview as to why institutions continue to employee part-time faculty. The literature is geared specifically to address the research questions in the study.

\section{Defining Part-Time/Adjunct Faculty}

Part-time faculty have been a part of higher education for years and at one time enjoyed extremely high status. They were considered "experts," so valued for their specialized knowledge they were shared among institutions and were seen as prestigious outsiders who lent status and reputation to an institution. As the literature demonstrates, not all academia hold this view today. Many full-time faculty members are concerned that the quality of instruction will suffer if colleges and universities continue to hire more and more adjuncts instead of full-time professors. Adjunct faculty members also have legitimate concerns of their own-poor salaries, no health benefits, no job security, and the like.

Prior to 1980 the research on part-time faculty is scarce. In 1978, Tuckman conducted an in-depth study of part-time employment practices of postsecondary institutions. The taxonomy he developed is discussed briefly in this chapter, and his research is used as the basis of more recent research. More literature on part-time faculty became available in the 1980s and 1990s covering areas such as working conditions and needs, suggestions, and recommendations to improve their instructional competencies. 
Teaching part-time for a number of years can be seen in both a positive and negative light. Wallin (2004) notes that some potential employers may see the individual as flexible and able to perform in various venues with broad-based skills while others may see extended parttime work as a "red flag." The question arises if the person is really good, why has he or she not been able to land a full-time job? There must be something wrong. However, not all adjunct faculty members have the goal of becoming full-time faculty. In fact, the majority of adjunct faculty members hold other jobs that are usually full-time and not related to teaching. According to Leslie and Gappa (2002), only a small percentage (15-17\%) holds multiple part-time teaching positions. Use of part-time faculty, especially in community colleges, continues to grow because of financial concerns, expediency, and expertise - three main advantages to postsecondary institutions.

Foster and Foster (1998), who are usually very critical of part-time faculty use, suggest hiring part-time faculty provides benefits to the institutions where they work. They suggest that adjuncts and lecturers are of great benefit - by meeting institutional needs. Foster and Foster state that numerous instructors are "recent graduates who bring fresh ideas, conversation, and the latest news from graduate programs to the students and established professors" (p. 30). Also, they can be "excellent teachers, combining enthusiasm and an innovative spirit with a serious scholarly outlook" (p. 30). In many areas, practitioners may bring more real-world experience, along with "relevancy and excitement to the subjects being taught" (p. 31).

With the increasing use of part-time faculty, several studies have attempted to define and categorize them. These studies have focused on various aspects and characteristics of part-time faculty and include works by Tuckman (1978) and Biles and Tuckman (1986). Other areas of interest to scholars have been the political climate surrounding the increased use of part-time 
faculty (Gappa \& Leslie, 1997; Leslie, 1998), the characteristics of part-time faculty (Clery, 1998; Gappa \& Leslie, 1997; Mellander \& Mellander, 1999), and the quality of part-time faculty (Freeland, 1998; Gappa et al., 2007; Gappa \& Leslie, 1997; Green, 2007; Leslie, 1998; and Wallin, 2004).

\section{Tuckman's Taxonomy}

Tuckman (1978) interviewed 3,763 part-time instructors and created a taxonomy of seven, mutually-exclusive categories for part-timers:

Semiretireds $(2.8 \%$ of the total sample) - were former full-time academics/professionals who have reduced their hours and are no longer concerned about the future of their jobs/careers.

$>$ Graduate students (21.2\%) - were usually not employed at the institution where they were pursuing their degree and worked to augment income and gain experience.

$>$ Hopeful full-timers (16.6\%) - were those pursuing full-time academic positions but could not find them.

$>$ Full-mooners (27.6\%) - held primary jobs of at least thirty-five hours outside of academe.

$>$ Homeworkers $(6.4 \%)$ - worked part-time due to outside family commitments such as children or other relatives.

$>$ Part-mooners (13.6\%) - held part-time teaching positions while working less than thirtyfive hours a week elsewhere.

$>$ Part-unknowners $(11.8 \%)$ - were those whose reasons for working part-time were unknown, transitory or highly subjective (Tuckman, 1978).

\section{Biles and Tuckman's Taxonomy}


Biles and Tuckman (1986) utilized another typology that classified part-timers by their employment situation. The four classifications included the following:

Moonlighters - were employed in another job but taught one course. They had no fringe benefits, tenure, sabbatical leaves, advisees, committee work, or departmental vote on issues.

Twilighters - were not employed outside the institution, but the institution chose not to employ them full-time. They had no departmental vote but received prorated fringe benefits and longer contracts.

$>$ Sunlighters - were like full-time faculty in every aspect except the amount they work. They received prorated benefits, committee assignments, advisees, and tenure and sabbatical eligibility. Their probation period was a maximum of seventeen semesters, and they had an opportunity to negotiate full-time status.

$>$ Person on occasional part-time leave - were full-time faculty who may leave the institution or teach part-time for a short period of time. They may return to full-time status or continue in the part-time phase. This category included but not limited to women who had small children (pp. 11-13).

\section{Gappa and Leslie's Taxonomy}

Based on their 1993 study, Gappa and Leslie created four categories that encompassed and further defined Tuckman's taxonomy:

Career enders - included those in Tuckman's semiretired category as well as those who were already retired, and those moving to preretired or retired status. Many of these individuals were in well-established careers. 
Specialists, experts, and professionals - had primary careers elsewhere, usually full-time. These individuals worked part-time for the love of teaching with little concern about income.

Aspiring academics - were those who aspired to be "fully participating, recognized and rewarded members of the faculty with a status at least similar to that currently associated with the tenure-track or tenured faculty" (p. 48). Gappa and Leslie included part-time faculty who possessed a terminal degree and wanted full-time teaching careers and ABD doctoral candidates (students who had completed all the doctoral requirements except the dissertation). Also in this group, Gappa and Leslie distinguished between true part-time faculty and "full-time" part-timers that combined several part-time appointments at several institutions, sometimes teaching heavier loads than full-time faculty. This group was often referred to as "freeway fliers" (p. 48).

$>$ Freelancers - were a compilation of Tuckman's part-unknowners, part-mooners, and home workers. Part-time faculty members in this category were in higher education by choice and did not aspire to become academics.

Part-time faculty members are valued for their specialized knowledge because they bring "real-world" experience to students and significant economic benefits to the college or university (Banachowski, 1997). Cohen and Brawer (1996), for example, state that part-time faculty "may be more directly connected to the practical aspects of their work, and they may have a greater level of knowledge than most full-time faculty" (p. 87).

However, according to Foster and Foster (1998), this excellence is often lost because the adjunct's "struggle for survival provides strong incentive to relax standards in the hopes of getting good teaching evaluations" (p. 31), vital in retaining their current and future employment. 
Usually adjuncts are paid much less than permanent faculty, and, in most cases, they do not receive benefits, office space, or clerical support (Witt, Wattenbarger, Gollattscheck, \&

Suppiger, 1994). Not surprisingly, compensation for adjunct faculty remains a contentious issue.

Wallin (2004) argues that since part-time faculty teach the same students and the same basic material as full-time faculty, they should receive the same per class compensation as fulltime faculty. On the other hand she argues that:

In addition to classroom responsibilities, full-time faculty have committee assignments, office hours, student advising, and multiple preparations, as well as more experience in teaching than do part-time faculty. Thus, compensation must reflect the additional responsibilities of full-time faculty. (p. 380)

She contends the issue becomes even more complicated when benefits such as health insurance and retirement become part of the discussion.

\section{Advantages of Using Part-Time/Adjunct Faculty}

One of the most common reasons for using part-time faculty is cost (Banachowski, 1996a, 1996b; Gappa et al., 2007; Gappa \& Leslie, 1993; Haeger, 1998; Rifkin, 1998; Styne, 1997; Wallin, 2004). Part-time faculty members are "the economic bargain of the last 20 years" (Freeland, 1998, p.4). With the increasing fiscal constraints on institutional and departmental budgets, colleges and universities are seeking alternative methods of funding and cost cutting (Avakian, 1995; Monroe \& Denman, 1991; Osborn, 1990; Selvadurai, 1990). An institution can save a considerable amount of money by hiring adjuncts. Hiring part-time faculty is less costly because the pay scale is usually lower than full-time faculty, often set by course, and usually stagnant (Banachowski, 1996a, 1996b; Cohen \& Brawer, 1989; Gappa et al., 2007; Gappa \& Leslie, 1993; Twigg, 1989). 
Tucker (1984) also reported some potential advantages of part-time faculty and includes the following: hiring part-time faculty provides lower costs to the institution; fewer long-term commitments by the institution generally; and part-time faculty have a positive attitude and are usually up-to-date in their fields. Part-time faculty can also constitute a candidate pool when a full-time opening occurs, may have a better understanding of part-time students and can provide a link with the larger community.

In addition, Mangan (1991) discussed the savings in terms of sick leave, pension, and health-care insurance that institutions secure from use of part-time faculty. Another key benefit of using part-time faculty is flexibility (Gappa \& Leslie, 1993; Rhodes, 1996). One of the greatest advantages of flexibility is the ability to quickly adapt to varying enrollment demands (Lankard, 1993; McGuire, 1993; Osborn, 1990). Utilizing part-time faculty allows departments to hire, often on very short notice, if there is a greater demand for classes than expected (Cohen \& Brawer, 1989; Mize, 1998).

The use of adjuncts also provides for more flexibility in meeting institutions' needs such as flexibility in class scheduling (AAUP, 1998). This is a significant issue in community colleges because there is often a large population of part-time students that affects enrollment. In addition, budgets are often based on formulas that use enrollments from as many as three years preceding the current academic year (Gappa \& Leslie, 1993). These formulas do not accommodate any fluctuations in enrollments and can lead to significant budget crises in many departments with surging enrollments. Use of part-time faculty provides the needed flexibility in these situations and the cost-effectiveness of part-time faculty allows departments to make the best use of limited resources. 
Also, using adjuncts for introductory classes allows full-time faculty to teach advanced level courses and work on research projects (AAUP, 1998; Mize, 1998). Replacing full-time faculty with adjuncts can result in department cost savings (Gappa \& Leslie, 1993; Haeger, 1998). Part-time faculty are more willing to teach at odd times and in different locations (Cohen \& Brawer, 1989) providing inexpensive and mobile labor (Clark, 1997), which increases departmental flexibility. In addition, some institutions have branch campuses, and using parttime faculty allows colleges to offer classes away from the main campus and utilize expertise from the area where the branch campus is located (Lee, 1997). Farrell (1992) and Balch (1999) discussed the use of part-time faculty to test and evaluate new curriculum without burdening fulltime faculty. Institutions can limit their costs significantly from this form of curriculum development (Balch, 1999; Roueche et al., 1995).

Due to changing enrollment demands, institutions enjoy flexibility because of the temporary nature of adjunct contracts (McGuire cited in Banachowski, 1997). Adjuncts also contribute "depth, breadth and relevance" to the curriculum, according to McGuire cited in McArthur (1999), enabling institutions to provide courses that might otherwise be unavailable. And, as previously mentioned, adjuncts working in their fields inject a "real world" perspective into the institution's programs.

Part-time faculty also benefit from their college employment in various ways, depending on their reasons for teaching. Those employed outside of the teaching profession find that their college and/or university experience benefited their careers, while those who aspire to teaching full-time see part-time work as a step towards their goal (Silvers cited in Banachowski, 1997). As Cohen and Brawer (1996) note, this "arrangement also works for those free-lance teachers who work when and where the jobs are available" (p. 87). 
One of the main benefits of part-time faculty is that they provide diverse and specialized skills, often working full-time within the field of study (Banachowski, 1996a, 1996b; Gappa \& Leslie, 1993; Haeger, 1998; Lee, 1997; Mize, 1998). These instructors provide up-to-date real world experience and skills (Cline, 1993; Cohen, 1992; Cohen \& Brawer, 1989; Littrell, 1990; Roueche et al., 1995) and infuse a field's professional norms and values into the curriculum (Phelan, 1986).

Finally, adjunct faculty members, especially those working full-time in professional positions, help the transition of students into the real world work force and provide valuable contacts (AAUP, 1998; Gappa \& Leslie, 1993; Roueche et al., 1995). Often, part-time faculty members provide a pool of talented, motivated teachers (McGuire, 1993). Using older faculty who are retired or semi-retired also has its benefits. These individuals can teach part-time allowing them to remain a part of the institution as well as providing expertise and continuity (Gappa \& Leslie, 1993; Lee, 1997).

\section{Disadvantages of Using Part-Time/Adjunct Faculty}

Although there are many benefits of using adjunct faculty to meet educational needs, the literature also cites real, perceived, and potential problems with using part-time faculty. With more part-time faculty, there is the belief that the quality of programs may be affected because these individuals may not be able or want to participate in, or even be concerned with, institutional activities such as inter/intra-departmental collegiality, governance, course content, curriculum development, faculty-student interaction, and student advising (Gappa \& Leslie, 1993; Haeger, 1998; Lee, 1997; Roueche et al., 1995).

Among the many concerns regarding adjunct faculty, lower quality of instruction is one that full-time faculty are concerned about. As documented by Leatherman (1997) "lecturers are 
more likely to give higher grades because their positions are so dependent on good student evaluations" (p. A-13). This practice could lead to a lower quality of instruction. Foster \& Foster (1998) pose two questions that sum up these concerns succinctly: 1) What is the effect of many part-time professors "on the quality of the education a college or university can offer?" and 2) "What are the consequences for the long-term health of the institution?" (p. 30). Their experiences suggest the answer to both questions is "deleterious (harmful; destructive) [italics added] on both counts" (p. 30). Foster and Foster agree that adjunct faculty cannot assume responsibility for full academic development of their students. They state that "it is not the temporary professors who are to blame, but the terms of their employment, which weaken their ability to foster excellence and to become genuinely involved with students" (p. 32). Their preoccupation with seeking full-time work and insecurity about their teaching skills makes it difficult to defend their academic standards (Kronberg, 2004).

Not surprising, administration officials view the continued hiring of adjuncts as an effective way to cut costs because they pay a minimal salary with no benefits. Thompson (1992a) for example, suggests that using many part-time faculty is a way to cut expenses and costs, but with another motive. She suggests the use of part-timers to be "a broader business strategy to minimize pay and maximize control" (p. 22). The use and abuse of part-timers could suggest that “insecurity also breeds fear of reprisal, further reducing union involvement of people" (p. 24). Therefore, "this would lead to divided faculties, limited bargaining power, and less effective faculty governance" (Kronberg, 2004, p. 21). Rhoades (1996) suggests that most of the "problems experienced by part-timers are attributed to full-time faculty more interested in protecting their professional privilege than in educational quality or employment quality" (p. 627). 
Often, due to some emergency, adjuncts are hired at the last minute or to meet a particular area of growth. Rifkin (2000) suggests they may be unfamiliar with ordering textbooks, uncomfortable preparing syllabi, not have the expertise to conduct group work or class discussions, thus, the quality of instruction may suffer. Also, due to being employed elsewhere, adjuncts may not have the commitment to the college or university that is more typical of full-time faculty.

An additional study conducted by Bolge (1995) focused exclusively on the community college and the effectiveness of its part-time faculty. Bolge's study measured the amount of learning by the students relative to the status of the instructor (full-time versus part-time). Bolge found no significant difference between the scores of students relative to the different categories of faculty. He concluded that "students taught by full-time faculty fared no better in posttest scores (final grades) than students taught by part-time faculty" (p. 3). This study's focus was only upon remedial mathematics courses and therefore one could argue it had limited application and results. Bolge recommended "continuing the practice of employing part-time faculty," and he "suggested more research on part-time faculty" (p. 3) since he found very little previous research on the topic.

Relationships of the part-timer relative to other faculty members, especially full-time, were an additional topic of concern. Lundy and Warne (1990), interviewed part-time faculty and of those, $58 \%$ stated they were dissatisfied with their status as part-time employees. Patronizing attitudes and arrogance towards adjuncts appeared to occur regularly. Some adjuncts cited "the shameless arrogance of the aristocracy of the ancient regime, especially those who talk most loudly of their sympathy for the oppressed" (p. 216). One adjunct stated in Lundy and Warne's study "what bothers me most is the way most full-timers treat me and other part-timers as if we 
were a lower form of life" (p. 219). Establishing any kind of relationships either with other faculty or the institution is unlikely for adjuncts, knowing such animosity exists. Lundy and Warne's study corresponds with Gappa and Leslie's (1993) study, finding two distinct castes of faculty members.

\section{Effects on Full-time Faculty}

A 1988 Commission On The Future Of Community Colleges stated that "within the next 12 years, approximately $40 \%$ of all community college faculty who now teach will retire" (Banachowski, 1996b, p. 7) with many of these positions being filled by part-time faculty (Mangan, 1991). With the increasing use of part-time faculty, decreasing number of full-time positions, and extra pay for course overloads, there may be a harmful effect on full-time faculty (Gappa \& Leslie, 1993; Twigg, 1989). Another significant impact from the overuse of part-time faculty is that it may create a "false economy" (Gappa \& Leslie, 1993). Although economical savings from the use of part-time faculty may be perceived, the cost to faculty within departments may be significant with increased responsibilities to full-time faculty in areas such as advising, curriculum development, and program coordination (AAUP, 1998; Gappa \& Leslie, 1993; Mize, 1998; Styne, 1997). Furthermore, the savings may be offset by lack of program coherence, reduced faculty involvement with students, and reduced student learning (AAUP, 1998). An additional "hidden cost" of using part-time faculty is the growing costs of unemployment benefits to institutions (Nance \& Culverhouse, 1991-1992). Many states require only a short period of work time to qualify for unemployment, and part-time faculty are utilizing this system to compensate for breaks in their employment. Interestingly, Nance and Culverhouse note that most deans and department chairs are usually unaware of this problem. 


\section{Professionalism of Faculty}

With part-time faculty numbers growing in community colleges, there is the potential for community college faculties to become predominantly part-time (Lee, 1997). Clark (1988) believed that the use of part-time faculty would affect the professionalism of the institution's faculty, claiming that using adjuncts is "a disaster for the professorate... Nothing deprofessionalizes an occupation faster and more thoroughly than the transformation of full-time posts into part-time labor" (p. 9). In addition, Clark (1997) noted that part-time faculty members have long been in marginalized positions, with little influence over decisions and little opportunity to be an active member of the collegiate environment. Overuse of part-time faculty lessens opportunities for academic professionals and may lead to lower salaries for entering, fulltime, tenure-track faculty, further leading to diminished quality of faculty recruits in undergraduate education (AAUP, 1998).

\section{Quality of Teaching}

Another concern for the institution is the quality of teaching provided by adjuncts. The belief by many in academe is that the quality of part-time faculty is not as good as full-time faculty (Mize, 1998). German's (1996) survey of full-time faculty showed that $80 \%$ believed that use of adjunct faculty had a negative effect on academic excellence. Lankard (1993) noted that many part-time faculty members are hired for their professional abilities and expertise but may have little training in teaching skills. There are studies that support this notion, according to Digranes and Digranes (1995), noting that many part-time faculty members fail to incorporate new teaching methods in their courses. In a single site case study, Spangler's (1990) study of reading and writing examinations at Los Angeles Valley College indicated that students of part- 
time faculty did not score as well as students of full-time faculty (Banachowski, 1996a, 1996b; Mize, 1997).

However, there are studies that challenge these notions. For example, several studies found little to no difference between full-time and part-time faculty when focusing on the following aspects: instruction (Bolge, 1995; Sworder, 1987), student success rates (Bolge, 1995; Iadevaia, 1991) student performance based on grade differentiation (Stovall, 1994, cited in Banachowski, 1996a), students' post-test scores (Bolge, 1995), when there was a control for discipline (Lowther et al., 1990, cited in Banachowski, 1996), or in overall quality of instruction (Roueche et al., 1995).

Burgess and Samuel (1999) found that when studying retention and academic performance for either developmental or regular courses, students who took a first course in a two course series from an adjunct instructor and the second course from a full-time instructor seemed under prepared for the second course.

Also, the AAUP (1998) believes that excessive use of and reliance on part-time faculty in lower-level courses may lead to a decline in quality of upper levels of undergraduate instruction. MacFarland's (1998) study on grades awarded by part- and full-time faculty found that adjunct faculty awarded higher grades than full-time faculty. This study agreed with Fedler's (1989) research that supported the opinion that part-time faculty members are not as difficult or demanding on students as full-time faculty. Fedler compared students' grades and found that part-time faculty awarded higher grades than full-time faculty in all three institutions studied. Are part-time instructors easier or are they more effective in helping students meet learning objectives? If they are more effective, more research on full-time faculty's teaching skills is needed (Banachowski, 1996a). 
Rifkin (1998) surveyed 1,554 faculty members at community colleges around the country and found that part-time faculty had greater expectations for student learning and achievement than full-time faculty. This seems to contrast with the popular notion that part-time faculty have lower expectations of students. Rifkin believed that this refutes previous findings that part-time faculty inflate grades (Fedler, 1989) or undermine instructional quality (Thompson, 1992b). There are several studies that show that part- and full-time faculty use similar instructional methods (Kelly, 1991; Impara, Hoerner, Clowes, \& Alkins, 1991).

In addition, Rhodes (1996) found that part-time faculty, including department heads, rated similarly on teaching priorities in determining course goals, using a variety of teaching methods, and clearly defining performance objectives as high priorities. The AAUP (1998) discussed a study using a single course, section by section review that found the quality of partand full-time instructors were equivalent with the same measures as Rhodes. Bogg's study of freshmen at Butte College found no difference in students' performances based on having a partor full-time instructor (cited in Banachowski, 1996a).

\section{Impact on Students}

There also are disadvantages that impact students when using adjunct faculty. Adjuncts are less likely to have offices or hold office hours, which leads to fewer interactions with students (AAUP, 1998; Balch, 1999; Brewer \& Gray, 2000; Elman, 2003; Mize, 1998; Weglarz, 1998). Students may hesitant to take classes from adjunct instructors because they are concerned they may not get the full value of their tuition money because of inferior teaching ability. "The students don't pay any less (tuition) when they are taught by a part-time instructor" (Finucane \& Algren, 1997, p. 44). Also, students find that part-time faculty members teach many core classes 
that create the foundation for their studies, possibly leaving them at a disadvantage (AAUP, 1998) if the courses are not taught well.

\section{Professional Commitments of Part-Time/Adjunct Faculty}

The literature on part-time faculty's professional commitment outside the classroom is limited at best. In general, part-time faculty members are hired to teach specific courses for a specific time period. Department chairs typically do most of the hiring (Christensen, 2008); therefore their focus is on what adjuncts bring into the teaching environment, not so much their role as a "professional educator." It is helpful and even necessary for department chairs to know something about their prospective hires, but only to the extent of their expertise in a particular field. Beyond the basic information needed for hire, department chairs do not collect significant amounts of data on part-time faculty prior to teaching. Typically, other parts of the institution are responsible for aspects of the hiring process, not department chairs. For example, the institution usually conducts a background investigation on prospective hires.

Part-time faculty members are generally recruited from several sources. In the early days of community colleges, most part-time faculty members were secondary school instructors and some university professors. By the mid 1970s, part-time faculty included many retired individuals and graduate students (Cohen \& Brawer, 1989). There are many issues to consider when recruiting and hiring adjunct faculty. Adjuncts are often treated as transient or temporary workers with selection often resulting in last minute, one-semester hirings by the institutions (Finucane \& Algren, 1997; Gappa \& Leslie, 1993). Often, recruitment efforts for part-time faculty are by word of mouth, internally, or only advertised locally, possibly regionally (Gappa, 2000). Some institutions do not have a set hiring policy or contract. Hiring processes often lack any set procedures, and as Gappa noted "[b]ottom-fishing for the least expensive and most 
vulnerable (but not necessarily best qualified) can occur when department chairs are not accountable for their hiring practices" (p. 80). Also, appointments are often given late and are on a term-by-term basis.

This is emphasized by Rhodes' (1996) study of contracts for part-time faculty. Of 183 contracts analyzed, the appointment and release of part-time faculty was not specified in 140 . There are other problems encountered by institutions when hiring part-time faculty. In some states, union contracts allow last minute bumps by full-time faculty, and this uncertainty of employment makes qualified adjuncts hard to find and keep. Also, students may be hesitant to register for classes marked as "staff" or "TBA" because they do not know who will be teaching these specific courses. It is often difficult to find adjuncts to teach at specific time's full-time faculty do not want, such as early morning or weekend classes. Styne (1997) notes that loss of adjuncts to last minute reasons, such as illness, death, or no-shows, makes recruitment especially difficult. The actual hiring process is another issue in recruitment. The AAUP (1998) stated that the full-time faculty hiring process was much more stringent than for part-time faculty. Growing use of long-term part-time faculty may require a more efficient hiring process of adjuncts, making it as important as the hiring of full-time instructors (Balch, 1999; Roueche et al., 1995). Evaluation of Part-Time/Adjunct Faculty

The AAUP (1998) noted that adjunct faculty members are much less likely than full-time faculty to receive any type of evaluations. Institutions, however, are beginning to establish policies for formal evaluation of adjuncts (Baron-Nixon, 2007; Parsons, 1998; Styne, 1997). Part of the reason for formal policies being developed is the demand from "the customers" to know they are receiving quality instruction (Williams, 1994). There are several types of evaluations that may be used by institutions. From his case study of Yavapai College, Williams analyzed the 
three forms of evaluation the institutions incorporated for part-time faculty evaluation: standardized student evaluations, administrative in-class evaluations, and self-analysis evaluations. Student evaluations are the most common form of evaluation. These evaluations are usually standardized forms filled out on a periodic basis, usually once per term, and for many part-time faculty members, these evaluations are the only form of feedback they receive. In the assessment of use of student evaluations at Yavapai College, it was determined that students were very honest in their evaluation of instructors and the courses (Williams, 1994).

Some institutions have administrators or full-time faculty visit classrooms and provide formal and informal feedback. In a case study of her department, Styne (1997) discussed how new instructors have experienced instructors visit the classroom in the first and second semester of teaching. Feedback on ways to improve in the classroom is then provided to the new adjuncts. This has proven to be successful and much appreciated by new adjuncts. In their study of community, technical, and junior colleges in a 19-state region, Erwin \& Andrews (1993) found that $88.6 \%$ of the institutions had evaluation procedures in place for part-time faculty compared to $97.5 \%$ for full-time faculty. In sum, of the part-time faculty evaluated in Erwin \& Andrews study, $60 \%$ were not satisfied with the evaluation system.

Evaluation plays a significant role in faculty integration into an institution (Behrendt \& Parsons, 1983). "Faculty evaluation should be used as a tool to seek more overlap among credit/noncredit and full-time/part-time teaching staff members so that ....artificial barriers are removed" (p. 42), and part-time faculty feel as though they are an integral part of the institution.

\section{Evaluation through Professional Development}


Marits (1996) discussed the benefits to colleges that provide professional development opportunities to adjuncts. First, it contributes to better integration of part-time faculty into institutional goals. Secondly, it is an excellent recruiting tool to attract outstanding adjuncts.

Professional development provides an organized plan for assessing faculty growth and development (Marits, 1996). Furthermore, Balch (1999) noted that all activities involving parttime faculty help to improve instructional abilities. Interestingly, Rhodes' (1996) study of parttime faculty contracts showed that only 10 of 183 made any provisions for professional development.

Finucane and Algren's (1997) study found that part-time faculty believed that the lack of professional development leads to decreased quality of classroom instruction and could possibly affect individual adjunct's career development. Kelly (1991) found that part-time faculty members were very interested in professional development, especially concerning areas closely tied to teaching. Instructional topics of greatest interest to part-time faculty included motivational techniques for the classroom, teaching underprepared and adult students, and increasing student retention (p. 11). Finally, Baron-Nixon (2007) and Pollington (1991) found that part-time faculty wanted to be involved in areas of professional development as well as provided with opportunities to conduct research. Unfortunately, part-time faculty members were much less likely than full-time faculty to receive any form of professional development (AAUP, 1998; Baron-Nixon, 2007).

\section{Integration of Part-Time/Adjunct Faculty into the Department}

Huffman (1997) noted additional barriers affecting adjunct professors that included time and distance. The logistics of full-time employment, geographical location, and psychological separation, affects the interaction of part-time faculty with the employer supporting institution. 
Van Maanen (1976) and Van Maanen and Schein (1979) defined socialization as the progression of learning the culture, norms, and expectations of the workplace. Thompson and Hickey (2005) defines socialization as a process by which society learns and internalizes the attitudes, values, beliefs, and norms of our culture and develop a sense of self.

Integration of adjunct faculty is critical to higher education institutions as it has been linked to variables such as satisfaction, feelings of self-worth, effective performance, productivity, role clarity and performance, and commitment (Algren, 1997). Most institutions do a poor job of integrating part-time faculty into the institutional culture, with few administrations aggressively or systematically directing integration efforts (AAUP, 1998; Balch, 1999; BaronNixon, 2007; Parsons, 1998; Roueche et al., 1995, 1996a, 1996b).

In addition, lack of integration in department programs often leads to feelings of exclusion and isolation and decreasing job satisfaction (Balch, 1999; Baron-Nixon, 2007; Finucane \& Algren, 1997; Rifkin, 1998). Roueche et al. (1996a, 1996b) suggests that integration of part-time faculty into department programs is vital not only for the department but the institution as well. Roueche et al. (1996a) also stated that "part-time faculty members are a vital resource that can and should be integrated into the community of learners" (p. 45).

Finucane \& Algren (1997) suggest two ways to socialize or integrate adjunct faculty, through formal and informal methods. Examples of formal integration are orientation for new adjuncts where department programs, institutional policies and procedures are explained, documents such as handbooks, rules, benefit booklets, and employee services information that provide much needed information, mentoring programs for new instructors, and professional development opportunities (Balch, 1999; Finucane \& Algren). 
Informal socialization is on the job learning (Jones, 1986) and often comes from experiences and interactions (Jablin, 1987). German (1996) believed that "the challenge of the future is to integrate part-time faculty, tapping their talents and energies, while providing them with collegial support and positive relationships to the institutions" (p. 239). To improve integration, one must understand how important the part-time faculty's loyalty is to the department first, then to the institution, and why the departments should make efforts to regularly integrate adjuncts with full-time faculty (Balch, 1999; Gappa \& Leslie, 1993).

Thompson (1995) stated, "the most successful adjunct development programs are those that have the commitment and participation of the college administration and full and part-time faculty to help integrate adjuncts into the mainstream of the college" (pp. 19-20). This can be done in a variety of ways. One of the most important ways to do this is to include them in the academic decision-making process.

According to Kelly (1991) part-time faculty often feel as if they are second-class citizens in the academic community and are usually excluded from the decision making process. Most part-time faculty do not attend meetings at the departmental or institutional level or serve on committees, but research indicates many would like to be included (Baron-Nixon, 2007; Kelly, 1991; Pollington, 1991). Kelly’s study found that some part-time faculty members were invited to faculty meetings, but most of those that were invited could not attend because of scheduling conflicts. She also found that part-timers who attended division meetings felt more involved in the campus community. In addition, Rifkin (1998) found that part-timers had little autonomy within institutions because they had no decision-making power. In a study of part-time faculty, Sheeks (1998) concluded that there was a lack of consistency in the recruitment, utilization, integration, and socialization of part-time faculty. Roueche, et al. (1995) discussed these issues 
as ones administrators found important when discussing part-time faculty, specifically recruitment and hiring, socialization and integration, compensation and benefits, job security, and evaluation of part-time faculty.

\section{Performance Expectations of Part-Time/Adjunct Faculty}

Adjunct faculty, while non-tenure track, contribute significantly to the quality of the teaching-learning process. As noted by Christensen (2008), part-time/adjuncts should check with their chair upon appointment for specific requirements outlined by the department regarding such issues as course content expectations, student evaluations, student advisements, office hours, faculty meetings, course evaluations, etc.

Scheduling office hours is typically required by each department, according to full-time or part-time appointment expectations (Baron-Nixon, 2007; Gappa et al., 2007). Full-time faculty members are generally expected to schedule office hours twice a week. Parttime/adjuncts typically hold office hours before or after their scheduled class times. Generally speaking, adjuncts teaching one course are not expected to advise students. However, those parttime faculty members teaching more than one course are expected to participate in students advising. Pisani and Stott (1998) argue that the use of adjuncts erodes the quality of student advising. They also suggest that part-time faculty increase the distribution of other departmental tasks, such as committee work, for regular full-time faculty.

\section{Employment Conditions of Part-Time/Adjunct Faculty}

The current literature on part-time faculty in the community colleges has much to say about employment conditions and the reasons why they are so unattractive to adjunct faculty. The first big issue is salary and benefits, as one adjunct state "I am angry at my salary because it is a recognition of my worth ..... I need recognition and appreciation. The institution is ... 
embarrassed because they don't pay well” (Gappa \& Leslie, 1993, p. 107). Full-time faculty who know of the generally substandard working conditions and compensation of adjuncts may doubt their part-time colleague's degree of commitment to students (Gappa \& Leslie, 1993).

Weglarz's (1998) study found that $90 \%$ of part-time faculty ranked salary as the first or second choice of importance. As previously noted, compensation varies widely among institutions, and it is far below the full-time faculty equivalent. Some institutions pay a flat fee per course (e.g., Frostburg State University Faculty Handbook, 2008); other institutions have a salary range based on experience (Balch, 1999; Gappa, 2000). Part-time faculty members are confronted with low and static pay scales (Banachowski, 1996a, 1996b; Fountain, 2005; Fulton, 2000; Gappa, 2000; Gappa \& Leslie, 1993; Kelly, 1991; Lankard, 1993; Pollington, 1991, 1992; Twigg, 1989; Wyles, 1998) and a median pay of $\$ 1,500$ for a three-credit course (Avakian, 1995; Wyles, 1998). Grenzke (1998) found that approximately one-half of adjunct faculty earns $\$ 2,500$ per course.

Salaries can range from $\$ 1,000$ to $\$ 3,500$ per course; a fraction of the full-time faculty pay (AAUP, 1998; Baron-Nixon, 2007; Gappa \& Leslie, 1993; Kelly, 1991; Pollington, 1991; Roueche et al., 1995). Roueche et al.'s (1995) study of community colleges indicated a mean salary of $\$ 1,197$ with a range of $\$ 424$ to $\$ 3,852$ per course. Conley et al. (2002) found that the average basic salary for part-time faculty was $\$ 10,200$, which constituted only about $30 \%$ of their income; the other $70 \%$ came from outside sources.

The discrepancy between the salary of full-time and part-time faculty is a concern. Roueche et al. (1995) found that the average expense for a community college district for 10 three-hour courses for a new, full-time entry-level faculty member was $\$ 38,225$; the same district could use part-time faculty to teach those 10 classes and save approximately $\$ 21,400$ (p. 35). In 
California, hourly rates for part-timers may be from $1 / 3$ to $1 / 2$ of full-time faculty's rates. Thompson (1992a) stated, "Part-timers who calculate their actual hourly wages based on time spent teaching, preparing, and grading sometimes learn that they are earning less than the minimum wage" (p. 30). There may also be disparity of pay within states. Spinetta (1990) found a variation of as much as $350 \%$ in compensation level of part-time faculty within the 107 California community colleges. As Pollington (1991) noted, part-time faculty would like to be paid fairly for the work they do.

The 1993 NSOPF found that 55\% of part-time faculty members were satisfied overall with their pay, but only $43 \%$ were satisfied with their benefits. Lack of benefits is also a concern for adjunct faculty (Kelly, 1991; Mize, 1998; Pollington, 1991). There are limited, if any, benefits such as health insurance and retirement (AAUP, 1998; Balch, 1999; Banachowski, 1996a, 1996b; Fountain, 2005; Fulton, 2000; Gappa \& Leslie, 1993; Lankard, 1993; Pollington, 1991, 1992; Roueche et al., 1995). Some institutions provide a medical benefits plan, if the instructor is considered half-time, non-tenured and, if provided at all, retirement benefits vary widely among institutions (e.g., Frostburg State University Faculty Handbook, 2008).

Balch (1999) pointed out that offering benefits can be very costly and institutions may need to look at other options. With part-timers much less likely to receive any fringe benefits, Balch anticipated that there may be a significant social implication in the future with many of these individuals relying on the government for emergencies and retirement. Pollington (1991) also found that part-time faculty members were not eligible for other benefits as well. Tuition waivers are often a benefit for full-time faculty and staff but are not given to part-timers even when they teach close to a full-load and have been an employee for several years. She also noted that part-time faculty members do not receive the same treatment as full-time faculty with 
respect to library privileges, parking permits, newsletters, and names published in the class schedule.

Often, part-time faculty “experience ambivalence, conflict and frustration about the circumstances under which they are forced to deliver instruction" (Jacobs, 1998, p. 14). Fulton (2000), a college administrator, makes a similar assertion when he writes that while the current adjunct situation is "unethical and unhealthy," the colleges and the part-timers share the blame for "pretending either that one can live on a collection of part-timer's stipends, or that no one is really trying to do so" (p. 43). He calls on both parties to admit that "part-time positions are not now, nor were they ever, meant to be pieces of full-time positions" (p. 43).

It is probably fair to say that filling in staffing gaps with adjuncts is standard practice in colleges and universities. One could argue this may be another instance of quality being sacrificed for budget savings because program continuity suffers when many different instructors share a full course load, and even smaller portions of an entire curriculum (Banachowski cited in McArthur, 1999). Still, departments do need replacements from time to time, i.e., when full-time professors are on leave, when no full-time professors with a particular expertise are available and, perhaps most importantly, when enrollment exceeds projections (Jacobs, 1998). This last circumstance can occur beyond the institution's control. "External factors, such as the economy, the availability of financial aid, and changes in the job market affecting program popularity and student demand for courses, all contribute to enrollment fluctuations” (Jacobs, p. 12).

The literature clearly documents the less than adequate conditions under which many adjuncts are employed, contributing to their marginalization as a kind of academic underclass. Kurzet (1997) asserts that it is not unusual to find college departments where the full-time professors do not know all the names of their part-time colleagues. Gappa and Leslie (1993) 
encountered full-time faculty who view adjuncts as "laboring drones who supposedly detract from the quality of education" (p. 17). In reality, however, Gappa and Leslie report that part-time instructors tend to be "exceptionally well qualified for their assignments" (p. 18).

A vital concern of part-time faculty members is that they often are hired with little or no lead time for course preparation. This obviously creates a less than ideal situation for achieving appropriate interaction with colleagues regarding curriculum, current changes in program, etc. Part-time faculty have often been referenced as contingent workers (R. A. Hartnett, personal communication, April 15, 2006) who move on when enrollment declines or are called in when enrollment increases unexpectedly.

Few colleges or universities offer benefits to part-time faculty, though that is changing some with increasing unionization on some campuses and in some states. Administrators are constantly seeking to balance increased compensation and benefits for all faculty members with the realities of supply and demand in a time of budget cutbacks and reduced state and local financial support.

Greive and Worden (2000) point out that in such an environment the possibilities for exploitation of part-time faculty is likely. Administrators and full-time faculty frequently perceive part-time faculty to be outside of the mainstream due in large part to their short-term contracts with low wages and no job security. Thus:

Adjunct and part-time faculty have relatively little power in the institution and are vulnerable to exploitation and mistreatment from unscrupulous college administrators .... Their limited power, desire for full-time appointments, or commitment to another full-time profession result in their reluctance to seek redress for administrative mistreatment, even when it is egregious. (p. 102) 
Tuckman and Tuckman (1981) examine the problem of compensation in another way. They recognize that part-time faculty salaries often remain static while full-time salaries increase. Once part-time faculty members negotiate their salary it usually remains the same for several years. At least two consequences result. First, persons relying on a "part-time job as a primary source of earning fall behind the rest of the labor market," (p. 5) giving rise to frustration, discontent, and turnover among part-timers. Second, the growing disparity between part time-and full-time salaries creates an incentive for institutions to hire more part-timers, creating an "incentive to reduce the number of full-time openings" (p. 5).

According to research by Gappa (1984), part-time faculty members are paid $25-35 \%$ less than full-time faculty. She maintains that these differences are not so much the result of differences in qualifications as differences based on institutional policies and market conditions. According to Wallin (2004), the compensation issues are further exacerbated by the fact that adjunct faculty usually do not receive salary increases commensurate with their length of service, as is common with full-time faculty. Thus, over time, adjuncts fall even further behind their fulltime counterparts.

Gappa and Leslie (1997) conclude from their studies that:

Part-timers and full-timers are similar in their characteristics, but [that] they have very different working conditions. The existence of two separate and distinct employment systems has the potential to damage academic quality ... part-time faculty constitute a well-qualified, valuable resource and, when properly used, contribute significantly to academic quality. (p. 1)

German (1996) predicted part-time faculty will dominate higher education in the future and this idea is supported by several arguments and practices. For example, adjunct faculty can 
be useful in "enhancing programmatic richness" (Sayer, 1999, p. 102). Similarly, in professionally-oriented fields such as media or public relations, practitioners see the hiring of adjuncts as a strength of programs (Blanchard \& Christ, 1993).

Even though part-time faculty members are being accepted on an increasing basis, a review of the literature makes it clear they are less than satisfied because they are not accorded the same consideration or support as other faculty members and they are under appreciated (Townsend, 2000). Still the working conditions and status of part-time faculty are increasingly issues of concern within higher education. Sayer (1999) noted that the "typical adjunct is horribly overworked, horribly underpaid, and totally unappreciated" (p. 102).

At Prince Georges Community College in Maryland a study was conducted that speaks to the desires of part-time faculty (Cohen, 1992). Part-time faculty members, especially those who are long term, desire a greater sense of institutional belonging and a better orientation to institutional policies. Based on the data from the surveys, the college made several changes to address the concerns of the part-time faculty by: (a) increasing pay based on length of service; (b) listing senior part-time faculty in the college catalog; (c) holding faculty orientation sessions each term; (d) offering more faculty development workshops; (e) creating a handbook for adjunct faculty; and (f) honoring an outstanding adjunct each year (Cohen, 1992).

Tucker (1984) identified some institutional problems associated with the use of part-time faculty. Potential problems include: wages of part-time faculty are exploited; lack of continuity in academic programs and curriculum; part-time faculty are often not required to hold office hours; a perception that part-time faculty may not fully prepare for their courses; and generally, no expectation that part-time faculty will participate in committee work, curricular development and governance. 
Gappa (1984) suggests there is little or no employment security for part-time faculty. “. . . part-timers have long known that the primary feature of their status in higher education is their expendability" (p. 6). In larger urban settings, where there is a large pool of qualified candidates, part-timers find the competition for part-time positions adds to the insecurity. The law in most, if not all institutions, holds that part-time faculty members have no claim to their jobs and may be removed and/or replaced at will. Administrative policies in higher education reinforce this doctrine. Legal action to force equal pay for equal work for part-time faculty has been unsuccessful because they are seen as doing different types of work than are their full-time colleagues. Biles and Tuckman (1986) and Fountain (2005) argue that there is a need to balance the institutional need for flexibility with standards of fairness and equity for part-timers.

Part-time faculty members do not take part in the governance of the institution. Fountain (2005), an administrator himself, takes issue with this because of the belief that schools of higher education should be reasonably democratic institutions. There is little academic kinship between part-time and full-time faculty because part-timers do not participate in departmental or institutional life. The concerns of adjuncts are more directed toward adequate pay, guarantees of continuing work, preference for full-time work, and more respect. Part-time faculty members are generally satisfied with many aspects of their jobs, such as teaching, but dissatisfied with the low salary, little or no benefits, and not being included in decision-making (Fountain, 2005; Gappa \& Leslie, 1993, 1997). The image of part-timers varies according to the circumstances that lead to their hiring. They may be viewed as a valued resource or as an accommodation to fiscal necessity. Full-time faculty see the benefits incurred when part-time faculty "are regarded as pivotal in meeting pedagogical objectives" (Warme \& Lundy, 1988, pp. 207-208). When cost is a major reason for the use of part-timers, the situation is seen negatively. 
Part-time faculty members often feel a sense of disconnect from the institution's mission and spirit according to Gappa and Leslie (1993). The university has no commitment to parttimers and part-timers are "less apt to have a long-term commitment to the university" (Wilson, 1996, p. A-13).

Avakian (1995) suggests the disconnectedness inherent in part-time positions produces its own set of problems. Avakian also asserts that it is challenging for institutions to hire instructors with terminal degrees, especially for a modest salary ranging from $\$ 900$ to $\$ 2500$ per course offered to most adjunct faculty members. Likewise, part-time faculty members are typically hired with little or no input from departmental faculty, which generates concern over program deterioration and lack of involvement in the establishment of academic standards (Centra, 1983; Mayhew, Ford, \& Hubbard, 1990; Rhoades, 1996).

Many part-time faculty members have hope that teaching part-time will lead to full-time work through experience or contact at the institution(s) where they are employed. This very hope is what drives many part-time faculty members to continue in their quest, even if it means continuing to work for less than adequate pay, benefits, shared governance, etc. However, Tuckman and Pickerill (1988) give five reasons why part-time work rarely leads to full-time work: (a) there is no career ladder, (b) over $85 \%$ of part-time positions do not carry tenure, (c) there is no normal salary progression, (d) opportunities for promotion are limited or non-existent, (e) part-time faculty are not full fledged members of their employing departments (p. 109).

\section{Other Issues}

Collective bargaining. Leslie, Kellams, \& Gunne (1982) found that $41 \%$ of public institutions and $28 \%$ of private institutions with collective bargaining have grievance procedures for part-time faculty. Conley et al., in their 2002 research found that only $12 \%$ of part-time 
faculty members were union members. Additionally, part-time faculty members are limited in their ability to negotiate salaries and other needs with institutions (Banachowski, 1996a, 1996b; Gappa \& Leslie, 1993; Lankard, 1993). Organization of part-time faculty at postsecondary institutions is on the rise, and there have been some successful efforts in creating a union for part-time instructors (Baron-Nixon, 2007; Thompson, 1995).

With strong efforts in Boston, Washington, and Chicago, there is currently a nationwide move to organize part-time faculty. The Coalition of Contingent Academic Labor (COCAL) held its fourth annual conference in January 2001. This organization's purpose is to organize parttime faculty to improve teaching conditions, including salaries, benefits, and other working conditions (Delaney, 2001). This effort to organize has been further galvanized by the recent report by the Coalition on the Academic Workforce (CAW) concerning the large numbers of part-timers in postsecondary institutions, especially in areas such as history, English, and the humanities (Townsend, 2000). With the quantitative data to support their cause, many adjuncts are moving to organize into unions to improve their working conditions.

Job security. Lack of job security and employment incentives is a major concern when addressing issues facing part-time faculty (AAUP, 1998; Balch, 1999; Mize, 1998; Styne, 1997). Gappa (2000) stated that 45\% of part-time faculty members in the 1993 NSOPF were not satisfied with job security. In the 1998 NSOPF, 38\% were dissatisfied with job security (Berger et al., 2002). German (1996) stated that $91 \%$ of part-time faculty members were unranked (outside the channels for advancement). Furthermore, 19\% of part-time faculty members were moonlighters or semi-retired professionals (Finucane \& Algren, 1997). Gappa suggests that if faculty members have long relationships with an institution, it is usually because of the goodwill of the institution and not the rights of the part-time faculty. 
In addition, many part-timers face a lack of job security with term-to-term appointments (Balch, 1999; Baron-Nixon, 2007; Curzon-Brown, 1988; Gappa, 2000; Gappa \& Leslie, 1993; Mize, 1998; Wyles, 1998). There is a lack of adequate notice of employment and non-renewal with many adjuncts receiving their assignment the day before the class is to start or losing their classes to full-time faculty at the last minute (AAUP, 1998; Kelly, 1991; Styne, 1997).

\section{Other Related Research}

Other studies reviewed dealt with particular types of faculty or areas of interest. Gappa and Leslie (1993) dealt directly with part-time faculty with a focus on various types of institutions, interviewing administration, full-time, and part-time personnel. They interviewed individually and in groups, chief academic officers, deans, department chairs, tenured faculty members involved in governance and development, and adjunct faculty (a total of 467) at 18 colleges and universities to ascertain the status (emphasis added) of part-time faculty and to better understand the problems faced by such a large number of individuals who teach in our institutions. The institutions were a representation of all types within higher education with some chosen because of specific policies and practices on part-time faculty. Information gathered included part-timers' educational and employment backgrounds and their perceptions of their jobs and information on institutional policies and practices on adjuncts, as well as administrators' and senior faculties' views on the benefits and weaknesses of using adjuncts.

Along with the interview data, written policies, procedures, handbooks, and other materials collected were analyzed by Gappa and Leslie (1993). Although the actual methodology used is discussed only briefly in their book, the researchers were able to provide for trustworthiness and authenticity in their study by establishing transferability and credibility from several perspectives. First, they used 18 institutions in their study that provided for greater 
generalization. Secondly, the use of two researchers and the collection of data from both parttime faculty and administrators improved triangulation. Also strengthening their study was the use of various sources for their document analysis, including policies and practices from the institutional and state level, legislation, court documentation, and other materials (Gappa \& Leslie, 1993).

Their research resulted in a book, The Invisible Faculty: Improving the Status of Parttimers in Higher Education. The book provided an investigation of part-time faculty in higher education. It carefully examined the myths and realities surrounding part-time faculty. Findings of the study, dispersed throughout the literature review, include the following: who serves as part-time faculty including demographic and employment profiles, what forces lead to the use of part-time faculty, how usage is affected by fiscal issues, when and why institutions employ adjuncts, and what institutional policies and practices are in place.

Gappa and Leslie concluded "a college or university strengthens itself through the wise use of part-time faculty" (p. 277). Therefore, they encouraged institutions to take a proactive approach to dealing with part-time faculty. Unfortunately, the status quo is often difficult to overcome within institutions and policy-making arenas. In addition, they warned against the exploitation of adjuncts believing that institutions can do serious long-term damage to the academic integrity by overlooking, overusing, and abusing part-timers. They also concluded that issues of part-time faculty will have to be addressed in order to ensure the quality of the curriculum.

Adjunct faculty members provide a large pool of potential full-time faculty from which institutions may draw. With part-timers carrying a large amount of the teaching load, especially in the lower-level, often foundational classes, it is vital that instructors be of high quality. This is 
extremely important to ensure enough quality teachers for the large number of students who enter the postsecondary system.

Gappa and Leslie (1993) believed that much is to be gained by understanding part-time faculty and integrating them into the academic institution at all levels of participation. These faculty members are skilled teachers that can and do strengthen the academic programs and the overall institution.

Roueche et al. (1995) built on Gappa and Leslie's 1993 study creating a profile of community college part-time faculty from the administrators' perspectives. The two-part study, consisting of a national survey combined with telephone interviews resulted in the book, Strangers in Their Own Land: Part-time Faculty in American Community Colleges. The study had three goals: to review important issues in the part-time faculty debate, to describe the current extent of community colleges' reliance on part-time faculty, and to identify and showcase selected successful part-time faculty utilization and integration programs (p. 23). The researchers surveyed a stratified random sample of member colleges of the American Association of Community Colleges (AACC) with an overall response rate of $62.4 \%$, which is higher than a typical national mail survey. Roueche et al.'s (1995) study dealt directly with community colleges and has both a quantitative and qualitative component.

With the inevitable limitations, Roueche et al. (1995) contend that the data effectively represented "trends in the employment of part-time faculty in AACC member colleges" (p. 27).

From the study, the following data were reported, and conclusions were made:

$>58.3 \%$ of all faculty members in AACC institutions are part-time faculty with district and larger community colleges more likely to employ part-time faculty than smaller institutions. 
Of the credit hours taught, part-time faculty taught $33.6 \%$ while full-time faculty taught $66.3 \%$; no distinction was made for noncredit hours.

The salary range was $\$ 424$ per course to $\$ 3,852$ per course with the mean salary at $\$ 1,197$. Furthermore, institutions that paid full-time faculty more tended to pay part-time faculty more.

Part-time faculty benefits were offered by less than 24 institutions. Where benefits were offered, few part-time faculty members met the minimum requirements.

$>$ Part-time students are more likely than full-time students to be taught by part-time faculty because part-time faculty are more likely to teach at times, the level, and the type of courses in which part-time students enroll.

$54 \%$ of the respondents agreed that part-time faculty would increase in the future, and $26 \%$ felt it would remain the same.

The selection and hiring process was ranked as the most important process in the use of part-time faculty. The remaining issues were ranked in the following order of importance: orientation, evaluation, recruitment, staff development, involvement in college life, and retention of part-time faculty (pg. 37).

Summary. Adjunct faculty members provide a significant service to colleges and universities. They should be recognized and valued as professional colleagues working in collaboration with full-time faculty and administrators to achieve the teaching mission of their institution. However, given the low wages and marginal benefits for adjunct faculty, they are subject to pressures and other time commitments. To make ends meet, travel from job to job is often necessary, cutting into the time available to prepare for classes, grade papers, and provide personalized attention to individual students. This problem is exacerbated by their marginal 
existence in their departments - limited office space, computer access, and the ability to confer with collogues regarding fair grades - further undermining their ability to work and communicate with students. Given all this, it seems clear that the exploitation of adjunct faculty means exploitation of students. Higher education institution administrators continually describe the use of adjunct faculty as necessary, allowing the institution to teach more for less, the practice has instead become a way to earn more in tuition revenue while providing less in education.

To ensure continued high quality education, it is vital adjunct faculty understand their role not only in the institution but also their respective department. Therefore, recruiting, hiring and developing adjuncts involve careful selection. Each step of the process - recruitment, screening, hiring, training, course preparation, support and evaluation - must include a commitment to educational quality and adjunct retention. Adjunct faculty must meet the same educational, professional, and scholarly requirements as their full-time peers. Without this emphasis on quality, the institution's accreditation is put at risk. 


\section{Chapter Three:}

\section{Research Methodology}

As Creswell (2003) notes, employing quantitative methodology requires the researcher to examine relationships between and among variables to better answer questions through surveys and experiments. The quantitative approach is a more detailed description of phenomena and the relationships between them, thus providing a generalization of gathered data with tentative synthesized interpretations. A quantitative methodology is used when the researcher must have the ability to exert control over variables in such a way to increase the probability that observed changes can be attributed to the manipulation of specific variables rather than to other influences beyond the control of the researcher. According to Best and Kahn (1998), quantitative research enables the researcher to answer questions or test hypotheses by reaching valid conclusions about relationships between independent and dependent variables.

This study utilizes a quantitative method - descriptive/causal-comparative design approach. This chapter includes the population surveyed, the survey instrument, the method of data collection, how data is analyzed, and limitations of the study.

\section{Restatement of the Purpose of the Study}

The purpose of this study is to describe the status of adjunct faculty in Maryland public and private four year colleges and universities as perceived by department chairs and explore whether there are significant differences between private versus public on each of the five areas of study: (1) extent of information collected on the professional commitments of their adjunct faculty, (2) extent adjunct faculty are evaluated and what evidence is required, (3) extent adjunct faculty become integrated into the department, (4) extent performance expectations are explained 
to adjunct faculty, and (5) extent adjunct faculty are satisfied with employment conditions in the department.

\section{Research Design}

The design is mostly descriptive - a method of research that gathers information about the present, existing condition (Creswell, 2003). The emphasis is on describing rather than on judging or interpreting. The aim of descriptive research is to verify the present situation in order to elucidate. Moreover, this method allows a flexible approach; thus, when important new issues and questions arise during the duration of the study, further investigation may be conducted.

This method is used to describe the nature of a situation as it exists at the time of the study and to explore the relationships between particular phenomena. The aim of descriptive research is to obtain an accurate profile of the people, events or situations. The researcher used a descriptive design to obtain first-hand data from the respondents so as to formulate rational and sound conclusions and recommendations for the study. However, the use of ANOVAs goes beyond descriptive into inferential. Specifically, since whether the organizations are public or private cannot be controlled, the research design is an exploratory comparative study.

\section{Population and Sample}

Originally, the population consisted of 671 department chairs in Maryland Higher Education Institutions but reduced for the following reasons. One hundred thirteen department chairs were excluded as they were part of graduate schools; two institutions chose not to participate, eliminating 60 department chairs. Their reasoning - completing the survey would add additional duties and stress to faculty. No faculty would come forward at the other institution to guide the process from their institution - a requirement set by their Institutional Review Board (IRB). In total, 173 chairs were eliminated, resulting in a possible sample of 498. This included 
department chairs in Maryland public and private institutions offering Baccalaureate degrees. This number, (498) was further reduced by 67 due to undeliverable mailings, therefore a total of 431 surveys were mailed successfully. After three follow-up mailings, 125 surveys were returned, a $29 \%$ response rate. Not all surveys were complete; therefore, some items constitute less than $100 \%$ responses.

The sample in this research consisted of department chairs because their decisions are guided by systemic imperatives: responsibility to offer courses to meet instructional needs and the need to accommodate the budget given to his or her department by the institution. By including all department chairs, one could anticipate a sufficient number for conducting ANOVA.

\section{Institutional Approval}

The researcher applied for and was granted expedited review by the West Virginia University Institutional Review Board for the Protection of Human Subjects (IRB) (see appendix A). After IRB approval, a pilot study of the survey instrument was conducted in an attempt to determine clarity and viability. Three department chairs (Mathematics, Social Work, and Psychology) excluded from the larger study-sample took part in the pilot study at Frostburg State University.

\section{Pilot Study Results}

The researcher was particularly interested in whether or not the instrument would obtain the desired information (i.e., the department chairs perception); and if not, how the instrument could be improved before use. For that reason, the purpose of the pilot study was twofold: (a) to get a preliminary sense of the clarity of the survey questions, and (b) to determine the reliability and overall quality of the instrument. 
Department chairs were e-mailed the survey with the cover letter attached explaining my purpose in contacting them. Feedback from department chairs in the pilot study was helpful and encouraging; as no revisions were suggested. The department chairs noted the cover letter was excellently written and self-explanatory and the survey well done and easy to follow. Other comments were that the survey was well designed, fairly easy to complete and questions were straight forward and easy to understand. Overall, as one noted a "painless process." With no recommendations to the survey instrument, I proceeded.

\section{Data Collection}

A cover letter and seven-page survey were sent to identified Maryland public and private four year college and university department chairs using Survey Monkey®. The cover letter included the purpose and use of the study, provided the option of not answering questions, and a guarantee of anonymity.

The survey instrument (developed by this researcher) contains seven pages. The first page consists of demographical questions about the respondents' position, administrative and teaching experience, enrollment, gender, ethnicity, and institutional type. There are also three open-ended questions on page one. Pages two through seven of the instrument consist of 64 questions. Participants responded to questions on pages two through seven using a 5-point Likert-type scale with descriptors ranging from 5-strongly agree to 1-strongly disagree.

The instrument is designed to measure the role of part-time faculty in higher education as perceived by department chairs. For analysis, the questions were coded 5-strongly agree; 4agree; 3-not sure; 2-disagree; 1-strongly disagree, and 5-extremely difficult; 4-very difficult; 3difficult; 2-somewhat difficult; and 1-not difficult at all. 
A survey design provides a quantitative or numeric description of attitudes or opinions of a population by studying a sample of that population. From sample results, the researcher may generalize or make claims about the population. The survey is the preferred type of data collection for this study due to low economic design and rapid turnaround for collection.

\section{Data Analysis}

The purpose of this study was to describe the status of adjunct/part-time faculty in Maryland private and public four year colleges and universities as perceived by department chairs and to explore whether there are significant differences between public versus private institutions in department chairs' perceptions regarding adjunct faculty professional commitments, adjunct faculty evaluations, adjunct faculty integration into the department, performance expectations of adjunct faculty, and adjunct faculty employment satisfaction.

Therefore, for this particular study, descriptive statistics and ANOVAs were used as appropriate measures. The institution type (public vs. private) was the independent variable and the department chairs perceptions according to adjunct faculty professional commitments, adjunct faculty evaluations, adjunct faculty integration into the department, performance expectations of adjunct faculty, and adjunct faculty employment satisfaction were the dependent variables. Table 3 aligns the study's five research questions with the appropriate investigative technique. Data were analyzed using descriptive and inferential statistics, recording percentages and frequencies. Analysis was performed with SPSS Graduate Pack 17.0 for Windows®. 
Table 3

Variables, Research Questions, and Items on Survey

\begin{tabular}{lll}
\hline Research Questions & Variables & $\begin{array}{l}\text { Item on } \\
\text { Survey }\end{array}$
\end{tabular}

1a. According to department chairs, to what extent is information collected on the professional commitments of their adjunct faculty?

1b. Is there a significant difference between public and private institutions in the perceptions of department chairs as to the extent information is collected on the professional commitments of their adjunct faculty?

2a. According to department chairs, to what extent are adjunct faculty evaluated and what evidence is required?

2b. Is there a significant difference between public and private institutions in the perceptions of department chairs as to the extent adjunct faculty are evaluated and evidence required?

3a. According to department chairs, to what extent do adjunct faculty members become integrated into the department?

$3 b$. Is there a significant difference between public and private institutions in the perceptions of department chairs as to the extent adjunct faculty become integrated into the department?
Dependent Variable Questions 17-28

Independent Variable

Private vs. Public

See questions 17-28

Descriptive

Statistics (percentages $\&$ frequencies)

\section{ANOVA}

Dependent Variable

Questions 29-38

Independent Variable

See questions 29-38

Private vs. Public

$\begin{array}{ll}\text { Dependent Variable } & \text { See } \\ \text { Questions 39-45 } & \text { questions } \\ \text { Independent Variable } & 39-45 \\ \text { Private vs. Public } & \end{array}$

Descriptive

Statistics

(percentages

\& frequencies)

ANOVA

ANOVA 
4a. According to department chairs, to what extent are performance expectations explained to adjunct faculty?
Dependent Variable Questions 46-56 Independent Variable Private vs. Public

$\begin{array}{ll}\text { See } & \begin{array}{l}\text { Descriptive } \\ \text { Statistics }\end{array} \\ \text { questions } & \text { (percentages } \\ 46-56 & \text { \& frequencies) }\end{array}$

ANOVA

4b. Is there a significant difference

\begin{tabular}{|c|c|}
\hline & ANOVA \\
\hline $\begin{array}{l}\text { See } \\
\text { questions } \\
57-67\end{array}$ & $\begin{array}{l}\text { Descriptive } \\
\text { Statistics } \\
\text { (percentages } \\
\text { \& frequencies }\end{array}$ \\
\hline
\end{tabular}

\begin{tabular}{|c|c|c|}
\hline $\begin{array}{l}\text { Dependent Variable } \\
\text { Questions } 57-67 \\
\text { Independent Variable } \\
\text { Private vs. Public }\end{array}$ & $\begin{array}{l}\text { See } \\
\text { questions } \\
57-67\end{array}$ & $\begin{array}{l}\text { Descriptive } \\
\text { Statistics } \\
\text { (percentages } \\
\text { \& frequencies }\end{array}$ \\
\hline
\end{tabular}
ANOVA

$5 b$. Is there a significant difference between public and private institutions in the perceptions of department chairs as to the extent adjunct faculty are satisfied with employment conditions in the department?

\section{Limitations of the Study}

The primary limitation of this study is external validity. This study and population were limited to a single state. Consequently, chair responses may not have been representative of fouryear institutions in other states. The majority of responses was from Liberal Arts and Sciences and may not be representative of other schools/departments.

\section{Summary}

This chapter discussed the methods used to address and test the research questions identified in Chapter One. The research design was identified as descriptive and exploratory causal comparative. The population, instrumentation, data collection, data analysis, and limitations were discussed. 


\section{Chapter Four:}

\section{Findings}

\section{Introduction}

This chapter presents detailed findings and results of the research study. The first section presents the research questions, demographic data of the department chairs in the study followed by the survey questions.

\section{Descriptive Statistics}

The population for this study was $(\mathrm{N}=431)$ department chairs in Maryland public and private higher education institutions. Electronic surveys were mailed successfully and after three follow-up mailings, 125 surveys were returned representing a 29\% response rate. To address each research question, crosstab analysis was conducted which provided basic descriptive information (percentages and frequencies) for each survey item and a measure of association between the independent variable (private and public) and the research area (e.g., extent to which information is collected).

After descriptive statistics had been obtained for each survey item, an individual department chair's scores were summed across all survey items in a given area. For example, for research question one; scores for items 17 through 28 were combined. The resulting composite scores were then averaged separately for chairs from private institutions and chairs from public institutions. These mean scores (public vs. private) were then compared for each research area using an ANOVA.

The research questions were:

1. According to department chairs, to what extent is information collected on the professional commitments of their adjunct faculty? Is there a significant difference between public and private 
institutions in the perceptions of department chairs as to the extent information is collected on the professional commitments of their adjunct faculty?

2. According to department chairs, to what extent are adjunct faculty evaluated and what evidence is required? Is there a significant difference between public and private institutions in the perceptions of department chairs as to the extent adjunct faculty members are evaluated and what evidence is required?

3. According to department chairs, to what extent do adjunct faculty become integrated into the department? Is there a significant difference between public and private institutions in the perceptions of department chairs as to the extent adjunct faculty become integrated into the department?

4. According to department chairs, to what extent are performance expectations explained to adjunct faculty? Is there a significant difference between public and private institutions in the perceptions of department chairs as to the extent performance expectations are explained to adjunct faculty?

5. According to department chairs, to what extent are adjunct faculty satisfied with employment conditions in the department? Is there a significant difference between public and private institutions in the perceptions of department chairs as to the extent adjunct faculty is satisfied with employment conditions in the department?

Specific demographics are as follows. Department chairs completing the survey consisted of $56.8 \%$ males and $39.2 \%$ females (Table 4 ). 
Table 4

Gender of Chairs Completing Survey

\begin{tabular}{|ll|l|l|l|l|}
\hline & & & & & $\begin{array}{l}\text { Cumulative } \\
\text { Percent }\end{array}$ \\
\hline Valid & Male & 71 & 56.8 & 59.2 & 59.2 \\
& Female & 49 & 39.2 & 40.8 & 100.0 \\
& Total & 120 & 96.0 & 100.0 & \\
Missing & System & 5 & 4.0 & & \\
Total & & 125 & 100.0 & & \\
\hline
\end{tabular}

A majority, (52.8\%) had served as chair between 1-5 years, followed by $29.6 \%$ serving 6-

10 years (table 5 ).

Table 5

Years Served as Department Chair

\begin{tabular}{|ll|r|r|r|r|}
\hline & & & & \multicolumn{2}{c|}{$\begin{array}{c}\text { Cumulative } \\
\text { Percent }\end{array}$} \\
\hline Valid & Frequency & Percent & Valid Percent & 54.5 \\
& 6-10 Years & 66 & 52.8 & 54.5 & 54.5 \\
& 37 & 29.6 & 30.6 & 85.1 \\
& 11-15 Years & 9 & 7.2 & 7.4 & 92.6 \\
& 16-20 Years & 6 & 4.8 & 5.0 & 97.5 \\
& 21-25 Years & 1 & .8 & .8 & 98.3 \\
& More than 25 & 2 & 1.6 & 1.7 & 100.0 \\
& Years & 121 & 96.8 & 100.0 & \\
& Total & 4 & 3.2 & & \\
Missing System & 125 & 100.0 & & \\
Total & & & & \\
\hline
\end{tabular}

Somewhat surprisingly, $32.8 \%$ of chairs have taught more than 25 years in college and/or university (Table 6). 
Table 6

Taught in College/University

\begin{tabular}{|ll|r|r|r|r|}
\hline & & & & \multicolumn{2}{c|}{$\begin{array}{c}\text { Cumulative } \\
\text { Percent }\end{array}$} \\
\hline Valid & Frequency & Percent & Valid Percent & 7.4 & 7.4 \\
& 11-15 Years & 9 & 7.2 & 19.8 & 27.3 \\
& 16-20 Years & 19 & 15.2 & 15.7 & 43.0 \\
& 21-25 Years & 28 & 22.4 & 23.1 & 66.1 \\
& More than 25 & 41 & 32.8 & 33.9 & 100.0 \\
& Years & 121 & 96.8 & 100.0 & \\
& Total & 4 & 3.2 & & \\
Missing & System & 125 & 100.0 & & \\
Total & & & & \\
\hline
\end{tabular}

Chairs from both public (52\%) and private (44\%) institutions were well represented (Table 7).

Table 7

\section{Public/Private Institutions}

\begin{tabular}{|ll|r|r|r|r|}
\hline & Frequency & Percent & Valid Percent & $\begin{array}{c}\text { Cumulative } \\
\text { Percent }\end{array}$ \\
\hline Valid & Public & 65 & 52.0 & 54.2 & 54.2 \\
& Private & 55 & 44.0 & 45.8 & 100.0 \\
& Total & 120 & 96.0 & 100.0 & \\
Missing & System & 5 & 4.0 & & \\
Total & & 125 & 100.0 & & \\
\hline
\end{tabular}

Eighty-six percent of chairs completing the survey had earned the doctorate, with $8.8 \%$ holding a masters degree (Table 8). 
Table 8

Highest Degree Earned of Participants

\begin{tabular}{|ll|r|r|r|r|}
\hline & & Frequency & Percent & Valid Percent & Cumulative Percent \\
\hline Valid & Doctorate & 108 & 86.4 & 90.8 & 90.8 \\
& Masters & 11 & 8.8 & 9.2 & 100.0 \\
& Total & 119 & 95.2 & 100.0 & \\
Missing & System & 6 & 4.8 & & \\
Total & & 125 & 100.0 & & \\
\hline
\end{tabular}

Ethnicity of adjuncts hired were White (40\%), Black (19\%), Hispanic (14\%), Asian (16\%), and other (11.3\%) (Table 9).

Table 9

Adjuncts Hired by Ethnicity

\begin{tabular}{|ll|r|r|r|r|}
\hline & & Frequency & Percent & Valid Percent & Cumulative Percent \\
\hline Valid & White & 107 & 40.4 & 40.4 & 40.4 \\
& Black & 50 & 18.9 & 18.9 & 59.3 \\
& Hispanic & 36 & 13.6 & 13.6 & 72.9 \\
& Asian & 42 & 15.8 & 15.8 & 88.7 \\
& Other & 30 & 11.3 & 11.3 & 100.0 \\
& Total & 265 & 100.0 & 100.0 & \\
& & & & & \\
Missing & System & 0 & 0 & & \\
Total & & 265 & 100.0 & & \\
\hline
\end{tabular}

Most department chairs (87.2\%) were responsible for the hiring of adjunct faculty (Table 10). 
Table 10

Who Hires Adjunct Faculty

\begin{tabular}{|ll|r|r|r|r|}
\hline & & & & \multicolumn{2}{c|}{$\begin{array}{c}\text { Cumulative } \\
\text { Percent }\end{array}$} \\
\hline Valid $\quad$ Chair & Frequency & Percent & Valid Percent & 90.1 & 90.1 \\
& Dept tenured faculty & 109 & 87.2 & 5.8 & 95.9 \\
& Dean & 7 & 5.6 & 4.1 & 100.0 \\
& Total & 5 & 4.0 & 100.0 & \\
Missing & System & 121 & 96.8 & & \\
Total & & 4 & 3.2 & & \\
\hline
\end{tabular}

The reasons for hiring adjunct faculty were reviewed and grouped into the following categories: expertise, sabbatical, increased enrollment, budget restraints, insufficient full-time faculty, teaches Introduction courses, and other (Table 11). The highest percent $(30.4 \%)$ of respondents reported the reasons for hiring adjunct faculty was insufficient full-time faculty followed by (19.2\%) due to increased enrollment. 
Table 11

Main Reasons for Hiring Adjunct Faculty

\begin{tabular}{|ll|r|r|r|r|}
\hline & & & & Cumulative \\
& & Frequency & Percent & Valid Percent & \multicolumn{2}{|c|}{ Percent } \\
\hline Valid $\quad$ Expertise & 22 & 17.6 & 19.1 & 19.1 \\
& Sabbatical & 5 & 4.0 & 4.3 & 23.5 \\
& Increased enrollment & 24 & 19.2 & 20.9 & 44.3 \\
& Budget restraints & 8 & 6.4 & 7.0 & 51.3 \\
& Insufficient f-t faculty & 38 & 30.4 & 33.0 & 84.3 \\
& Teach intro courses & 11 & 8.8 & 9.6 & 93.9 \\
& Other & 7 & 5.6 & 6.1 & 100.0 \\
& Total & 115 & 92.0 & 100.0 & \\
Missing System & 10 & 8.0 & & \\
Total & & 125 & 100.0 & & \\
\hline
\end{tabular}

The maximum number of credit hours adjuncts are allowed to teach a semester according to department chairs was 4-6 (30.4\%) followed by 7-9 (24.8\%) (Table 12).

Table 12

Maximum Number Credit hours Adjuncts can Teach

\begin{tabular}{|ll|r|r|r|r|}
\hline & & & & \multicolumn{2}{c|}{$\begin{array}{c}\text { Cumulative } \\
\text { Percent }\end{array}$} \\
\hline Valid & Frequency & Percent & Valid Percent & 13.2 & 13.2 \\
& $4-6$ & 15 & 12.0 & 33.3 & 46.5 \\
& $7-9$ & 38.4 & 27.2 & 73.7 \\
& More than 9 & 31 & 24.8 & 26.3 & 100.0 \\
& Total & 114 & 91.2 & 100.0 & \\
Missing & System & 11 & 8.8 & & \\
Total & & 125 & 100.0 & & \\
\hline
\end{tabular}


Department chairs were asked how difficult it is to identify and employ qualified adjunct faculty to meet their programs needs. They responded as follows: Extremely difficult, Very difficult, Difficult, Somewhat difficult, and Not difficult at all. Thirty-nine department chairs found it somewhat difficult (31.2\%) followed by 27 (21.6\%) found it difficult. Eleven department chairs found it extremely difficult $(8.8 \%)$ to identify and employ qualified adjunct faculty (Table 13).

Table 13

Difficult to Hire Adjunct Faculty

\begin{tabular}{|rl|r|r|r|r|}
\hline & & & & & Cumulative \\
& & Frequency & Percent & Valid Percent & Percent \\
\hline & Not difficult at all & 25 & 20.0 & 21.4 & 21.4 \\
& Somewhat difficult & 39 & 31.2 & 33.3 & 54.7 \\
& Difficult & 27 & 21.6 & 23.1 & 77.8 \\
& Very difficult & 15 & 12.0 & 12.8 & 90.6 \\
& Extremely difficult & 11 & 8.8 & 9.4 & 100.0 \\
& Total & 117 & 93.6 & 100.0 & \\
Missing & System & 8 & 6.4 & & \\
Total & & 125 & 100.0 & & \\
\hline
\end{tabular}

Department names were reviewed and placed into five categories as follows: Business (10\%), Education (3.6\%), Liberal Arts (47.3\%), Sciences (27.3\%), and Other (11.8\%) (Table 14). 
Table 14

Department Categories

\begin{tabular}{|ll|r|r|r|r|}
\hline & & & & \multicolumn{2}{c|}{$\begin{array}{c}\text { Cumulative } \\
\text { Percent }\end{array}$} \\
\hline Valid & Business & 11 & 8.8 & 10.0 & 10.0 \\
& Education & 4 & 3.2 & 3.6 & 13.6 \\
& Liberal arts & 52 & 41.6 & 47.3 & 60.9 \\
& Sciences & 30 & 24.0 & 27.3 & 88.2 \\
& Other & 13 & 10.4 & 11.8 & 100.0 \\
& Total & 110 & 88.0 & 100.0 & \\
Missing & System & 15 & 12.0 & & \\
Total & & 125 & 100.0 & & \\
\hline
\end{tabular}

\section{Research Question One}

The first research question asked: According to department chairs, to what extent is information collected on the professional commitments of their adjunct faculty? This research question was answered by analyzing responses to survey questions 17 through 28 conducting a crosstab analysis. Table 15 shows the answers to survey question 17 by providing descriptive statistics, frequencies, and percentages.

A moderate association (Cramer's $V=.219$ ) (Table 16) was found between the type of school (public/private) and survey question 17: Adjunct faculty commitments at other institutions is a concern for me. While there was a moderate association between the type of school and concerns about whether the adjunct faculty had commitments at other institutions, this association was not significant. 
Table 15

Crosstab

\begin{tabular}{|c|c|c|c|c|c|}
\hline \multirow[t]{2}{*}{ Q. 17} & \multirow{2}{*}{\multicolumn{2}{|c|}{$\begin{array}{l}\text { Adjunct faculty } \\
\text { commitments at other } \\
\text { institutions is a concern for } \\
\text { me }\end{array}$}} & \multicolumn{3}{|c|}{ C9 $=$ Public/Private Institutions } \\
\hline & & & Public & Private & Total \\
\hline & \multirow[t]{2}{*}{ Strongly disagree } & Count & 5 & 10 & 15 \\
\hline & & $\%$ within C9 & $8.5 \%$ & $20.4 \%$ & $13.9 \%$ \\
\hline & \multirow[t]{2}{*}{ Disagree } & Count & 30 & 16 & 46 \\
\hline & & $\%$ within C9 & $50.8 \%$ & $32.7 \%$ & $42.6 \%$ \\
\hline & \multirow[t]{2}{*}{ Not sure } & Count & 4 & 4 & 8 \\
\hline & & $\%$ within C9 & $6.8 \%$ & $8.2 \%$ & $7.4 \%$ \\
\hline & \multirow[t]{2}{*}{ Agree } & Count & 15 & 15 & 30 \\
\hline & & $\%$ within C9 & $25.4 \%$ & $30.6 \%$ & $27.8 \%$ \\
\hline & \multirow[t]{2}{*}{ Strongly agree } & Count & 5 & 4 & 9 \\
\hline & & $\%$ within C9 & $8.5 \%$ & $8.2 \%$ & $8.3 \%$ \\
\hline & \multirow[t]{2}{*}{ Total } & Count & 59 & 49 & 108 \\
\hline & & $\%$ within C9 & $100.0 \%$ & $100.0 \%$ & $100.0 \%$ \\
\hline
\end{tabular}

Table 16

Symmetric Measures

\begin{tabular}{|ll|r|r|}
\hline & & \multicolumn{1}{|c|}{ Value } & Approx. Sig. \\
\hline Nominal by Nominal & Phi & .219 & .272 \\
& Cramer's V & .219 & .272 \\
& N of Valid Cases & 108 & \\
& & & \\
\hline
\end{tabular}

Table 17 shows the answers to survey question 18 by providing descriptive statistics, frequencies, and percentages. No association (Cramer's $V=.080)($ Table 18$)$ was found between 
the type of school (public/private) and survey question 18: Adjunct faculty teaching at other colleges and universities should not exceed four courses.

Table 17

Crosstab

\begin{tabular}{|c|c|c|c|c|c|}
\hline \multirow[t]{2}{*}{ Q. 18} & \multirow{2}{*}{\multicolumn{2}{|c|}{$\begin{array}{l}\text { Adjunct faculty teaching at } \\
\text { other colleges and } \\
\text { universities should not } \\
\text { exceed four courses }\end{array}$}} & \multicolumn{3}{|c|}{ C9 = Public/Private Institutions } \\
\hline & & & Public & Private & Total \\
\hline & \multirow[t]{2}{*}{ Strongly disagree } & Count & 2 & 2 & 4 \\
\hline & & $\%$ within C9 & $3.4 \%$ & $4.1 \%$ & $3.7 \%$ \\
\hline & \multirow[t]{2}{*}{ Disagree } & Count & 7 & 8 & 15 \\
\hline & & $\%$ within C9 & $11.9 \%$ & $16.3 \%$ & $13.9 \%$ \\
\hline & \multirow[t]{2}{*}{ Not sure } & Count & 16 & 14 & 30 \\
\hline & & $\%$ within C9 & $27.1 \%$ & $28.6 \%$ & $27.8 \%$ \\
\hline & \multirow[t]{2}{*}{ Agree } & Count & 20 & 14 & 34 \\
\hline & & $\%$ within C9 & $33.9 \%$ & $28.6 \%$ & $31.5 \%$ \\
\hline & \multirow[t]{2}{*}{ Strongly agree } & Count & 14 & 11 & 25 \\
\hline & & $\%$ within C9 & $23.7 \%$ & $22.4 \%$ & $23.1 \%$ \\
\hline & \multirow[t]{2}{*}{ Total } & Count & 59 & 49 & 108 \\
\hline & & $\%$ within C9 & $100.0 \%$ & $100.0 \%$ & $100.0 \%$ \\
\hline
\end{tabular}

Table 18

Symmetric Measures

\begin{tabular}{|ll|r|r|}
\hline & & \multicolumn{1}{|c|}{ Value } & Approx. Sig. \\
\hline Nominal by Nominal & Phi & .080 & .951 \\
& Cramer's V & .080 & .951 \\
& N of Valid Cases & 108 & \\
\hline
\end{tabular}


Table 19 shows the answers to survey question 19 by providing descriptive statistics, frequencies, and percentages. A small association (Cramer's $V=.122)($ Table 20) was found between the type of school (public/private) and survey question 19: Adjunct faculty are required to share information with department chairs regarding other professional commitments. This small association was not significant.

Table 19

\section{Crosstab}

\begin{tabular}{|c|c|c|c|c|c|}
\hline \multirow[t]{2}{*}{ Q. 19} & \multirow{2}{*}{\multicolumn{2}{|c|}{$\begin{array}{l}\text { Adjunct faculty are } \\
\text { required to share } \\
\text { information with } \\
\text { department chairs } \\
\text { regarding other } \\
\text { professional commitments }\end{array}$}} & \multicolumn{3}{|c|}{ C9 = Public/Private Institutions } \\
\hline & & & Public & Private & Total \\
\hline & \multirow[t]{2}{*}{ Strongly disagree } & Count & 3 & 5 & \\
\hline & & $\%$ within C9 & $5.1 \%$ & $10.2 \%$ & $7.4 \%$ \\
\hline & \multirow[t]{2}{*}{ Disagree } & Count & 19 & 15 & 34 \\
\hline & & $\%$ within $\mathrm{C} 9$ & $32.2 \%$ & $30.6 \%$ & $31.5 \%$ \\
\hline & \multirow[t]{2}{*}{ Not sure } & Count & 9 & 5 & 14 \\
\hline & & $\%$ within $\mathrm{C} 9$ & $15.3 \%$ & $10.2 \%$ & $13.0 \%$ \\
\hline & \multirow[t]{2}{*}{ Agree } & Count & 22 & 18 & 40 \\
\hline & & $\%$ within C9 & $37.3 \%$ & $36.7 \%$ & $37.0 \%$ \\
\hline & \multirow[t]{2}{*}{ Strongly agree } & Count & 6 & 6 & 12 \\
\hline & & $\%$ within $\mathrm{C} 9$ & $10.2 \%$ & $12.2 \%$ & $11.1 \%$ \\
\hline & \multirow[t]{2}{*}{ Total } & Count & 59 & 49 & 108 \\
\hline & & $\%$ within C9 & $100.0 \%$ & $100.0 \%$ & $100.0 \%$ \\
\hline
\end{tabular}


Table 20

Symmetric Measures

\begin{tabular}{|ll|r|r|}
\hline & & \multicolumn{1}{|c|}{ Value } & Approx. Sig. \\
\hline Nominal by Nominal & Phi & .122 & .809 \\
& Cramer's V & .122 & .809 \\
& N of Valid Cases & 108 & \\
\hline
\end{tabular}

Table 21 shows the answers to survey question 20 by providing descriptive statistics, frequencies, and percentages. A moderate association (Cramer's V $=.211$ ) (Table 22) was found between the type of school (public/private) and survey question 20: There is a limit on the number of courses adjunct teach elsewhere. While there was a moderate association between the type of school and limit on the number of courses adjunct teach elsewhere, this association was not significant. 
Table 21

\section{Crosstab}

\begin{tabular}{|c|c|c|c|c|c|}
\hline \multirow[t]{2}{*}{ Q. 20} & \multicolumn{2}{|c|}{$\begin{array}{l}\text { There is a limit on the } \\
\text { number of courses adjunct } \\
\text { teach elsewhere }\end{array}$} & \multicolumn{3}{|c|}{ C9 = Public/Private Institutions } \\
\hline & & & Public & Private & Total \\
\hline & \multirow[t]{2}{*}{ Strongly disagree } & Count & 3 & 8 & 11 \\
\hline & & $\%$ within C9 & $5.1 \%$ & $16.3 \%$ & $10.2 \%$ \\
\hline & \multirow[t]{2}{*}{ Disagree } & Count & 24 & 15 & 39 \\
\hline & & $\%$ within $\mathrm{C} 9$ & $40.7 \%$ & $30.6 \%$ & $36.1 \%$ \\
\hline & \multirow[t]{2}{*}{ Not sure } & Count & 15 & 15 & 30 \\
\hline & & $\%$ within C9 & $25.4 \%$ & $30.6 \%$ & $27.8 \%$ \\
\hline & \multirow[t]{2}{*}{ Agree } & Count & 13 & 8 & 21 \\
\hline & & $\%$ within C9 & $22.0 \%$ & $16.3 \%$ & $19.4 \%$ \\
\hline & \multirow[t]{2}{*}{ Strongly agree } & Count & 4 & 3 & 7 \\
\hline & & $\%$ within C9 & $6.8 \%$ & $6.1 \%$ & $6.5 \%$ \\
\hline & \multirow[t]{2}{*}{ Total } & Count & 59 & 49 & 108 \\
\hline & & $\%$ within C9 & $100.0 \%$ & $100.0 \%$ & $100.0 \%$ \\
\hline
\end{tabular}

Table 22

Symmetric Measures

\begin{tabular}{|ll|r|r|}
\hline & & \multicolumn{1}{|c|}{ Value } & Approx. Sig. \\
\hline Nominal by Nominal & Phi & .211 & .309 \\
& Cramer's V & .211 & .309 \\
& N of Valid Cases & 108 & \\
\hline
\end{tabular}

Table 23 shows the answers to survey question 21 by providing descriptive statistics, frequencies, and percentages. A small association (Cramer's $V=.154$ ) (Table 24) was found between the type of school (public/private) and survey question 21: Adjunct faculty are required 
to inform department chairs of other professional workload obligations. This small association was not significant.

Table 23

Crosstab

\begin{tabular}{|c|c|c|c|c|c|}
\hline \multirow[t]{2}{*}{ Q. 21} & \multirow{2}{*}{\multicolumn{2}{|c|}{$\begin{array}{l}\text { Adjunct faculty are } \\
\text { required to inform } \\
\text { department chairs of other } \\
\text { professional workload } \\
\text { obligations }\end{array}$}} & \multicolumn{3}{|c|}{ C9 = Public/Private Institutions } \\
\hline & & & Public & Private & Total \\
\hline & \multirow[t]{2}{*}{ Strongly disagree } & Count & 4 & 7 & 11 \\
\hline & & $\%$ within C9 & $6.8 \%$ & $14.6 \%$ & $10.3 \%$ \\
\hline & \multirow[t]{2}{*}{ Disagree } & Count & 21 & 14 & 35 \\
\hline & & $\%$ within C9 & $35.6 \%$ & $29.2 \%$ & $32.7 \%$ \\
\hline & \multirow[t]{2}{*}{ Not sure } & Count & 7 & 7 & 14 \\
\hline & & $\%$ within C9 & $11.9 \%$ & $14.6 \%$ & $13.1 \%$ \\
\hline & \multirow[t]{2}{*}{ Agree } & Count & 21 & 17 & 38 \\
\hline & & $\%$ within C9 & $35.6 \%$ & $35.4 \%$ & $35.5 \%$ \\
\hline & \multirow[t]{2}{*}{ Strongly agree } & Count & 6 & 3 & 9 \\
\hline & & $\%$ within $\mathrm{C} 9$ & $10.2 \%$ & $6.3 \%$ & $8.4 \%$ \\
\hline & \multirow[t]{2}{*}{ Total } & Count & 59 & 48 & 107 \\
\hline & & $\%$ within $\mathrm{C} 9$ & $100.0 \%$ & $100.0 \%$ & $100.0 \%$ \\
\hline
\end{tabular}

Table 24

Symmetric Measures

\begin{tabular}{|ll|r|r|}
\hline & & Value & Approx. Sig. \\
\hline Nominal by Nominal & Phi & .154 & .638 \\
& Cramer's V & .154 & .638 \\
& N of Valid Cases & 107 & \\
\hline
\end{tabular}


Table 25 shows the answers to survey question 22 by providing descriptive statistics, frequencies, and percentages. A small association (Cramer's $V=.159$ ) (Table 26) was found between the type of school (public/private) and survey question 22: Having several outside professional commitments raises concern in their employability. This small association was not significant.

Table 25

\section{Crosstab}

\begin{tabular}{|c|c|c|c|c|}
\hline \multicolumn{2}{|c|}{$\begin{array}{l}\text { Q. } 22 \text { Having several outside } \\
\text { professional commitments } \\
\text { raises concern in their } \\
\text { employability }\end{array}$} & \multicolumn{3}{|c|}{$\mathrm{C} 9=$ Public/Private Institutions } \\
\hline & & Public & Private & Total \\
\hline \multirow[t]{2}{*}{ Strongly disagree } & Count & 1 & 4 & 3 \\
\hline & $\%$ within $\mathrm{C} 9$ & $1.7 \%$ & $8.3 \%$ & $4.7 \%$ \\
\hline \multirow[t]{2}{*}{ Disagree } & Count & 19 & 14 & 33 \\
\hline & $\%$ within C9 & $32.2 \%$ & $29.2 \%$ & $30.8 \%$ \\
\hline \multirow[t]{2}{*}{ Not sure } & Count & 11 & 9 & 20 \\
\hline & $\%$ within C9 & $18.6 \%$ & $18.8 \%$ & $18.7 \%$ \\
\hline \multirow[t]{2}{*}{ Agree } & Count & 22 & 17 & 39 \\
\hline & $\%$ within $\mathrm{C} 9$ & $37.3 \%$ & $35.4 \%$ & $36.4 \%$ \\
\hline \multirow[t]{2}{*}{ Strongly agree } & Count & 6 & 4 & 10 \\
\hline & $\%$ within C9 & $10.2 \%$ & $8.3 \%$ & $9.3 \%$ \\
\hline \multirow[t]{2}{*}{ Total } & Count & 59 & 48 & 107 \\
\hline & $\%$ within C9 & $100.0 \%$ & $100.0 \%$ & $100.0 \%$ \\
\hline
\end{tabular}


Table 26

Symmetric Measures

\begin{tabular}{|ll|r|r|}
\hline & & \multicolumn{1}{|c|}{ Value } & Approx. Sig. \\
\hline Nominal by Nominal & Phi & .159 & .610 \\
& Cramer's V & .159 & .610 \\
& N of Valid Cases & 107 & \\
\hline
\end{tabular}

Table 27 shows the answers to survey question 23 by providing descriptive statistics, frequencies, and percentages. No association (Cramer's $V=.092)($ Table 28$)$ was found between the type of school (public/private) and question 23: There should be limitations on outside professional commitments for adjunct faculty.

Table 27

Crosstab

\begin{tabular}{|c|c|c|c|c|c|}
\hline \multirow[t]{2}{*}{ Q. 23} & \multicolumn{2}{|c|}{$\begin{array}{l}\text { There should be limitations on } \\
\text { outside professional } \\
\text { commitments for adjunct } \\
\text { faculty }\end{array}$} & \multicolumn{3}{|c|}{$\mathrm{C} 9=$ Public/Private Institutions } \\
\hline & & & Public & Private & Total \\
\hline & \multirow[t]{2}{*}{ Strongly disagree } & Count & 9 & 8 & 17 \\
\hline & & $\%$ within C9 & $15.3 \%$ & $16.7 \%$ & $15.9 \%$ \\
\hline & \multirow[t]{2}{*}{ Disagree } & Count & 21 & 17 & 38 \\
\hline & & $\%$ within C9 & $35.6 \%$ & $35.4 \%$ & $35.5 \%$ \\
\hline & \multirow[t]{2}{*}{ Not sure } & Count & 10 & 9 & 19 \\
\hline & & $\%$ within C9 & $16.9 \%$ & $18.8 \%$ & $17.8 \%$ \\
\hline & \multirow[t]{2}{*}{ Agree } & Count & 17 & 11 & 28 \\
\hline & & $\%$ within C9 & $28.8 \%$ & $22.9 \%$ & $26.2 \%$ \\
\hline & \multirow[t]{2}{*}{ Strongly agree } & Count & 2 & 3 & 5 \\
\hline & & $\%$ within $\mathrm{C} 9$ & $3.4 \%$ & $6.3 \%$ & $4.7 \%$ \\
\hline & \multirow[t]{2}{*}{ Total } & Count & 59 & 48 & 107 \\
\hline & & $\%$ within $\mathrm{C} 9$ & $100.0 \%$ & $100.0 \%$ & $100.0 \%$ \\
\hline
\end{tabular}


Table 28

Symmetric Measures

\begin{tabular}{|ll|r|r|}
\hline & & \multicolumn{1}{|c|}{ Value } & Approx. Sig. \\
\hline Nominal by Nominal & Phi & .092 & .925 \\
& Cramer's V & .092 & .925 \\
& N of Valid Cases & 107 & \\
\hline
\end{tabular}

Table 29 shows the answers to survey question 24 by providing descriptive statistics, frequencies, and percentages. A small association (Cramer's V = .162) (Table 30) was found between the type of school (public/private) and survey question 24: My institution has a set hiring policy or contract for adjunct faculty. This small association was not significant.

Table 29

\section{Crosstab}

\begin{tabular}{|c|c|c|c|c|c|}
\hline \multirow[t]{2}{*}{ Q. 24} & \multicolumn{2}{|c|}{$\begin{array}{l}\text { My institution has a set hiring } \\
\text { policy or contract for adjunct } \\
\text { faculty }\end{array}$} & \multicolumn{3}{|c|}{$\mathrm{C} 9=$ Public/Private Institutions } \\
\hline & & & Public & Private & Total \\
\hline & \multirow[t]{2}{*}{ Strongly disagree } & Count & 3 & 3 & 6 \\
\hline & & $\%$ within C9 & $5.0 \%$ & $6.3 \%$ & $5.6 \%$ \\
\hline & \multirow[t]{2}{*}{ Disagree } & Count & 8 & 11 & 19 \\
\hline & & $\%$ within C9 & $13.3 \%$ & $22.9 \%$ & $17.6 \%$ \\
\hline & \multirow[t]{2}{*}{ Not sure } & Count & 5 & 6 & 11 \\
\hline & & $\%$ within C9 & $8.3 \%$ & $12.5 \%$ & $10.2 \%$ \\
\hline & \multirow[t]{2}{*}{ Agree } & Count & 30 & 19 & 49 \\
\hline & & $\%$ within C9 & $50.0 \%$ & $39.6 \%$ & $45.4 \%$ \\
\hline & \multirow[t]{2}{*}{ Strongly agree } & Count & 14 & 9 & 23 \\
\hline & & $\%$ within C9 & $23.3 \%$ & $18.8 \%$ & $21.3 \%$ \\
\hline & \multirow[t]{2}{*}{ Total } & Count & 60 & 48 & 108 \\
\hline & & \% within C9 & $100.0 \%$ & $100.0 \%$ & $100.0 \%$ \\
\hline
\end{tabular}


Table 30

Symmetric Measures

\begin{tabular}{|ll|r|r|}
\hline & & \multicolumn{1}{|c|}{ Value } & Approx. Sig. \\
\hline Nominal by Nominal & Phi & .162 & .588 \\
& Cramer's V & .162 & .588 \\
& N of Valid Cases & 108 & \\
\hline
\end{tabular}

Table 31 shows the answers to survey question 25 by providing descriptive statistics, frequencies, and percentages. A moderate association (Cramer's $V=.225$ ) (Table 32) was found between the type of school (public/private) and survey question 25: Locally recruited adjunct faculty are less competent than those hired through national searches. While there was a moderate association between the type of school and whether locally recruited adjunct faculty members are less competent than those hired through national searches, this association was not significant. 
Table 31

\section{Crosstab}

\begin{tabular}{|c|c|c|c|c|c|}
\hline \multirow[t]{2}{*}{ Q. 25} & \multicolumn{2}{|c|}{$\begin{array}{l}\text { Locally recruited adjunct } \\
\text { faculty are less competent } \\
\text { than those hired through } \\
\text { national searches }\end{array}$} & \multicolumn{3}{|c|}{$\mathrm{C} 9=$ Public/Private Institutions } \\
\hline & & & Public & Private & Total \\
\hline & \multirow[t]{2}{*}{ Strongly disagree } & Count & 19 & 16 & 35 \\
\hline & & $\%$ within C9 & $32.2 \%$ & $33.3 \%$ & $32.7 \%$ \\
\hline & \multirow[t]{2}{*}{ Disagree } & Count & 29 & 18 & 47 \\
\hline & & $\%$ within C9 & $49.2 \%$ & $37.5 \%$ & $43.9 \%$ \\
\hline & \multirow[t]{2}{*}{ Not sure } & Count & 6 & 12 & 18 \\
\hline & & $\%$ within C9 & $10.2 \%$ & $25.0 \%$ & $16.8 \%$ \\
\hline & \multirow[t]{2}{*}{ Agree } & Count & 4 & 2 & 6 \\
\hline & & $\%$ within C9 & $6.8 \%$ & $4.2 \%$ & $5.6 \%$ \\
\hline & \multirow[t]{2}{*}{ Strongly agree } & Count & 1 & 0 & 1 \\
\hline & & $\%$ within C9 & $1.7 \%$ & $.0 \%$ & $.9 \%$ \\
\hline & \multirow[t]{2}{*}{ Total } & Count & 59 & 48 & 107 \\
\hline & & $\%$ within C9 & $100.0 \%$ & $100.0 \%$ & $100.0 \%$ \\
\hline
\end{tabular}

Table 32

Symmetric Measures

\begin{tabular}{|ll|r|r|}
\hline & & \multicolumn{1}{|c|}{ Value } & Approx. Sig. \\
\hline Nominal by Nominal & Phi & .225 & .246 \\
& Cramer's V & .225 & .246 \\
& N of Valid Cases & 107 & \\
\hline
\end{tabular}

Table 33 shows the answers to survey question 26 by providing descriptive statistics, frequencies, and percentages. A small association (Cramer's $V=.138$ ) (Table 34) was found between the type of school (public/private) and survey question 26: Due to their lack of full-time 
commitment, adjunct faculty devote insufficient time and attention to their students. This small association was not significant.

Table 33

Crosstab

\begin{tabular}{|c|c|c|c|c|c|}
\hline \multirow[t]{2}{*}{ Q.26 } & \multirow{2}{*}{\multicolumn{2}{|c|}{$\begin{array}{l}\text { Due to their lack of full-time } \\
\text { commitment, adjunct faculty } \\
\text { devote insufficient time and } \\
\text { attention to their students }\end{array}$}} & \multicolumn{3}{|c|}{$\mathrm{C} 9=$ Public/Private Institutions } \\
\hline & & & Public & Private & Total \\
\hline & \multirow[t]{2}{*}{ Strongly disagree } & Count & 14 & 14 & 28 \\
\hline & & $\%$ within $\mathrm{C} 9$ & $23.3 \%$ & $29.8 \%$ & $26.2 \%$ \\
\hline & \multirow[t]{2}{*}{ Disagree } & Count & 30 & 23 & 53 \\
\hline & & $\%$ within C9 & $50.0 \%$ & $48.9 \%$ & $49.5 \%$ \\
\hline & \multirow[t]{2}{*}{ Not sure } & Count & 10 & 5 & 15 \\
\hline & & $\%$ within C9 & $16.7 \%$ & $10.6 \%$ & $14.0 \%$ \\
\hline & \multirow[t]{2}{*}{ Agree } & Count & 5 & 5 & 10 \\
\hline & & $\%$ within C9 & $8.3 \%$ & $10.6 \%$ & $9.3 \%$ \\
\hline & \multirow[t]{2}{*}{ Strongly agree } & Count & 1 & 0 & 1 \\
\hline & & $\%$ within C9 & $1.7 \%$ & $.0 \%$ & $.9 \%$ \\
\hline & \multirow[t]{2}{*}{ Total } & Count & 60 & 47 & 107 \\
\hline & & $\%$ within C9 & $100.0 \%$ & $100.0 \%$ & $100.0 \%$ \\
\hline
\end{tabular}

Table 34

Symmetric Measures

\begin{tabular}{|ll|r|r|}
\hline & & \multicolumn{1}{|c|}{ Value } & Approx. Sig. \\
\hline Nominal by Nominal & Phi & .138 & .728 \\
& Cramer's V & .138 & .728 \\
& N of Valid Cases & 107 & \\
\hline
\end{tabular}


Table 35 shows the answers to survey question 27 by providing descriptive statistics, frequencies, and percentages. A moderate association (Cramer's $V=.234)($ Table 36) was found between the type of school (public/private) and survey question 27: Not every adjunct is hired for reasons of cost; many are hired to meet special teaching needs. While there was a moderate association between the type of school and the reasons for hiring adjunct faculty, this association was not significant.

Table 35

\section{Crosstab}

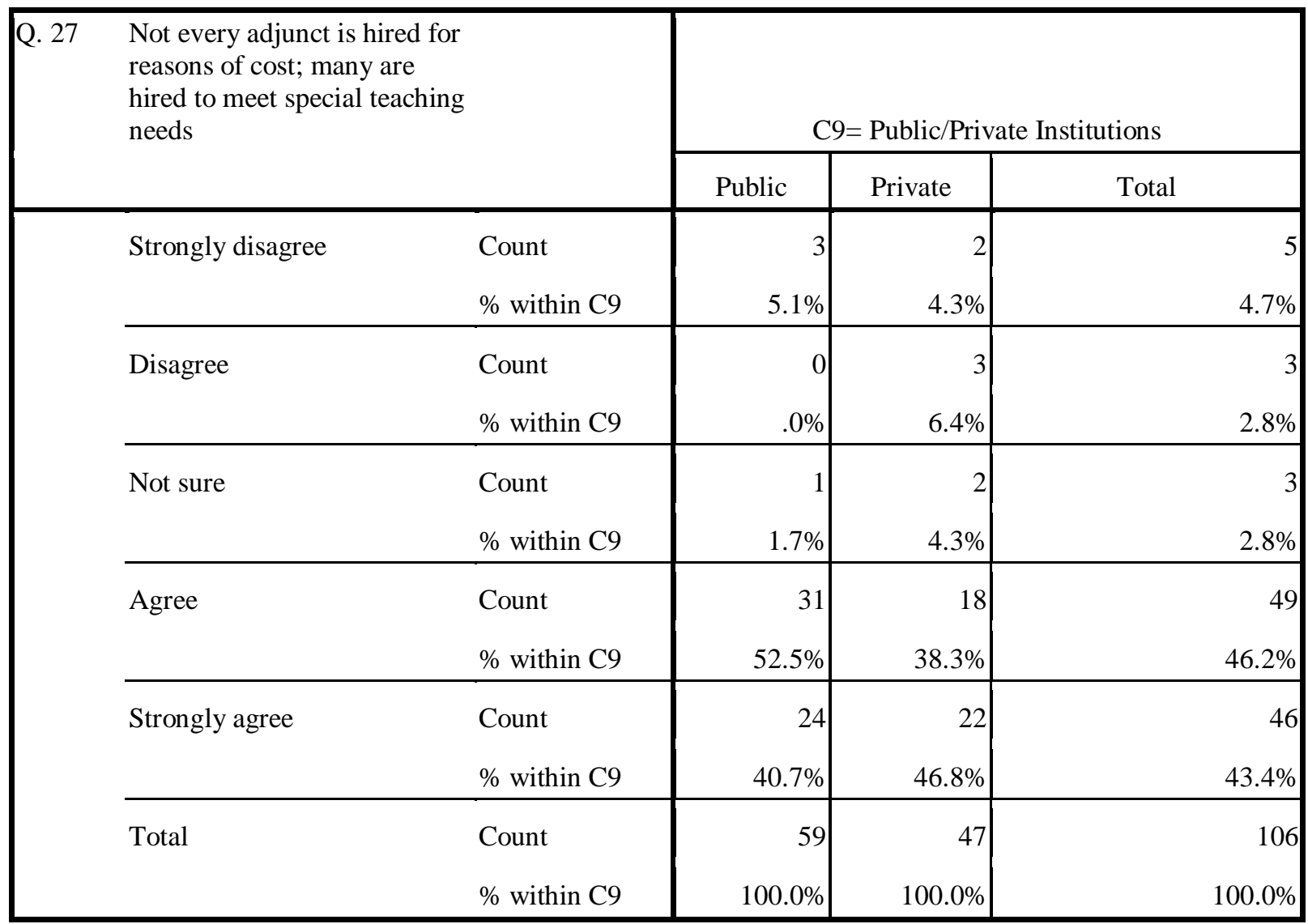


Table 36

Symmetric Measures

\begin{tabular}{|ll|r|r|}
\hline & & \multicolumn{1}{|c|}{ Value } & Approx. Sig. \\
\hline Nominal by Nominal & Phi & .234 & .216 \\
& Cramer's V & .234 & .216 \\
& N of Valid Cases & 106 & \\
\hline
\end{tabular}

Table 37 shows the answers to survey question 28 by providing descriptive statistics, frequencies, and percentages. A moderate association (Cramer's V =.218) (Table 38) was found between the type of school (public/private) and survey question 28: Adjunct faculty are often retained and reappointed over extended periods of time despite non-tenure-track instructional titles. While there was a moderate association between the type of school and concerns about whether adjunct faculty are retained and reappointed over extended periods of time despite nontenure-track instructional titles, this association was not significant. 
Table 37

Crosstab

\begin{tabular}{|c|c|c|c|c|c|}
\hline \multirow[t]{2}{*}{ Q. 28} & \multirow{2}{*}{\multicolumn{2}{|c|}{$\begin{array}{l}\text { Adjunct faculty are often } \\
\text { retained and reappointed over } \\
\text { extended periods of time } \\
\text { despite non-tenure-track } \\
\text { instructional titles }\end{array}$}} & \multicolumn{3}{|c|}{$\mathrm{C} 9=$ Public/Private Institutions } \\
\hline & & & Public & Private & Total \\
\hline & \multirow[t]{2}{*}{ Strongly disagree } & Count & 1 & 1 & 2 \\
\hline & & $\%$ within C9 & $1.7 \%$ & $2.1 \%$ & $1.9 \%$ \\
\hline & \multirow[t]{2}{*}{ Disagree } & Count & 6 & 2 & 8 \\
\hline & & $\%$ within C9 & $10.2 \%$ & $4.3 \%$ & $7.5 \%$ \\
\hline & \multirow[t]{2}{*}{ Not sure } & Count & 0 & 3 & 3 \\
\hline & & $\%$ within $\mathrm{C} 9$ & $.0 \%$ & $6.4 \%$ & $2.8 \%$ \\
\hline & \multirow[t]{2}{*}{ Agree } & Count & 30 & 23 & 53 \\
\hline & & $\%$ within C9 & $50.8 \%$ & $48.9 \%$ & $50.0 \%$ \\
\hline & \multirow[t]{2}{*}{ Strongly agree } & Count & 22 & 18 & 40 \\
\hline & & $\%$ within $\mathrm{C} 9$ & $37.3 \%$ & $38.3 \%$ & $37.7 \%$ \\
\hline & \multirow[t]{2}{*}{ Total } & Count & 59 & 47 & 106 \\
\hline & & $\%$ within $\mathrm{C} 9$ & $100.0 \%$ & $100.0 \%$ & $100.0 \%$ \\
\hline
\end{tabular}

Table 38

Symmetric Measures

\begin{tabular}{|ll|r|r|}
\hline & & \multicolumn{1}{|c|}{ Value } & Approx. Sig. \\
\hline Nominal by Nominal & Phi & .218 & .284 \\
& Cramer's V & .218 & .284 \\
& N of Valid Cases & 106 & \\
\hline
\end{tabular}

After descriptive statistics had been obtained for each survey item, an individual department chair's scores were summed across all survey items in a given area. For research question one, scores for items 17 through 28 were combined. The resulting composite scores 
were then averaged separately for chairs from private institutions and chairs from public institutions. These mean scores (Table 39) (public vs. private) were then compared for research question one using an ANOVA (Table 40).

Table 39

Descriptives: Research Question by Public/Private Institutions

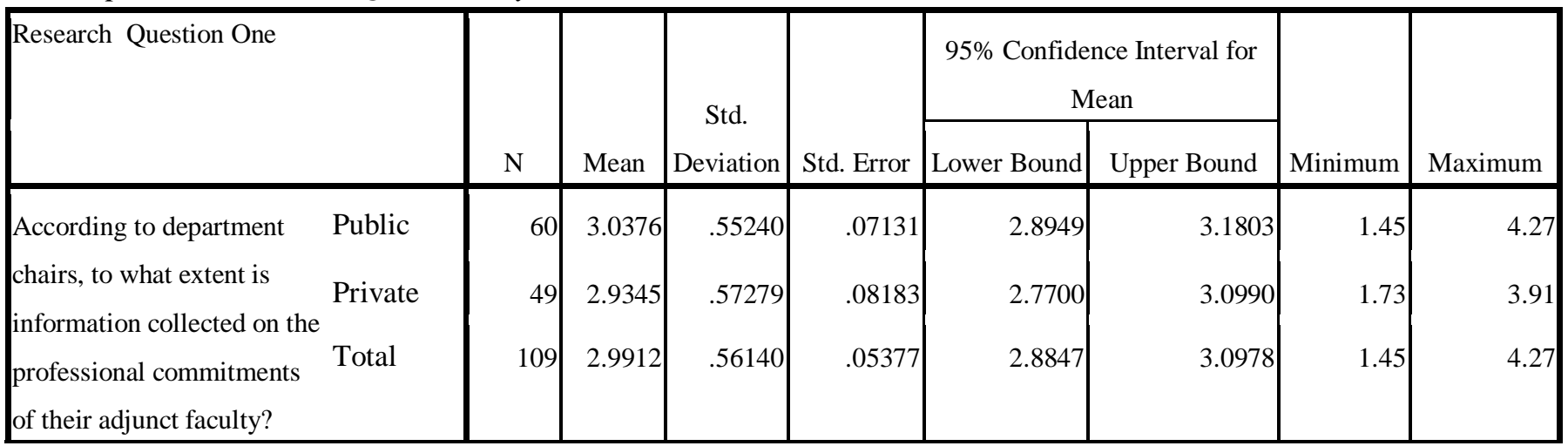

Conducting a One-Way ANOVA, there was no significant difference between chairs from public and those from private institutions on their composite scores in the area of information collected on the professional commitments of their adjunct faculty.

Table 40

ANOVA: Research Question by Public/Private Institutions

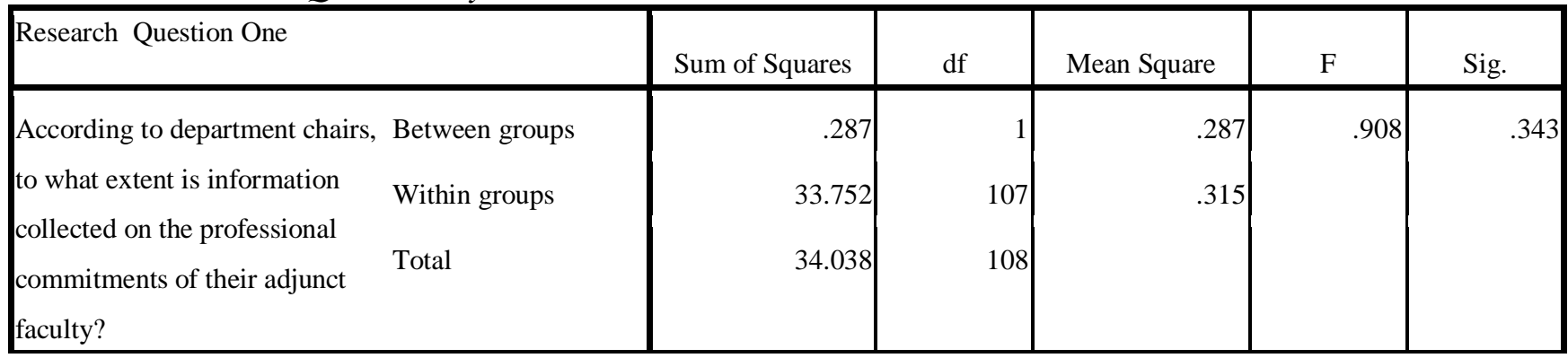

\section{Research Question Two}

The second research question asked: According to department chairs, to what extent are adjunct faculty evaluated and what evidence is required? This research question was answered 
by analyzing responses to survey questions 29 through 38 conducting a crosstab analysis. Table 41 shows the answers to survey question 29 by providing descriptive statistics, frequencies, and percentages. A moderate association (Cramer's V = .279) (Table 42) was found between the type of school (public/private) and survey question 29: Adjunct faculty should be evaluated the same as full time faculty. While there was a moderate association between the type of school and concerns about whether adjunct faculty should be evaluated the same as full time faculty, this association was not significant.

Table 41

Crosstab

\begin{tabular}{|c|c|c|c|c|c|}
\hline \multirow[t]{2}{*}{ Q. 29} & \multicolumn{2}{|c|}{$\begin{array}{l}\text { Adjunct faculty should be } \\
\text { evaluated the same as full time } \\
\text { faculty }\end{array}$} & \multicolumn{3}{|c|}{$\mathrm{C} 9=$ Public/Private Institutions } \\
\hline & & & Public & Private & Total \\
\hline & \multirow[t]{2}{*}{ Strongly disagree } & Count & 5 & 0 & 5 \\
\hline & & $\%$ within C9 & $8.5 \%$ & $.0 \%$ & $4.7 \%$ \\
\hline & \multirow[t]{2}{*}{ Disagree } & Count & 29 & 20 & 49 \\
\hline & & $\%$ within C9 & $49.2 \%$ & $41.7 \%$ & $45.8 \%$ \\
\hline & \multirow[t]{2}{*}{ Not sure } & Count & 3 & 5 & 8 \\
\hline & & $\%$ within C9 & $5.1 \%$ & $10.4 \%$ & $7.5 \%$ \\
\hline & \multirow[t]{2}{*}{ Agree } & Count & 17 & 13 & 30 \\
\hline & & $\%$ within C9 & $28.8 \%$ & $27.1 \%$ & $28.0 \%$ \\
\hline & \multirow[t]{2}{*}{ Strongly agree } & Count & 5 & 10 & 15 \\
\hline & & $\%$ within C9 & $8.5 \%$ & $20.8 \%$ & $14.0 \%$ \\
\hline & \multirow[t]{2}{*}{ Total } & Count & 59 & 48 & 107 \\
\hline & & $\%$ within $\mathrm{C} 9$ & $100.0 \%$ & $100.0 \%$ & $100.0 \%$ \\
\hline
\end{tabular}


Table 42

Symmetric Measures

\begin{tabular}{|ll|r|r|}
\hline & Value & $\begin{array}{c}\text { Approx. } \\
\text { Sig. }\end{array}$ \\
\hline $\begin{array}{llr}\text { Nominal by } \\
\text { Nominal }\end{array}$ & Phi & .279 & .081 \\
& Cramer's V & .279 & .081 \\
& N of Valid Cases & 107 & \\
\hline
\end{tabular}

Table 43 shows the answers to survey question 30 by providing descriptive statistics, frequencies, and percentages. A moderate association (Cramer's $V=.210$ ) (Table 44) was found between the type of school (public/private) and survey question 30: Adjunct faculty should be evaluated in the classroom by peer faculty members. While there was a moderate association between the type of school and concerns about whether adjunct faculty should be evaluated in the classroom by peer faculty members, this association was not significant. 
Table 43

\section{Crosstab}

\begin{tabular}{|c|c|c|c|c|c|}
\hline \multirow[t]{2}{*}{ Q.30 } & \multicolumn{2}{|c|}{$\begin{array}{l}\text { Adjunct faculty should be } \\
\text { evaluated in the classroom by } \\
\text { peer faculty members }\end{array}$} & \multicolumn{3}{|c|}{ C9= Public/Private Institutions } \\
\hline & & & Public & Private & Total \\
\hline & \multirow[t]{2}{*}{ Strongly disagree } & Count & 0 & 1 & 1 \\
\hline & & $\%$ within $\mathrm{C} 9$ & $.0 \%$ & $2.1 \%$ & $.9 \%$ \\
\hline & \multirow[t]{2}{*}{ Disagree } & Count & 7 & 4 & 11 \\
\hline & & $\%$ within $\mathrm{C} 9$ & $11.7 \%$ & $8.3 \%$ & $10.2 \%$ \\
\hline & \multirow[t]{2}{*}{ Not sure } & Count & 3 & 5 & 8 \\
\hline & & $\%$ within $\mathrm{C} 9$ & $5.0 \%$ & $10.4 \%$ & $7.4 \%$ \\
\hline & \multirow[t]{2}{*}{ Agree } & Count & 43 & 28 & 71 \\
\hline & & $\%$ within C9 & $71.7 \%$ & $58.3 \%$ & $65.7 \%$ \\
\hline & \multirow[t]{2}{*}{ Strongly agree } & Count & 7 & 10 & 17 \\
\hline & & $\%$ within C9 & $11.7 \%$ & $20.8 \%$ & $15.7 \%$ \\
\hline & \multirow[t]{2}{*}{ Total } & Count & 60 & 48 & 108 \\
\hline & & $\%$ within $\mathrm{C} 9$ & $100.0 \%$ & $100.0 \%$ & $100.0 \%$ \\
\hline
\end{tabular}

Table 44

Symmetric Measures

\begin{tabular}{|ll|r|r|}
\hline & & \multicolumn{1}{|c|}{ Value } & Approx. Sig. \\
\hline Nominal by Nominal & Phi & .210 & .315 \\
& Cramer's V & .210 & .315 \\
& N of Valid Cases & 108 & \\
\hline
\end{tabular}

Table 45 shows the answers to survey question 31 by providing descriptive statistics, frequencies, and percentages. A small association (Cramer's $V=.129$ ) (Table 46) was found between the type of school (public/private) and survey question 31: Adjunct faculty should be 
evaluated by Institutional student evaluations at the end of the class. This small association was not significant.

Table 45

Crosstab

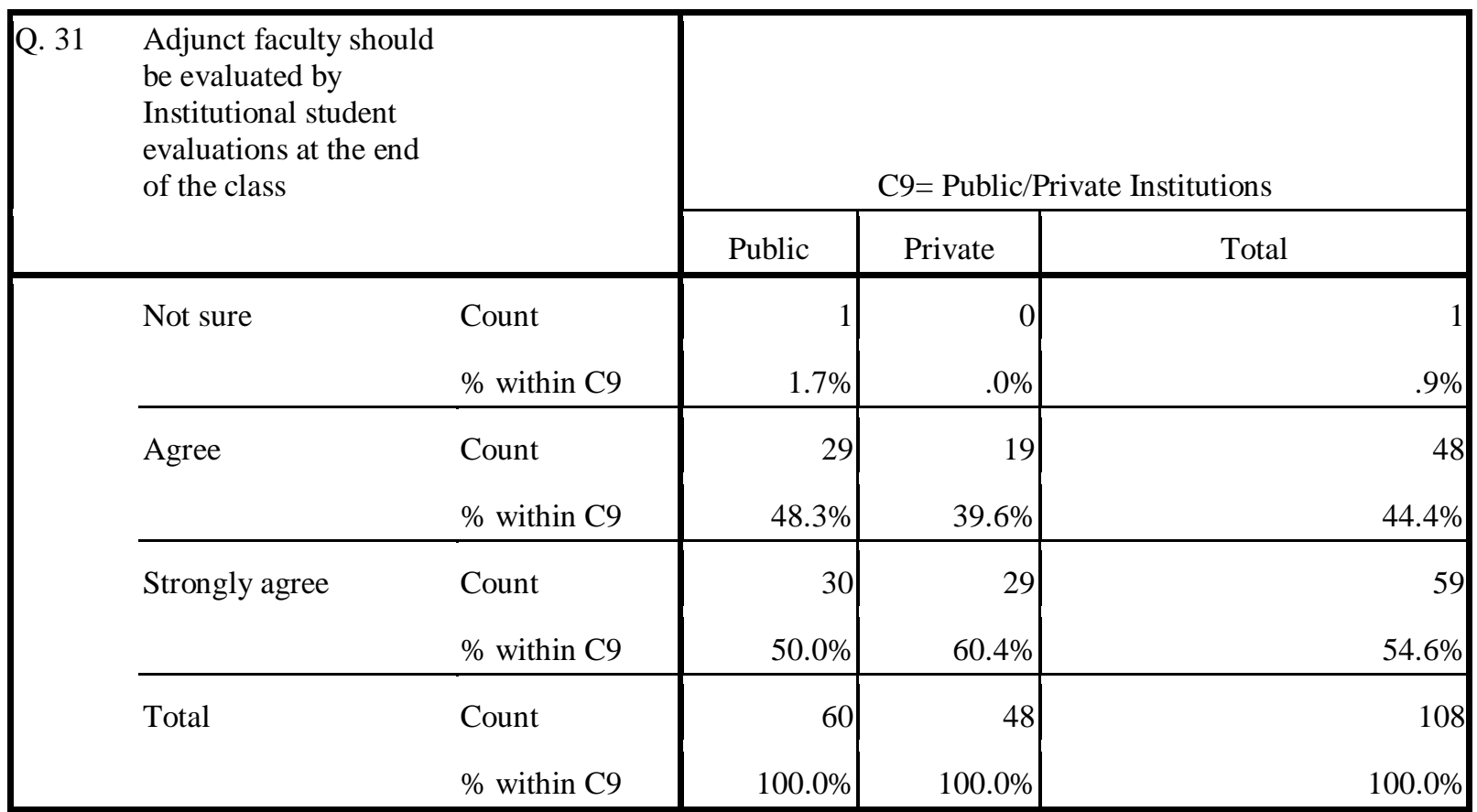

Table 46

Symmetric Measures

\begin{tabular}{|ll|r|r|}
\hline & & \multicolumn{1}{|c|}{ Value } & Approx. Sig. \\
\hline Nominal by Nominal & Phi & .129 & .409 \\
& Cramer's V & .129 & .409 \\
& N of Valid Cases & 108 & \\
\hline
\end{tabular}

Table 47 shows the answers to survey question 32 by providing descriptive statistics, frequencies, and percentages. A small association (Cramer's $V=.159$ ) (Table 48) was found between the type of school (public/private) and survey question 32: Adjunct faculty should be evaluated by department chairs only. This small association was not significant. 
Table 47

\section{Crosstab}

\begin{tabular}{|c|c|c|c|c|c|}
\hline \multirow[t]{2}{*}{ Q. 32} & \multicolumn{2}{|c|}{$\begin{array}{l}\text { Adjunct faculty should be } \\
\text { evaluated by department } \\
\text { chairs only }\end{array}$} & \multicolumn{3}{|c|}{$\mathrm{C} 9=$ Public/Private Institutions } \\
\hline & & & \multirow{3}{*}{$\begin{array}{r}\text { Public } \\
16 \\
26.7 \%\end{array}$} & \multirow{3}{*}{$\begin{array}{r}\text { Private } \\
8 \\
16.7 \% \\
\end{array}$} & \multirow{2}{*}{$\frac{\text { Total }}{24}$} \\
\hline & Strongly disagree & Count & & & \\
\hline & & $\%$ within C9 & & & $22.2 \%$ \\
\hline & Disagree & Count & 31 & 30 & 61 \\
\hline & & $\%$ within $\mathrm{C} 9$ & $51.7 \%$ & $62.5 \%$ & $56.5 \%$ \\
\hline & Not sure & Count & 7 & 5 & 12 \\
\hline & & $\%$ within $\mathrm{C} 9$ & $11.7 \%$ & $10.4 \%$ & $11.1 \%$ \\
\hline & Agree & Count & 5 & 5 & 10 \\
\hline & & $\%$ within C9 & $8.3 \%$ & $10.4 \%$ & $9.3 \%$ \\
\hline & Strongly agree & Count & 1 & 0 & 1 \\
\hline & & $\%$ within C9 & $1.7 \%$ & $.0 \%$ & $.9 \%$ \\
\hline & Total & Count & 60 & 48 & 108 \\
\hline & & $\%$ within C9 & $100.0 \%$ & $100.0 \%$ & $100.0 \%$ \\
\hline
\end{tabular}

Table 48

Symmetric Measures

\begin{tabular}{|ll|r|r|}
\hline & & \multicolumn{1}{|c|}{ Value } & Approx. Sig. \\
\hline Nominal by Nominal & Phi & .159 & .606 \\
& Cramer's V & .159 & .606 \\
& N of Valid Cases & 108 & \\
\hline
\end{tabular}

Table 49 shows the answers to survey question 33 by providing descriptive statistics, frequencies, and percentages. A small association (Cramer's $\mathrm{V}=.170$ ) (Table 50) was found between the type of school (public/private) and survey question 33: Evaluation of teaching effectiveness is mandatory. This small association was not significant. 
Table 49

\section{Crosstab}

\begin{tabular}{|c|c|c|c|c|c|}
\hline \multirow[t]{2}{*}{ Q 33} & \multicolumn{2}{|c|}{$\begin{array}{l}\text { Evaluation of teaching } \\
\text { effectiveness is } \\
\text { mandatory }\end{array}$} & \multicolumn{3}{|c|}{$\mathrm{C} 9=$ Public/Private Institutions } \\
\hline & & & Public & Private & Total \\
\hline & \multirow[t]{2}{*}{ Disagree } & Count & 3 & 0 & \\
\hline & & $\%$ within C9 & $5.0 \%$ & $.0 \%$ & $2.8 \%$ \\
\hline & \multirow[t]{2}{*}{ Not sure } & Count & 1 & 2 & \\
\hline & & $\%$ within C9 & $1.7 \%$ & $4.2 \%$ & $2.8 \%$ \\
\hline & \multirow[t]{2}{*}{ Agree } & Count & 30 & 26 & 56 \\
\hline & & $\%$ within C9 & $50.0 \%$ & $54.2 \%$ & $51.9 \%$ \\
\hline & \multirow[t]{2}{*}{ Strongly agree } & Count & 26 & 20 & 46 \\
\hline & & $\%$ within C9 & $43.3 \%$ & $41.7 \%$ & $42.6 \%$ \\
\hline & \multirow[t]{2}{*}{ Total } & Count & 60 & 48 & 108 \\
\hline & & $\%$ within $\mathrm{C} 9$ & $100.0 \%$ & $100.0 \%$ & $100.0 \%$ \\
\hline
\end{tabular}

Table 50

Symmetric Measures

\begin{tabular}{|ll|r|r|}
\hline & & \multicolumn{1}{|c|}{ Value } & Approx. Sig. \\
\hline Nominal by Nominal & Phi & .170 & .375 \\
& Cramer's V & .170 & .375 \\
& N of Valid Cases & 108 & \\
\hline
\end{tabular}

Table 51 shows the answers to survey question 34 by providing descriptive statistics, frequencies, and percentages. A small association (Cramer's $V=.100$ ) (Table 52) was found between the type of school (public/private) and survey question 34: Our institution has policies for formal evaluation of adjuncts. This small association was not significant. 
Table 51

Crosstab

\begin{tabular}{|c|c|c|c|c|c|}
\hline \multirow[t]{2}{*}{ Q. 34} & \multicolumn{2}{|c|}{$\begin{array}{l}\text { Our institution has policies } \\
\text { for formal evaluation of } \\
\text { adjuncts }\end{array}$} & \multicolumn{3}{|c|}{$\mathrm{C} 9=$ Public/Private Institutions } \\
\hline & & & Public & Private & Total \\
\hline & \multirow[t]{2}{*}{ Strongly disagree } & Count & 4 & 2 & 6 \\
\hline & & $\%$ within $\mathrm{C} 9$ & $6.7 \%$ & $4.2 \%$ & $5.6 \%$ \\
\hline & \multirow[t]{2}{*}{ Disagree } & Count & 17 & 15 & 32 \\
\hline & & $\%$ within $\mathrm{C} 9$ & $28.3 \%$ & $31.3 \%$ & $29.6 \%$ \\
\hline & \multirow[t]{2}{*}{ Not sure } & Count & 5 & 5 & 10 \\
\hline & & $\%$ within $\mathrm{C} 9$ & $8.3 \%$ & $10.4 \%$ & $9.3 \%$ \\
\hline & \multirow[t]{2}{*}{ Agree } & Count & 19 & 12 & 31 \\
\hline & & $\%$ within C9 & $31.7 \%$ & $25.0 \%$ & $28.7 \%$ \\
\hline & \multirow[t]{2}{*}{ Strongly agree } & Count & 15 & 14 & 29 \\
\hline & & $\%$ within $\mathrm{C} 9$ & $25.0 \%$ & $29.2 \%$ & $26.9 \%$ \\
\hline & \multirow[t]{2}{*}{ Total } & Count & 60 & 48 & 108 \\
\hline & & $\%$ within C9 & $100.0 \%$ & $100.0 \%$ & $100.0 \%$ \\
\hline
\end{tabular}

Table 52

Symmetric Measures

\begin{tabular}{|ll|r|r|}
\hline & & \multicolumn{1}{|c|}{ Value } & Approx. Sig. \\
\hline Nominal by Nominal & Phi & .100 & .896 \\
& Cramer's V & .100 & .896 \\
& N of Valid Cases & 108 & \\
\hline
\end{tabular}

Table 53 shows the answers to survey question 35 by providing descriptive statistics, frequencies, and percentages. A moderate association (Cramer's V = .277) (Table 54) was found between the type of school (public/private) and survey question 35: Adjunct faculty do evaluate themselves through informal methods. While there was a moderate association between the type 
of school and concerns about whether adjunct faculty evaluate themselves through informal methods, this association was not significant.

Table 53

Crosstab

\begin{tabular}{|c|c|c|c|c|c|}
\hline \multirow[t]{2}{*}{ Q. 35} & \multicolumn{2}{|c|}{$\begin{array}{l}\text { Adjunct faculty do evaluate } \\
\text { themselves through informal } \\
\text { methods }\end{array}$} & \multicolumn{3}{|c|}{$\mathrm{C} 9=$ Public/Private Institutions } \\
\hline & & & Public & Private & Total \\
\hline & \multirow[t]{2}{*}{ Strongly disagree } & Count & 2 & 1 & 3 \\
\hline & & $\%$ within C9 & $3.4 \%$ & $2.1 \%$ & $2.8 \%$ \\
\hline & \multirow[t]{2}{*}{ Disagree } & Count & 7 & 12 & 19 \\
\hline & & $\%$ within C9 & $12.1 \%$ & $25.0 \%$ & $17.9 \%$ \\
\hline & \multirow[t]{2}{*}{ Not sure } & Count & 29 & 12 & 41 \\
\hline & & $\%$ within C9 & $50.0 \%$ & $25.0 \%$ & $38.7 \%$ \\
\hline & \multirow[t]{2}{*}{ Agree } & Count & 18 & 20 & 38 \\
\hline & & $\%$ within C9 & $31.0 \%$ & $41.7 \%$ & $35.8 \%$ \\
\hline & \multirow[t]{2}{*}{ Strongly agree } & Count & 2 & 3 & 5 \\
\hline & & $\%$ within $\mathrm{C} 9$ & $3.4 \%$ & $6.3 \%$ & $4.7 \%$ \\
\hline & \multirow[t]{2}{*}{ Total } & Count & 58 & 48 & 106 \\
\hline & & $\%$ within C9 & $100.0 \%$ & $100.0 \%$ & $100.0 \%$ \\
\hline
\end{tabular}

Table 54

Symmetric Measures

\begin{tabular}{|ll|r|r|}
\hline & & \multicolumn{1}{|c|}{ Value } & Approx. Sig. \\
\hline Nominal by Nominal & Phi & .277 & .087 \\
& Cramer's V & .277 & .087 \\
& N of Valid Cases & 106 & \\
\hline
\end{tabular}

Table 55 shows the answers to survey question 36 by providing descriptive statistics, frequencies, and percentages. A small association (Cramer's $V=.109$ ) (Table 56) was found 
between the type of school (public/private) and survey question 36: Part-time, adjunct faculty are very effective teachers. This small association was not significant.

Table 55

Crosstab

\begin{tabular}{|ll|r|r|r|}
\hline Q.36 & \multicolumn{3}{|c|}{$\begin{array}{l}\text { Part-time, adjunct } \\
\text { faculty are very } \\
\text { effective teachers }\end{array}$} & \multicolumn{2}{|c|}{ C9= Public/Private Institutions } \\
\cline { 3 - 5 } & Public & Private & \multicolumn{1}{|c|}{ Total } \\
\hline Disagree & Count & 2 & 2 & 4 \\
& $\%$ within C9 & $3.4 \%$ & $4.2 \%$ & $3.7 \%$ \\
\hline Not sure & Count & 10 & 9 & 19 \\
& $\%$ within C9 & $16.9 \%$ & $18.8 \%$ & $17.8 \%$ \\
\hline Agree & Count & 41 & 29 & 70 \\
& $\%$ within C9 & $69.5 \%$ & $60.4 \%$ & $65.4 \%$ \\
\hline Strongly agree & Count & 6 & 8 & 14 \\
& $\%$ within C9 & $10.2 \%$ & $16.7 \%$ & $13.1 \%$ \\
\hline Total & Count & 59 & 48 & 107 \\
& $\%$ within C9 & $100.0 \%$ & $100.0 \%$ & $100.0 \%$ \\
\hline
\end{tabular}

Table 56

Symmetric Measures

\begin{tabular}{|ll|r|r|}
\hline & & \multicolumn{1}{|c|}{ Value } & Approx. Sig. \\
\hline Nominal by Nominal & Phi & .109 & .734 \\
& Cramer's V & .109 & .734 \\
& N of Valid Cases & 107 & \\
\hline
\end{tabular}

Table 57 shows the answers to survey question 37 by providing descriptive statistics, frequencies, and percentages. A small association (Cramer's V = .149) (Table 58) was found between the type of school (public/private) and survey question 37: Evaluations for adjunct 
faculty are consistently higher than for tenure-track faculty members. This small association was not significant.

Table 57

Crosstab

\begin{tabular}{|c|c|c|c|c|c|}
\hline \multirow[t]{2}{*}{ Q. 37} & \multirow{2}{*}{\multicolumn{2}{|c|}{$\begin{array}{l}\text { Evaluations for adjunct } \\
\text { faculty are consistently higher } \\
\text { than for tenure-track faculty } \\
\text { members }\end{array}$}} & \multicolumn{3}{|c|}{$\mathrm{C} 9=$ Public/Private Institutions } \\
\hline & & & Public & Private & Total \\
\hline & \multirow[t]{2}{*}{ Strongly disagree } & Count & 10 & 7 & 17 \\
\hline & & $\%$ within $\mathrm{C} 9$ & $16.7 \%$ & $14.6 \%$ & $15.7 \%$ \\
\hline & \multirow[t]{2}{*}{ Disagree } & Count & 41 & 28 & 69 \\
\hline & & $\%$ within C9 & $68.3 \%$ & $58.3 \%$ & $63.9 \%$ \\
\hline & \multirow[t]{2}{*}{ Not sure } & Count & 9 & 13 & 22 \\
\hline & & $\%$ within C9 & $15.0 \%$ & $27.1 \%$ & $20.4 \%$ \\
\hline & \multirow[t]{2}{*}{ Total } & Count & 60 & 48 & 108 \\
\hline & & $\%$ within C9 & $100.0 \%$ & $100.0 \%$ & $100.0 \%$ \\
\hline
\end{tabular}

Table 58

Symmetric Measures

\begin{tabular}{|ll|r|r|}
\hline & & \multicolumn{1}{|c|}{ Value } & Approx. Sig. \\
\hline Nominal by Nominal & Phi & .149 & .301 \\
& Cramer's V & .149 & .301 \\
& N of Valid Cases & 108 & \\
\hline
\end{tabular}

Table 59 shows the answers to survey question 38 by providing descriptive statistics, frequencies, and percentages. A small association (Cramer's $V=.106$ ) (Table 60) was found between the type of school (public/private) and survey question 38: The use of adjunct faculty will continue to grow in the future. This small association was not significant. 
Table 59

\section{Crosstab}

\begin{tabular}{|c|c|c|c|c|c|}
\hline \multirow[t]{2}{*}{ Q. 38} & \multicolumn{2}{|c|}{$\begin{array}{l}\text { The use of adjunct faculty } \\
\text { will continue to grow in the } \\
\text { future }\end{array}$} & \multicolumn{3}{|c|}{$\mathrm{C} 9=$ Public/Private Institutions } \\
\hline & & & Public & Private & Total \\
\hline & \multirow[t]{2}{*}{ Strongly disagree } & Count & 2 & 1 & 3 \\
\hline & & $\%$ within C9 & $3.3 \%$ & $2.1 \%$ & $2.8 \%$ \\
\hline & \multirow[t]{2}{*}{ Disagree } & Count & 5 & 3 & 8 \\
\hline & & $\%$ within $\mathrm{C} 9$ & $8.3 \%$ & $6.3 \%$ & $7.4 \%$ \\
\hline & \multirow[t]{2}{*}{ Not sure } & Count & 25 & 17 & 42 \\
\hline & & $\%$ within $\mathrm{C} 9$ & $41.7 \%$ & $35.4 \%$ & $38.9 \%$ \\
\hline & \multirow[t]{2}{*}{ Agree } & Count & 22 & 20 & 42 \\
\hline & & $\%$ within C9 & $36.7 \%$ & $41.7 \%$ & $38.9 \%$ \\
\hline & \multirow[t]{2}{*}{ Strongly agree } & Count & 6 & 7 & 13 \\
\hline & & $\%$ within C9 & $10.0 \%$ & $14.6 \%$ & $12.0 \%$ \\
\hline & \multirow[t]{2}{*}{ Total } & Count & 60 & 48 & 108 \\
\hline & & $\%$ within C9 & $100.0 \%$ & $100.0 \%$ & $100.0 \%$ \\
\hline
\end{tabular}

Table 60

Symmetric Measures

\begin{tabular}{|ll|r|r|}
\hline & & \multicolumn{1}{|c|}{ Value } & Approx. Sig. \\
\hline Nominal by Nominal & Phi & .106 & .876 \\
& Cramer's V & .106 & .876 \\
& N of Valid Cases & 108 & \\
\hline
\end{tabular}

After descriptive statistics had been obtained for each survey item, an individual department chair's scores were summed across all survey items in a given area. For research question two, scores for items 29 through 38 were combined. The resulting composite scores were then averaged separately for chairs from private institutions and those from public 
institutions. These mean scores (Table 61) (public vs. private) were then compared for research question two using an ANOVA.

Conducting a One-Way ANOVA, there was a significant difference $(p<.10)$ between chairs from public and those from private institutions on their composite scores in the area of the extent adjunct faculty are evaluated and what evidence is required (Table 62). Department chairs from private institutions recorded a higher mean score than department chairs from public institutions when asked about the extent adjunct faculty are evaluated and the evidence required.

Table 61

Descriptives: Research Question by Public/Private Institutions

\begin{tabular}{|c|c|c|c|c|c|c|c|c|c|}
\hline \multirow{2}{*}{\multicolumn{2}{|c|}{ Research Question Two }} & \multirow[b]{2}{*}{$\mathrm{N}$} & \multirow[b]{2}{*}{ Mean } & \multirow{2}{*}{$\begin{array}{c}\text { Std. } \\
\text { Deviatio } \\
\mathrm{n}\end{array}$} & \multirow[b]{2}{*}{ Std. Error } & \multicolumn{2}{|c|}{$\begin{array}{l}\text { 95\% Confidence Interval } \\
\text { for Mean }\end{array}$} & \multirow[b]{2}{*}{ Minimum } & \multirow[b]{2}{*}{ Maximum } \\
\hline & & & & & & $\begin{array}{l}\text { Lower } \\
\text { Bound }\end{array}$ & Upper Bound & & \\
\hline \multirow{3}{*}{$\begin{array}{l}\text { According to departmen } \\
\text { chairs, to what extent are } \\
\text { adjunct faculty evaluatec } \\
\text { and what evidence is } \\
\text { required? }\end{array}$} & Public & 60 & 3.3350 & .34146 & .04408 & 3.2468 & 3.4232 & 2.70 & 4.20 \\
\hline & Private & 48 & 3.4583 & .34260 & .04945 & 3.3589 & 3.5578 & 2.80 & 4.10 \\
\hline & Total & 108 & 3.3898 & .34589 & .03328 & 3.3238 & 3.4558 & 2.70 & 4.20 \\
\hline
\end{tabular}

Table 62

ANOVA: Research Question by Public/Private Institutions

\begin{tabular}{|c|c|c|c|c|c|c|}
\hline \multicolumn{2}{|l|}{ Research Question Two } & \multirow{3}{*}{$\begin{array}{r}\text { Sum of Squares } \\
.406 \\
12.396\end{array}$} & df & Mean Square & $\mathrm{F}$ & Sig. \\
\hline According to department & Between groups & & 1 & .406 & 3.469 & .065 \\
\hline chairs, to what extent are & Within groups & & 106 & .117 & & \\
\hline $\begin{array}{l}\text { adjunct faculty evaluated and } \\
\text { what evidence is required? }\end{array}$ & Total & 12.801 & 107 & & & \\
\hline
\end{tabular}




\section{Research Question Three}

The third research question asked: According to department chairs, to what extent do adjunct faculty become integrated into the department? This research question was answered by analyzing responses to survey questions 39 through 45 conducting a crosstab analysis. Table 63 shows the answers to survey question 39 by providing descriptive statistics, frequencies, and percentages. A small association (Cramer's $V=.164$ ) (Table 64) was found between the type of school (public/private) and survey question 39: Adjunct faculty understand the program's mission. This small association was not significant.

Table 63

Crosstab

\begin{tabular}{|c|c|c|c|c|c|}
\hline \multirow[t]{2}{*}{ Q. 39} & \multicolumn{2}{|c|}{$\begin{array}{l}\text { Adjunct faculty understand } \\
\text { the program's mission }\end{array}$} & \multicolumn{3}{|c|}{$\mathrm{C} 9=$ Public/Private Institutions } \\
\hline & & & Public & Private & Total \\
\hline & Strongly disagree & Count & 1 & 0 & 1 \\
\hline & & $\%$ within C9 & $1.7 \%$ & $.0 \%$ & $.9 \%$ \\
\hline & Disagree & Count & 7 & 5 & 12 \\
\hline & & $\%$ within C9 & $11.9 \%$ & $10.4 \%$ & $11.2 \%$ \\
\hline & Not sure & Count & 21 & 12 & 33 \\
\hline & & $\%$ within C9 & $35.6 \%$ & $25.0 \%$ & $30.8 \%$ \\
\hline & Agree & Count & 25 & 27 & 52 \\
\hline & & $\%$ within C9 & $42.4 \%$ & $56.3 \%$ & $48.6 \%$ \\
\hline & Strongly agree & Count & 5 & 4 & 9 \\
\hline & & $\%$ within C9 & $8.5 \%$ & $8.3 \%$ & $8.4 \%$ \\
\hline & Total & Count & 59 & 48 & 107 \\
\hline & & $\%$ within C9 & $100.0 \%$ & $100.0 \%$ & $100.0 \%$ \\
\hline
\end{tabular}


Table 64

Symmetric Measures

\begin{tabular}{|ll|r|r|}
\hline & & \multicolumn{1}{|c|}{ Value } & Approx. Sig. \\
\hline Nominal by Nominal & Phi & .164 & .579 \\
& Cramer's V & .164 & .579 \\
& N of Valid Cases & 107 & \\
\hline
\end{tabular}

Table 65 shows the answers to survey question 40 by providing descriptive statistics, frequencies, and percentages. A small association (Cramer's $V=.158$ ) (Table 66) was found between the type of school (public/private) and survey question 40: Adjunct faculty understand the program's learning outcomes. This small association was not significant.

Table 65

\section{Crosstab}

\begin{tabular}{|c|c|c|c|c|c|}
\hline \multirow[t]{2}{*}{ Q. 40} & \multicolumn{2}{|c|}{$\begin{array}{l}\text { Adjunct faculty understand } \\
\text { the program's learning } \\
\text { outcomes }\end{array}$} & \multicolumn{3}{|c|}{$\mathrm{C} 9=$ Public/Private Institutions } \\
\hline & & & Public & Private & Total \\
\hline & \multirow[t]{2}{*}{ Strongly disagree } & Count & 0 & 1 & 1 \\
\hline & & $\%$ within C9 & $.0 \%$ & $2.1 \%$ & $.9 \%$ \\
\hline & \multirow[t]{2}{*}{ Disagree } & Count & 7 & 4 & 11 \\
\hline & & $\%$ within $\mathrm{C} 9$ & $11.9 \%$ & $8.3 \%$ & $10.3 \%$ \\
\hline & \multirow[t]{2}{*}{ Not sure } & Count & 18 & 11 & 29 \\
\hline & & $\%$ within $\mathrm{C} 9$ & $30.5 \%$ & $22.9 \%$ & $27.1 \%$ \\
\hline & \multirow[t]{2}{*}{ Agree } & Count & 29 & 26 & 55 \\
\hline & & $\%$ within C9 & $49.2 \%$ & $54.2 \%$ & $51.4 \%$ \\
\hline & \multirow[t]{2}{*}{ Strongly agree } & Count & 5 & 6 & 11 \\
\hline & & $\%$ within C9 & $8.5 \%$ & $12.5 \%$ & $10.3 \%$ \\
\hline & \multirow[t]{2}{*}{ Total } & Count & 59 & 48 & 107 \\
\hline & & $\%$ within $\mathrm{C} 9$ & $100.0 \%$ & $100.0 \%$ & $100.0 \%$ \\
\hline
\end{tabular}


Table 66

Symmetric Measures

\begin{tabular}{|ll|l|l|}
\hline & & Value & Approx. Sig. \\
\hline Nominal by Nominal & Phi & .158 & .616 \\
& Cramer's V & .158 & .616 \\
& N of Valid Cases & 107 & \\
\hline
\end{tabular}

Table 67 shows the answers to survey question 41 by providing descriptive statistics, frequencies, and percentages. A small association (Cramer's $V=.127$ ) (Table 68) was found between the type of school (public/private) and survey question 41: Adjunct faculty understand how courses they teach fit into the appropriate academic programs. This small association was not significant. 
Table 67

\section{Crosstab}

\begin{tabular}{|c|c|c|c|c|c|}
\hline \multirow[t]{2}{*}{ Q. 41} & \multicolumn{2}{|c|}{$\begin{array}{l}\text { Adjunct faculty understand } \\
\text { how courses they teach fit } \\
\text { into the appropriate academic } \\
\text { programs }\end{array}$} & \multicolumn{3}{|c|}{$\mathrm{C} 9=$ Public/Private Institutions } \\
\hline & & & Public & Private & Total \\
\hline & \multirow[t]{2}{*}{ Strongly disagree } & Count & 1 & 2 & 3 \\
\hline & & $\%$ within C9 & $1.7 \%$ & $4.2 \%$ & $2.8 \%$ \\
\hline & \multirow[t]{2}{*}{ Disagree } & Count & 6 & 4 & 10 \\
\hline & & $\%$ within C9 & $10.2 \%$ & $8.3 \%$ & $9.3 \%$ \\
\hline & \multirow[t]{2}{*}{ Not sure } & Count & 14 & 8 & 22 \\
\hline & & $\%$ within C9 & $23.7 \%$ & $16.7 \%$ & $20.6 \%$ \\
\hline & \multirow[t]{2}{*}{ Agree } & Count & 32 & 30 & 62 \\
\hline & & $\%$ within C9 & $54.2 \%$ & $62.5 \%$ & $57.9 \%$ \\
\hline & \multirow[t]{2}{*}{ Strongly agree } & Count & 6 & 4 & 10 \\
\hline & & $\%$ within C9 & $10.2 \%$ & $8.3 \%$ & $9.3 \%$ \\
\hline & \multirow[t]{2}{*}{ Total } & Count & 59 & 48 & 107 \\
\hline & & $\%$ within C9 & $100.0 \%$ & $100.0 \%$ & $100.0 \%$ \\
\hline
\end{tabular}

Table 68

Symmetric Measures

\begin{tabular}{|lc|c|c|}
\hline & & Value & Approx. Sig. \\
\hline Nominal by Nominal & Phi & .127 & .787 \\
& Cramer's V & .127 & .787 \\
& N of Valid Cases & 107 & \\
\hline
\end{tabular}

Table 69 shows the answers to survey question 42 by providing descriptive statistics, frequencies, and percentages. No association (Cramer's $V=.089)$ (Table 70) was found between 
the type of school (public/private) and survey question 42: Students report that adjunct faculty are rarely available for advising.

Table 69

\section{Crosstab}

\begin{tabular}{|c|c|c|c|c|c|}
\hline \multirow[t]{2}{*}{ Q. 42} & \multicolumn{2}{|c|}{$\begin{array}{l}\text { Students report that adjunct } \\
\text { faculty are rarely available for } \\
\text { advising }\end{array}$} & \multicolumn{3}{|c|}{$\mathrm{C} 9=$ Public/Private Institutions } \\
\hline & & & Public & Private & Total \\
\hline & \multirow[t]{2}{*}{ Strongly disagree } & Count & 1 & 2 & 3 \\
\hline & & $\%$ within C9 & $1.7 \%$ & $4.3 \%$ & $2.8 \%$ \\
\hline & \multirow[t]{2}{*}{ Disagree } & Count & 36 & 28 & 64 \\
\hline & & $\%$ within C9 & $61.0 \%$ & $59.6 \%$ & $60.4 \%$ \\
\hline & \multirow[t]{2}{*}{ Not sure } & Count & 9 & 6 & 15 \\
\hline & & $\%$ within C9 & $15.3 \%$ & $12.8 \%$ & $14.2 \%$ \\
\hline & \multirow[t]{2}{*}{ Agree } & Count & 9 & 7 & 16 \\
\hline & & $\%$ within $\mathrm{C} 9$ & $15.3 \%$ & $14.9 \%$ & $15.1 \%$ \\
\hline & \multirow[t]{2}{*}{ Strongly agree } & Count & 4 & 4 & 8 \\
\hline & & $\%$ within C9 & $6.8 \%$ & $8.5 \%$ & $7.5 \%$ \\
\hline & \multirow[t]{2}{*}{ Total } & Count & 59 & 47 & 106 \\
\hline & & $\%$ within C9 & $100.0 \%$ & $100.0 \%$ & $100.0 \%$ \\
\hline
\end{tabular}

Table 70

Symmetric Measures

\begin{tabular}{|ll|r|r|}
\hline & & \multicolumn{1}{|c|}{ Value } & Approx. Sig. \\
\hline Nominal by Nominal & Phi & .089 & .934 \\
& Cramer's V & .089 & .934 \\
& N of Valid Cases & 106 & \\
\hline
\end{tabular}

Table 71 shows the answers to survey question 43 by providing descriptive statistics, frequencies, and percentages. A small association (Cramer's $V=.122$ ) (Table 72) was found 
between the type of school (public/private) and survey question 43: Adjunct faculty are included in planning discussions about current and projected course offerings. This small association was not significant.

Table 71

Crosstab

\begin{tabular}{|c|c|c|c|c|c|}
\hline \multirow[t]{2}{*}{ Q. 43} & \multirow{2}{*}{\multicolumn{2}{|c|}{$\begin{array}{l}\text { Adjunct faculty are } \\
\text { included in planning } \\
\text { discussions about current } \\
\text { and projected course } \\
\text { offerings }\end{array}$}} & \multicolumn{3}{|c|}{$\mathrm{C} 9=$ Public/Private Institutions } \\
\hline & & & PUBLIC & PRIVATE & Total \\
\hline & \multirow[t]{2}{*}{ Strondly disagree } & Count & 6 & 3 & \\
\hline & & $\%$ within C9 & $10.0 \%$ & $6.3 \%$ & $8.3 \%$ \\
\hline & \multirow[t]{2}{*}{ Disagree } & Count & 26 & 22 & 48 \\
\hline & & $\%$ within C9 & $43.3 \%$ & $45.8 \%$ & $44.4 \%$ \\
\hline & \multirow[t]{2}{*}{ Not sure } & Count & 2 & 3 & \\
\hline & & $\%$ within C9 & $3.3 \%$ & $6.3 \%$ & $4.6 \%$ \\
\hline & \multirow[t]{2}{*}{ Agree } & Count & 23 & 16 & 36 \\
\hline & & $\%$ within $\mathrm{C} 9$ & $38.3 \%$ & $33.3 \%$ & $36.1 \%$ \\
\hline & \multirow[t]{2}{*}{ Strongly agree } & Count & 3 & 4 & \\
\hline & & $\%$ within C9 & $5.0 \%$ & $8.3 \%$ & $6.5 \%$ \\
\hline & \multirow[t]{2}{*}{ Total } & Count & 60 & 48 & 108 \\
\hline & & $\%$ within $\mathrm{C} 9$ & $100.0 \%$ & $100.0 \%$ & $100.0 \%$ \\
\hline
\end{tabular}

Table 72

Symmetric Measures

\begin{tabular}{|ll|r|r|}
\hline & & \multicolumn{1}{|c|}{ Value } & Approx. Sig. \\
\hline Nominal by Nominal & Phi & .122 & .805 \\
& Cramer's V & .122 & .805 \\
& N of Valid Cases & 108 & \\
\hline
\end{tabular}


Table 73 shows the answers to survey question 44 by providing descriptive statistics, frequencies, and percentages. A moderate association (Cramer's $V=.202$ ) (Table 74) was found between the type of school (public/private) and survey question 44: Adjunct faculty are included in planning discussions about current and projected use of resource allocations, budget projections, and actual and anticipated sources of revenue. While there was a moderate association between the type of school and concerns about whether adjunct faculty are included in planning discussions about current and projected use of resource allocations, budget projections, and actual and anticipated sources of revenue, this association was not significant.

Table 73

Crosstab

\begin{tabular}{|c|c|c|c|c|c|}
\hline \multirow[t]{2}{*}{ Q. 44} & \multirow{2}{*}{\multicolumn{2}{|c|}{$\begin{array}{l}\text { Adjunct faculty are included } \\
\text { in planning discussions about } \\
\text { current and projected use of } \\
\text { resource allocations, budget } \\
\text { projections, and actual and } \\
\text { anticipated sources of } \\
\text { revenue }\end{array}$}} & \multicolumn{3}{|c|}{$\mathrm{C} 9=$ Public/Private Institutions } \\
\hline & & & Public & Private & Total \\
\hline & \multirow[t]{2}{*}{ Strongly disagree } & Count & 13 & 11 & 24 \\
\hline & & $\%$ within C9 & $21.7 \%$ & $23.4 \%$ & $22.4 \%$ \\
\hline & \multirow[t]{2}{*}{ Disagree } & Count & 31 & 22 & 53 \\
\hline & & $\%$ within C9 & $51.7 \%$ & $46.8 \%$ & $49.5 \%$ \\
\hline & \multirow[t]{2}{*}{ Not sure } & Count & 1 & 5 & 6 \\
\hline & & $\%$ within C9 & $1.7 \%$ & $10.6 \%$ & $5.6 \%$ \\
\hline & \multirow[t]{2}{*}{ Agree } & Count & 13 & 8 & 21 \\
\hline & & $\%$ within C9 & $21.7 \%$ & $17.0 \%$ & $19.6 \%$ \\
\hline & \multirow[t]{2}{*}{ Strongly agree } & Count & 2 & 1 & 3 \\
\hline & & $\%$ within C9 & $3.3 \%$ & $2.1 \%$ & $2.8 \%$ \\
\hline & \multirow[t]{2}{*}{ Total } & Count & 60 & 47 & 107 \\
\hline & & $\%$ within C9 & $100.0 \%$ & $100.0 \%$ & $100.0 \%$ \\
\hline
\end{tabular}


Table 74

Symmetric Measures

\begin{tabular}{|ll|r|r|}
\hline & & \multicolumn{1}{|c|}{ Value } & Approx. Sig. \\
\hline Nominal by Nominal & Phi & .202 & .358 \\
& Cramer's V & .202 & .358 \\
& N of Valid Cases & 107 & \\
\hline
\end{tabular}

Table 75 shows the answers to survey question 4 by providing descriptive statistics, frequencies, and percentages. A small association (Cramer's $V=.189$ ) (Table 76) was found between the type of school (public/private) and survey question 45: Adjunct faculty are included in the formulation of strategies and plans that reflect the mission and educational objectives of the department and institution. This small association was not significant. 
Table 75

\section{Crosstab}

\begin{tabular}{|c|c|c|c|c|c|}
\hline \multirow[t]{2}{*}{ Q. 45} & \multirow{2}{*}{\multicolumn{2}{|c|}{$\begin{array}{l}\text { Adjunct faculty are included } \\
\text { in the formulation of } \\
\text { strategies and plans that } \\
\text { reflect the mission and } \\
\text { educational objectives of the } \\
\text { department and institution }\end{array}$}} & \multicolumn{3}{|c|}{$\mathrm{C} 9=$ Public/Private Institutions } \\
\hline & & & Public & Private & Total \\
\hline & \multirow[t]{2}{*}{ Strongly disagree } & Count & 13 & 6 & 19 \\
\hline & & $\%$ within C9 & $21.7 \%$ & $12.5 \%$ & $17.6 \%$ \\
\hline & \multirow[t]{2}{*}{ Disagree } & Count & 24 & 20 & 44 \\
\hline & & $\%$ within C9 & $40.0 \%$ & $41.7 \%$ & $40.7 \%$ \\
\hline & \multirow[t]{2}{*}{ Not sure } & Count & 1 & 1 & 2 \\
\hline & & $\%$ within $\mathrm{C} 9$ & $1.7 \%$ & $2.1 \%$ & $1.9 \%$ \\
\hline & \multirow[t]{2}{*}{ Agree } & Count & 21 & 17 & 38 \\
\hline & & $\%$ within $\mathrm{C} 9$ & $35.0 \%$ & $35.4 \%$ & $35.2 \%$ \\
\hline & \multirow[t]{2}{*}{ Strongly agree } & Count & 1 & 4 & \\
\hline & & $\%$ within C9 & $1.7 \%$ & $8.3 \%$ & $4.6 \%$ \\
\hline & \multirow[t]{2}{*}{ Total } & Count & 60 & 48 & 108 \\
\hline & & $\%$ within $\mathrm{C} 9$ & $100.0 \%$ & $100.0 \%$ & $100.0 \%$ \\
\hline
\end{tabular}

Table 76

Symmetric Measures

\begin{tabular}{|ll|r|r|}
\hline & & \multicolumn{1}{|c|}{ Value } & Approx. Sig. \\
\hline Nominal by Nominal & Phi & .189 & .423 \\
& Cramer's V & .189 & .423 \\
& N of Valid Cases & 108 & \\
\hline
\end{tabular}

After descriptive statistics had been obtained for each survey item, an individual department chair's scores were summed across all survey items in a given area. For research question three, scores for survey items 39 through 45 were combined. The resulting composite 
scores were then averaged separately for chairs from private institutions and chairs from public institutions. These mean scores (Table 77) (public vs. private) were then compared for research question three using an ANOVA.

Table 77

Descriptives: Research Question by Public/Private Institutions

\begin{tabular}{|c|c|c|c|c|c|c|c|c|c|}
\hline & \multirow[t]{2}{*}{$\begin{array}{l}\text { Research Question } \\
\text { Three }\end{array}$} & \multirow[b]{2}{*}{$\mathrm{N}$} & \multirow[b]{2}{*}{ Mean } & \multirow{2}{*}{$\begin{array}{c}\text { Std. } \\
\text { Deviatio } \\
\mathbf{n}\end{array}$} & \multirow[b]{2}{*}{ Std. Error } & \multicolumn{2}{|c|}{$\begin{array}{l}\text { 95\% Confidence Interval } \\
\text { for Mean }\end{array}$} & \multirow[b]{2}{*}{ Minimum } & \multirow[b]{2}{*}{ Maximum } \\
\hline & & & & & & Bound & Upper Bound & & \\
\hline $\begin{array}{l}\text { chairs, to what extent do } \\
\text { adjunct faculty become }\end{array}$ & Private & 48 & 3.0923 & .61497 & .08876 & 2.9137 & 3.2708 & 1.71 & 4.43 \\
\hline $\begin{array}{l}\text { integrated into the } \\
\text { department? }\end{array}$ & Total & 108 & 3.0335 & .62598 & .06024 & 2.9141 & 3.1529 & 1.57 & 4.57 \\
\hline
\end{tabular}

Conducting a One-Way ANOVA, there was no significant difference (Table 78) between chairs from public and those from private institutions on their composite scores in the area of adjunct faculty becoming integrated into the department.

Table 78

ANOVA: Research Question by Public/Private Institutions

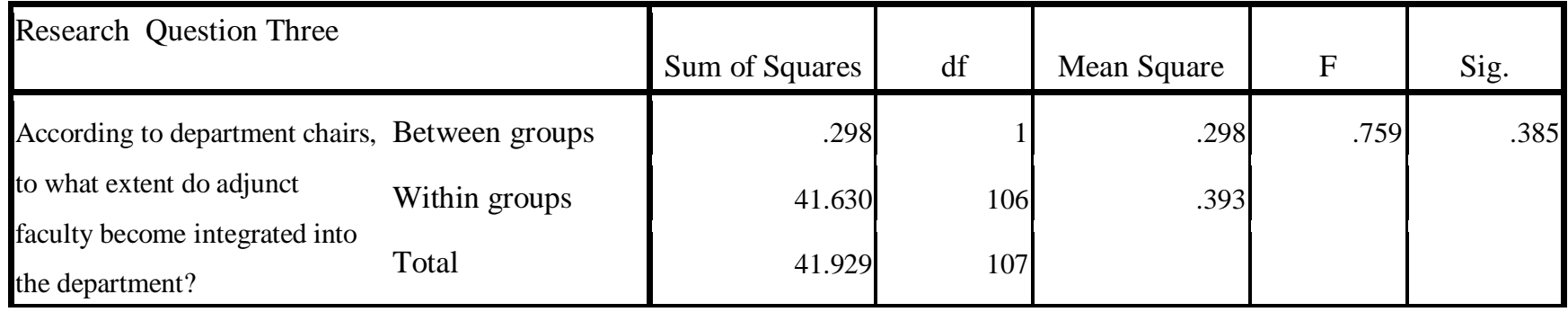




\section{Research Question Four}

The forth research question asked: According to department chairs, to what extent are performance expectations explained to adjunct faculty? This research question was answered by analyzing responses to survey questions 46 through 56 conducting a crosstab analysis. Table 79 shows the answers to survey question 46 by providing descriptive statistics, frequencies, and percentages. A moderate association (Cramer's $V=.242)$ (Table 80$)$ was found between the type of school (public/private) and survey question 46: Adjunct faculty are expected to maintain regular office hours. While there was a moderate association between the type of school and concerns about whether adjunct faculty expected to maintain regular office hours, this association was not significant.

Table 79

\section{Crosstab}

\begin{tabular}{|c|c|c|c|c|c|}
\hline \multirow[t]{2}{*}{ Q. 46} & \multicolumn{2}{|c|}{$\begin{array}{l}\text { Adjunct faculty are expected } \\
\text { to maintain regular office } \\
\text { hours }\end{array}$} & \multicolumn{3}{|c|}{$\mathrm{C} 9=$ Public/Private Institutions } \\
\hline & & & Public & Private & Total \\
\hline & \multirow[t]{2}{*}{ Strongly disagree } & Count & 0 & 4 & \\
\hline & & $\%$ within C9 & $.0 \%$ & $8.3 \%$ & $3.7 \%$ \\
\hline & \multirow[t]{2}{*}{ Disagree } & Count & 13 & 10 & 23 \\
\hline & & $\%$ within C9 & $21.7 \%$ & $20.8 \%$ & $21.3 \%$ \\
\hline & \multirow[t]{2}{*}{ Not sure } & Count & 1 & 2 & 3 \\
\hline & & $\%$ within C9 & $1.7 \%$ & $4.2 \%$ & $2.8 \%$ \\
\hline & \multirow[t]{2}{*}{ Agree } & Count & 33 & 21 & 54 \\
\hline & & $\%$ within C9 & $55.0 \%$ & $43.8 \%$ & $50.0 \%$ \\
\hline & \multirow[t]{2}{*}{ Strongly agree } & Count & 13 & 11 & 24 \\
\hline & & $\%$ within C9 & $21.7 \%$ & $22.9 \%$ & $22.2 \%$ \\
\hline & \multirow[t]{2}{*}{ Total } & Count & 60 & 48 & 108 \\
\hline & & $\%$ within C9 & $100.0 \%$ & $100.0 \%$ & $100.0 \%$ \\
\hline
\end{tabular}


Table 80

Symmetric Measures

\begin{tabular}{|ll|r|r|}
\hline & & \multicolumn{1}{|c|}{ Value } & Approx. Sig. \\
\hline Nominal by Nominal & Phi & .242 & .178 \\
& Cramer's V & .242 & .178 \\
& N of Valid Cases & 108 & \\
\hline
\end{tabular}

Table 81 shows the answers to survey question 47 by providing descriptive statistics, frequencies, and percentages. A moderate association (Cramer's V =.213) (Table 82) was found between the type of school (public/private) and survey question 47: Adjunct faculty are expected to serve as an advisor to students. While there was a moderate association between the type of school and concerns about whether adjunct faculty members are expected to serve as an advisor to students, this association was not significant. 
Table 81

\section{Crosstab}

\begin{tabular}{|c|c|c|c|c|c|}
\hline \multirow[t]{2}{*}{ Q. 47} & \multicolumn{2}{|c|}{$\begin{array}{l}\text { Adjunct faculty are expected } \\
\text { to serve as an advisor to } \\
\text { students }\end{array}$} & \multicolumn{3}{|c|}{$\mathrm{C} 9=$ Public/Private Institutions } \\
\hline & & & Public & Private & Total \\
\hline & \multirow[t]{2}{*}{ Strongly disagree } & Count & 16 & 15 & 31 \\
\hline & & $\%$ within C9 & $26.7 \%$ & $31.3 \%$ & $28.7 \%$ \\
\hline & \multirow[t]{2}{*}{ Disagree } & Count & 39 & 23 & 62 \\
\hline & & $\%$ within C9 & $65.0 \%$ & $47.9 \%$ & $57.4 \%$ \\
\hline & \multirow[t]{2}{*}{ Not sure } & Count & 1 & 3 & 4 \\
\hline & & $\%$ within C9 & $1.7 \%$ & $6.3 \%$ & $3.7 \%$ \\
\hline & \multirow[t]{2}{*}{ Agree } & Count & 3 & 6 & 9 \\
\hline & & $\%$ within C9 & $5.0 \%$ & $12.5 \%$ & $8.3 \%$ \\
\hline & \multirow[t]{2}{*}{ Strongly agree } & Count & 1 & 1 & 2 \\
\hline & & $\%$ within C9 & $1.7 \%$ & $2.1 \%$ & $1.9 \%$ \\
\hline & \multirow[t]{2}{*}{ Total } & Count & 60 & 48 & 108 \\
\hline & & $\%$ within $\mathrm{C} 9$ & $100.0 \%$ & $100.0 \%$ & $100.0 \%$ \\
\hline
\end{tabular}

Table 82

Symmetric Measures

\begin{tabular}{|ll|r|r|}
\hline & & \multicolumn{1}{|c|}{ Value } & Approx. Sig. \\
\hline Nominal by Nominal & Phi & .213 & .299 \\
& Cramer's V & .213 & .299 \\
& N of Valid Cases & 108 & \\
\hline
\end{tabular}

Table 83 shows the answers to survey question 48 by providing descriptive statistics, frequencies, and percentages. A moderate association (Cramer's V $=.225$ ) (Table 84) was found between the type of school (public/private) and survey question 48: Adjunct faculty are expected to develop their course syllabi. While there was a moderate association between the type of 
school and concerns about whether adjunct faculty members are expected to develop their course syllabi, this association was not significant.

Table 83

Crosstab

\begin{tabular}{|c|c|c|c|c|c|}
\hline \multirow[t]{2}{*}{ Q. 48} & \multicolumn{2}{|c|}{$\begin{array}{l}\text { Adjunct faculty are expected } \\
\text { to develop their course syllabi }\end{array}$} & \multicolumn{3}{|c|}{$\mathrm{C} 9=$ Public/Private Institutions } \\
\hline & & & Public & Private & Total \\
\hline & \multirow[t]{2}{*}{ Strongly disagree } & Count & 3 & 1 & \\
\hline & & $\%$ within C9 & $5.2 \%$ & $2.1 \%$ & $3.8 \%$ \\
\hline & \multirow[t]{2}{*}{ Disagree } & Count & 11 & 4 & 15 \\
\hline & & $\%$ within C9 & $19.0 \%$ & $8.5 \%$ & $14.3 \%$ \\
\hline & \multirow[t]{2}{*}{ Not sure } & Count & 2 & 2 & \\
\hline & & $\%$ within C9 & $3.4 \%$ & $4.3 \%$ & $3.8 \%$ \\
\hline & \multirow[t]{2}{*}{ Agree } & Count & 24 & 29 & 53 \\
\hline & & $\%$ within C9 & $41.4 \%$ & $61.7 \%$ & $50.5 \%$ \\
\hline & \multirow[t]{2}{*}{ Strongly agree } & Count & 18 & 11 & 29 \\
\hline & & $\%$ within C9 & $31.0 \%$ & $23.4 \%$ & $27.6 \%$ \\
\hline & \multirow[t]{2}{*}{ Total } & Count & 58 & 47 & 105 \\
\hline & & $\%$ within C9 & $100.0 \%$ & $100.0 \%$ & $100.0 \%$ \\
\hline
\end{tabular}

Table 84

Symmetric Measures

\begin{tabular}{|ll|r|r|}
\hline & & \multicolumn{1}{|c|}{ Value } & Approx. Sig. \\
\hline Nominal by Nominal & Phi & .225 & .255 \\
& Cramer's V & .225 & .255 \\
& N of Valid Cases & 105 & \\
\hline
\end{tabular}

Table 85 shows the answers to survey question 49 by providing descriptive statistics, frequencies, and percentages. A moderate association (Cramer's V =.245) (Table 86) was found between the type of school (public/private) and survey question 49: Adjunct faculty are expected 
to conduct assessments of student learning. While there was a moderate association between the type of school and concerns about whether adjunct faculty are expected to conduct assessments of student learning, this association was not significant.

Table 85

\section{Crosstab}

\begin{tabular}{|c|c|c|c|c|c|}
\hline \multirow[t]{2}{*}{ Q. 49} & \multicolumn{2}{|c|}{$\begin{array}{l}\text { Adjunct faculty are expected } \\
\text { to conduct assessments of } \\
\text { student learning }\end{array}$} & \multicolumn{3}{|c|}{$\mathrm{C} 9=$ Public/Private Institutions } \\
\hline & & & Public & Private & Total \\
\hline & \multirow[t]{2}{*}{ Strongly disagree } & Count & 0 & 2 & 2 \\
\hline & & $\%$ within $\mathrm{C} 9$ & $.0 \%$ & $4.2 \%$ & $1.9 \%$ \\
\hline & \multirow[t]{2}{*}{ Disagree } & Count & 8 & 2 & 10 \\
\hline & & $\%$ within C9 & $13.6 \%$ & $4.2 \%$ & $9.3 \%$ \\
\hline & \multirow[t]{2}{*}{ Not sure } & Count & 1 & 3 & 4 \\
\hline & & $\%$ within $\mathrm{C} 9$ & $1.7 \%$ & $6.3 \%$ & $3.7 \%$ \\
\hline & \multirow[t]{2}{*}{ Agree } & Count & 36 & 30 & 66 \\
\hline & & $\%$ within C9 & $61.0 \%$ & $62.5 \%$ & $61.7 \%$ \\
\hline & \multirow[t]{2}{*}{ Strongly agree } & Count & 14 & 11 & 25 \\
\hline & & $\%$ within $\mathrm{C} 9$ & $23.7 \%$ & $22.9 \%$ & $23.4 \%$ \\
\hline & \multirow[t]{2}{*}{ Total } & Count & 59 & 48 & 107 \\
\hline & & $\%$ within $\mathrm{C} 9$ & $100.0 \%$ & $100.0 \%$ & $100.0 \%$ \\
\hline
\end{tabular}

Table 86

Symmetric Measures

\begin{tabular}{|ll|r|r|}
\hline & & \multicolumn{1}{|c|}{ Value } & Approx. Sig. \\
\hline Nominal by Nominal & Phi & .245 & .168 \\
& Cramer's V & .245 & .168 \\
& N of Valid Cases & 107 & \\
\hline
\end{tabular}


Table 87 shows the answers to survey question 50 by providing descriptive statistics, frequencies, and percentages. A strong association (Cramer's $\mathrm{V}=.317, p<.05)$ (Table 88) was found between the type of school (public/private) and survey question 50: Adjunct faculty are expected to use student-centered effective teaching techniques. This association was significant.

Table 87

\section{Crosstab}

\begin{tabular}{|c|c|c|c|c|c|}
\hline \multirow[t]{2}{*}{ Q. 50 } & \multicolumn{2}{|c|}{$\begin{array}{l}\text { Adjunct faculty are } \\
\text { expected to use student- } \\
\text { centered effective teaching } \\
\text { techniques }\end{array}$} & \multicolumn{3}{|c|}{ C9 =Public/Private Institutions } \\
\hline & & & Public & Private & Total \\
\hline & \multirow[t]{2}{*}{ Strongly disagree } & Count & 0 & 1 & 1 \\
\hline & & $\%$ within C9 & $.0 \%$ & $2.1 \%$ & $.9 \%$ \\
\hline & \multirow[t]{2}{*}{ Disagree } & Count & 5 & 1 & 6 \\
\hline & & $\%$ within C9 & $8.6 \%$ & $2.1 \%$ & $5.7 \%$ \\
\hline & \multirow[t]{2}{*}{ Not sure } & Count & 2 & 9 & 11 \\
\hline & & $\%$ within C9 & $3.4 \%$ & $18.8 \%$ & $10.4 \%$ \\
\hline & \multirow[t]{2}{*}{ Agree } & Count & 41 & 26 & 67 \\
\hline & & $\%$ within C9 & $70.7 \%$ & $54.2 \%$ & $63.2 \%$ \\
\hline & \multirow[t]{2}{*}{ Strongly agree } & Count & 10 & 11 & 21 \\
\hline & & $\%$ within C9 & $17.2 \%$ & $22.9 \%$ & $19.8 \%$ \\
\hline & \multirow[t]{2}{*}{ Total } & Count & 58 & 48 & 106 \\
\hline & & $\%$ within C9 & $100.0 \%$ & $100.0 \%$ & $100.0 \%$ \\
\hline
\end{tabular}

Table 88

Symmetric Measures

\begin{tabular}{|ll|r|r|}
\hline & \multicolumn{1}{|c|}{ Value } & Approx. Sig. \\
\hline Nominal by Nominal & Phi & .317 & .030 \\
& Cramer's V & .317 & .030 \\
& N of Valid Cases & 106 & \\
\hline
\end{tabular}


Table 89 shows the answers to survey question 51 by providing descriptive statistics, frequencies, and percentages. A moderate association (Cramer's $V=.282$ ) (Table 90) was found between the type of school (public/private) and survey question 51: Adjunct faculty are expected to engage in and publish research. While there was a moderate association between the type of school and concerns about whether adjunct faculty members are expected to engage in and publish research, this association was not significant.

Table 89

\section{Crosstab}

\begin{tabular}{|c|c|c|c|c|c|}
\hline \multirow[t]{2}{*}{ Q. 51} & \multicolumn{2}{|c|}{$\begin{array}{l}\text { Adjunct faculty are expected } \\
\text { to engage in and publish } \\
\text { research }\end{array}$} & \multicolumn{3}{|c|}{ C9 =Public/Private Institutions } \\
\hline & & & Public & Private & Total \\
\hline & \multirow[t]{2}{*}{ Strongly disagree } & Count & 23 & 19 & 42 \\
\hline & & $\%$ within C9 & $39.0 \%$ & $39.6 \%$ & $39.3 \%$ \\
\hline & \multirow[t]{2}{*}{ Disagree } & Count & 32 & 19 & 51 \\
\hline & & $\%$ within C9 & $54.2 \%$ & $39.6 \%$ & $47.7 \%$ \\
\hline & \multirow[t]{2}{*}{ Not sure } & Count & 3 & 2 & 5 \\
\hline & & $\%$ within C9 & $5.1 \%$ & $4.2 \%$ & $4.7 \%$ \\
\hline & \multirow[t]{2}{*}{ Agree } & Count & 1 & 5 & 6 \\
\hline & & $\%$ within $\mathrm{C} 9$ & $1.7 \%$ & $10.4 \%$ & $5.6 \%$ \\
\hline & \multirow[t]{2}{*}{ Strongly agree } & Count & 0 & 3 & 3 \\
\hline & & $\%$ within C9 & $.0 \%$ & $6.3 \%$ & $2.8 \%$ \\
\hline & \multirow[t]{2}{*}{ Total } & Count & 59 & 48 & 107 \\
\hline & & $\%$ within C9 & $100.0 \%$ & $100.0 \%$ & $100.0 \%$ \\
\hline
\end{tabular}


Table 90

Symmetric Measures

\begin{tabular}{|ll|r|r|}
\hline & & \multicolumn{1}{|c|}{ Value } & Approx. Sig. \\
\hline Nominal by Nominal & Phi & .282 & .074 \\
& Cramer's V & .282 & .074 \\
& N of Valid Cases & 107 & \\
\hline
\end{tabular}

Table 91 shows the answers to survey question 52 by providing descriptive statistics, frequencies, and percentages. No association (Cramer's $V=.081)$ (Table 92) was found between the type of school (public/private) and survey question 52: Adjunct faculty are expected to be involved in governance issues.

Table 91

\section{Crosstab}

\begin{tabular}{|c|c|c|c|c|c|}
\hline \multirow[t]{2}{*}{ Q. 52} & \multicolumn{2}{|c|}{$\begin{array}{l}\text { Adjunct faculty are expected } \\
\text { to be involved in governance } \\
\text { issues }\end{array}$} & \multicolumn{3}{|c|}{ C9 =Public/Private Institutions } \\
\hline & & & Public & Private & Total \\
\hline & \multirow[t]{2}{*}{ Strongly disagree } & Count & 25 & 18 & 43 \\
\hline & & $\%$ within $C 9$ & $41.7 \%$ & $37.5 \%$ & $39.8 \%$ \\
\hline & \multirow[t]{2}{*}{ Disagree } & Count & 27 & 25 & 52 \\
\hline & & $\%$ within C9 & $45.0 \%$ & $52.1 \%$ & $48.1 \%$ \\
\hline & \multirow[t]{2}{*}{ Not sure } & Count & 4 & 3 & 7 \\
\hline & & $\%$ within $\mathrm{C} 9$ & $6.7 \%$ & $6.3 \%$ & $6.5 \%$ \\
\hline & \multirow[t]{2}{*}{ Agree } & Count & 4 & 2 & 6 \\
\hline & & $\%$ within C9 & $6.7 \%$ & $4.2 \%$ & $5.6 \%$ \\
\hline & \multirow[t]{2}{*}{ Total } & Count & 60 & 48 & 108 \\
\hline & & $\%$ within $\mathrm{C} 9$ & $100.0 \%$ & $100.0 \%$ & $100.0 \%$ \\
\hline
\end{tabular}


Table 92

Symmetric Measures

\begin{tabular}{|ll|r|r|}
\hline & & \multicolumn{1}{|c|}{ Value } & Approx. Sig. \\
\hline Nominal by Nominal & Phi & .081 & .873 \\
& Cramer's V & .081 & .873 \\
& N of Valid Cases & 108 & \\
\hline
\end{tabular}

Table 93 shows the answers to survey question 53 by providing descriptive statistics, frequencies, and percentages. A moderate association (Cramer's $\mathrm{V}=.236$ ) (Table 94) was found between the type of school (public/private) and survey question 53: Adjunct faculty are expected to serve on college and departmental committees. While a moderate association between the type of school and concerns about whether adjunct faculty members are expected to serve on college and departmental committees, this association was not significant. 
Table 93

\section{Crosstab}

\begin{tabular}{|c|c|c|c|c|c|}
\hline \multirow[t]{2}{*}{ Q. 53} & \multirow{2}{*}{\multicolumn{2}{|c|}{$\begin{array}{l}\text { Adjunct faculty are expected } \\
\text { to serve on college and } \\
\text { departmental committees }\end{array}$}} & \multicolumn{3}{|c|}{ C9 =Public/Private Institutions } \\
\hline & & & Public & Private & Total \\
\hline & \multirow[t]{2}{*}{ Strongly disagree } & Count & 28 & 18 & 46 \\
\hline & & $\%$ within C9 & $46.7 \%$ & $37.5 \%$ & $42.6 \%$ \\
\hline & \multirow[t]{2}{*}{ Disagree } & Count & 29 & 25 & 54 \\
\hline & & $\%$ within C9 & $48.3 \%$ & $52.1 \%$ & $50.0 \%$ \\
\hline & \multirow[t]{2}{*}{ Not sure } & Count & 1 & 4 & 5 \\
\hline & & $\%$ within C9 & $1.7 \%$ & $8.3 \%$ & $4.6 \%$ \\
\hline & \multirow[t]{2}{*}{ Agree } & Count & 2 & 0 & 2 \\
\hline & & $\%$ within $\mathrm{C} 9$ & $3.3 \%$ & $.0 \%$ & $1.9 \%$ \\
\hline & \multirow[t]{2}{*}{ Strongly agree } & Count & 0 & 1 & 1 \\
\hline & & $\%$ within C9 & $.0 \%$ & $2.1 \%$ & $.9 \%$ \\
\hline & \multirow[t]{2}{*}{ Total } & Count & 60 & 48 & 108 \\
\hline & & $\%$ within $\mathrm{C} 9$ & $100.0 \%$ & $100.0 \%$ & $100.0 \%$ \\
\hline
\end{tabular}

Table 94

Symmetric Measures

\begin{tabular}{|ll|r|r|}
\hline & & \multicolumn{1}{|c|}{ Value } & Approx. Sig. \\
\hline Nominal by Nominal & Phi & .236 & .198 \\
& Cramer's V & .236 & .198 \\
& N of Valid Cases & 108 & \\
\hline
\end{tabular}

Table 95 shows the answers to survey question 54 by providing descriptive statistics, frequencies, and percentages. A small association (Cramer's V $=.150$ ) (Table 96) was found 
between the type of school (public/private) and survey question 54: Adjunct faculty are expected to serve on student committees. This small association was not significant.

Table 95

Crosstab

\begin{tabular}{|c|c|c|c|c|c|}
\hline \multirow[t]{2}{*}{ Q. 54} & \multicolumn{2}{|c|}{$\begin{array}{l}\text { Adjunct faculty are expected } \\
\text { to serve on student } \\
\text { committees }\end{array}$} & \multicolumn{3}{|c|}{ C9 =Public/Private Institutions } \\
\hline & & & \multirow{3}{*}{$\begin{array}{r}\text { Public } \\
26 \\
43.3 \%\end{array}$} & \multirow{3}{*}{$\begin{array}{r}\text { Private } \\
19 \\
39.6 \%\end{array}$} & \multirow{2}{*}{ Total } \\
\hline & Strongly disagree & Count & & & \\
\hline & & $\%$ within $\mathrm{C} 9$ & & & $41.7 \%$ \\
\hline & Disagree & Count & 28 & 23 & 51 \\
\hline & & $\%$ within $\mathrm{C} 9$ & $46.7 \%$ & $47.9 \%$ & $47.2 \%$ \\
\hline & Not sure & Count & 3 & 4 & 7 \\
\hline & & $\%$ within C9 & $5.0 \%$ & $8.3 \%$ & $6.5 \%$ \\
\hline & Agree & Count & 3 & 1 & 4 \\
\hline & & $\%$ within C9 & $5.0 \%$ & $2.1 \%$ & $3.7 \%$ \\
\hline & Strongly agree & Count & 0 & 1 & 1 \\
\hline & & $\%$ within $\mathrm{C} 9$ & $.0 \%$ & $2.1 \%$ & $.9 \%$ \\
\hline & Total & Count & 60 & 48 & 108 \\
\hline & & $\%$ within C9 & $100.0 \%$ & $100.0 \%$ & $100.0 \%$ \\
\hline
\end{tabular}

Table 96

Symmetric Measures

\begin{tabular}{|ll|r|r|}
\hline & & \multicolumn{1}{|c|}{ Value } & Approx. Sig. \\
\hline Nominal by Nominal & Phi & .150 & .659 \\
& Cramer's V & .150 & .659 \\
& N of Valid Cases & 108 & \\
\hline
\end{tabular}

Table 97 shows the answers to survey question 55 by providing descriptive statistics, frequencies, and percentages. A small association (Cramer's $V=.150$ ) (Table 98) was found 
between the type of school (public/private) and survey question 55: Adjunct faculty members fully understand the expectations of satisfactory performance. This small association was not significant.

Table 97

\section{Crosstab}

\begin{tabular}{|c|c|c|c|c|c|}
\hline \multirow[t]{2}{*}{ Q. 55} & \multirow{2}{*}{\multicolumn{2}{|c|}{$\begin{array}{l}\text { Adjunct faculty members } \\
\text { fully understand the } \\
\text { expectations of satisfactory } \\
\text { performance }\end{array}$}} & \multicolumn{3}{|c|}{ C9 =Public/Private Institutions } \\
\hline & & & Public & Private & Total \\
\hline & \multirow[t]{2}{*}{ Strongly disagree } & Count & 0 & 1 & \\
\hline & & $\%$ within C9 & $.0 \%$ & $2.1 \%$ & $.9 \%$ \\
\hline & \multirow[t]{2}{*}{ Disagree } & Count & 3 & 2 & 5 \\
\hline & & $\%$ within $\mathrm{C} 9$ & $5.0 \%$ & $4.2 \%$ & $4.6 \%$ \\
\hline & \multirow[t]{2}{*}{ Not sure } & Count & 12 & 6 & 18 \\
\hline & & $\%$ within C9 & $20.0 \%$ & $12.5 \%$ & $16.7 \%$ \\
\hline & \multirow[t]{2}{*}{ Agree } & Count & 37 & 31 & 68 \\
\hline & & $\%$ within $\mathrm{C} 9$ & $61.7 \%$ & $64.6 \%$ & $63.0 \%$ \\
\hline & \multirow[t]{2}{*}{ Strongly agree } & Count & 8 & 8 & 16 \\
\hline & & $\%$ within C9 & $13.3 \%$ & $16.7 \%$ & $14.8 \%$ \\
\hline & \multirow[t]{2}{*}{ Total } & Count & 60 & 48 & 108 \\
\hline & & $\%$ within C9 & $100.0 \%$ & $100.0 \%$ & $100.0 \%$ \\
\hline
\end{tabular}

Table 98

Symmetric Measures

\begin{tabular}{|ll|l|l|}
\hline & & Value & Approx. Sig. \\
\hline Nominal by Nominal & Phi & .150 & .658 \\
& Cramer's V & .150 & .658 \\
& N of Valid Cases & 108 & \\
\hline
\end{tabular}


Table 99 shows the answers to survey question 56 by providing descriptive statistics, frequencies, and percentages. A moderate association (Cramer's $\mathrm{V}=.211)$ (Table 100) was found between the type of school (public/private) and survey question 56: Adjunct faculty members understand their role in contributing to the overall curriculum. While there was a moderate association between the type of school and concerns about whether adjunct faculty members understand their role in contributing to the overall curriculum, this association was not significant.

Table 99

Crosstab

\begin{tabular}{|c|c|c|c|c|c|}
\hline \multirow[t]{2}{*}{ Q. 56} & \multicolumn{2}{|c|}{$\begin{array}{l}\text { Adjunct faculty members } \\
\text { understand their role in } \\
\text { contributing to the overall } \\
\text { curriculum }\end{array}$} & \multicolumn{3}{|c|}{ C9 =Public/Private Institutions } \\
\hline & & & Public & Private & Total \\
\hline & \multirow[t]{2}{*}{ Strongly disagree } & Count & 1 & 0 & 1 \\
\hline & & $\%$ within $\mathrm{C} 9$ & $1.7 \%$ & $.0 \%$ & $.9 \%$ \\
\hline & \multirow[t]{2}{*}{ Disagree } & Count & 7 & 2 & 9 \\
\hline & & $\%$ within $\mathrm{C} 9$ & $11.7 \%$ & $4.2 \%$ & $8.3 \%$ \\
\hline & \multirow[t]{2}{*}{ Not sure } & Count & 10 & 11 & 21 \\
\hline & & $\%$ within C9 & $16.7 \%$ & $22.9 \%$ & $19.4 \%$ \\
\hline & \multirow[t]{2}{*}{ Agree } & Count & 37 & 27 & 64 \\
\hline & & $\%$ within $\mathrm{C} 9$ & $61.7 \%$ & $56.3 \%$ & $59.3 \%$ \\
\hline & \multirow[t]{2}{*}{ Strongly agree } & Count & 5 & 8 & 13 \\
\hline & & $\%$ within C9 & $8.3 \%$ & $16.7 \%$ & $12.0 \%$ \\
\hline & \multirow[t]{2}{*}{ Total } & Count & 60 & 48 & 108 \\
\hline & & $\%$ within C9 & $100.0 \%$ & $100.0 \%$ & $100.0 \%$ \\
\hline
\end{tabular}


Table 100

Symmetric Measures

\begin{tabular}{|ll|r|r|}
\hline & & \multicolumn{1}{|c|}{ Value } & Approx. Sig. \\
\hline Nominal by Nominal & Phi & .211 & .308 \\
& Cramer's V & .211 & .308 \\
& N of Valid Cases & 108 & \\
\hline
\end{tabular}

After descriptive statistics had been obtained for each survey item, an individual department chair's scores were summed across all survey items in a given area. For research question four, scores for survey items 46 through 56 were combined. The resulting composite scores were then averaged separately for chairs from private institutions and chairs from public institutions. These mean scores (Table 101) (public vs. private) were then compared for research question four using an ANOVA.

Table 101

Descriptives: Research Question by Public/Private Institutions

\begin{tabular}{|c|c|c|c|c|c|c|c|c|c|}
\hline \multirow[t]{2}{*}{ Research Question Four } & & \multirow[b]{2}{*}{$\mathrm{N}$} & \multirow[b]{2}{*}{ Mean } & \multirow{2}{*}{$\begin{array}{c}\text { Std. } \\
\text { Deviatio } \\
\text { n }\end{array}$} & \multirow[b]{2}{*}{ Std. Error } & \multicolumn{2}{|c|}{$\begin{array}{l}\text { 95\% Confidence Interval } \\
\text { for Mean }\end{array}$} & \multirow[b]{2}{*}{ Minimum } & \multirow[b]{2}{*}{ Maximum } \\
\hline & & & & & & $\begin{array}{l}\text { Lower } \\
\text { Bound }\end{array}$ & Upper Bound & & \\
\hline \multirow{3}{*}{$\begin{array}{l}\text { According to department } \\
\text { chairs, to what extent are } \\
\text { performance expectations } \\
\text { explained to adjunct } \\
\text { faculty? }\end{array}$} & Public & 60 & 2.8660 & .31631 & .04084 & 2.7843 & 2.9477 & 2.00 & 3.45 \\
\hline & Private & 48 & 2.9591 & .44529 & .06427 & 2.8298 & 3.0884 & 1.82 & 4.00 \\
\hline & Total & 108 & 2.9074 & .38003 & .03657 & 2.8349 & 2.9799 & 1.82 & 4.00 \\
\hline
\end{tabular}

Conducting a One-Way ANOVA, there was no significant difference (Table 102)

between chairs from public and those from private institutions on their composite scores in the area of performance expectations being explained to adjunct faculty. 
Table 102

ANOVA: Research Question by Public/Private Institutions

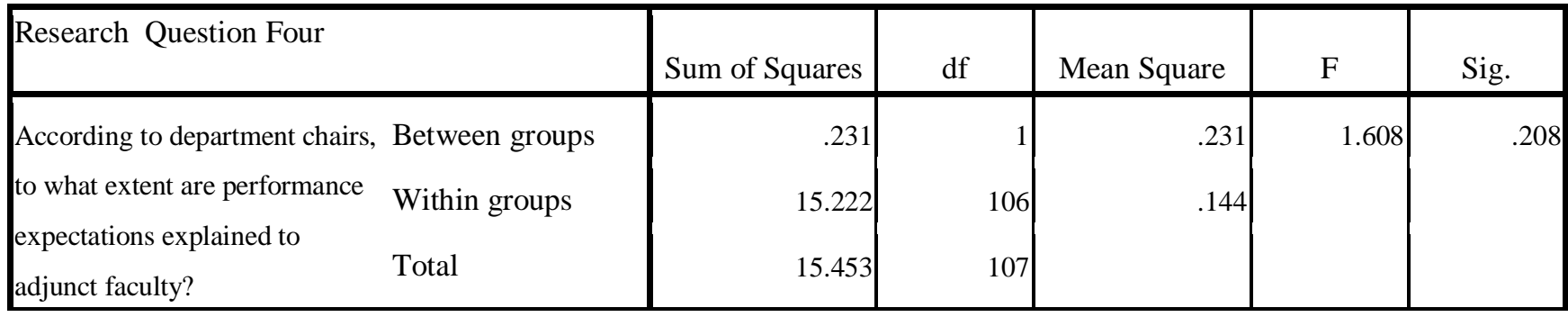

\section{Research Question Five}

The fifth research question asked: According to department chairs, to what extent are adjunct faculty satisfied with employment conditions in the department? This research question was answered by analyzing responses to survey questions 57 through 67 conducting a crosstab analysis. Table 103 shows the answers to survey question 57 by providing descriptive statistics, frequencies, and percentages. A small association (Cramer's $V=.181$ ) (Table 104) was found between the type of school (public/private) and survey question 57: Adjunct faculty are satisfied with their part-time status. This small association was not significant. 
Table 103

\section{Crosstab}

\begin{tabular}{|c|c|c|c|c|c|}
\hline \multirow[t]{2}{*}{ Q. 57} & \multicolumn{2}{|c|}{$\begin{array}{l}\text { Adjunct faculty are satisfied } \\
\text { with their part-time status }\end{array}$} & \multicolumn{3}{|c|}{ C9 =Public/Private Institutions } \\
\hline & & & Public & Private & Total \\
\hline & \multirow[t]{2}{*}{ Strongly disagree } & Count & 4 & 1 & 5 \\
\hline & & $\%$ within $\mathrm{C} 9$ & $6.7 \%$ & $2.2 \%$ & $4.7 \%$ \\
\hline & \multirow[t]{2}{*}{ Disagree } & Count & 11 & 11 & 22 \\
\hline & & $\%$ within C9 & $18.3 \%$ & $23.9 \%$ & $20.8 \%$ \\
\hline & \multirow[t]{2}{*}{ Not sure } & Count & 22 & 22 & 44 \\
\hline & & $\%$ within $\mathrm{C} 9$ & $36.7 \%$ & $47.8 \%$ & $41.5 \%$ \\
\hline & \multirow[t]{2}{*}{ Agree } & Count & 21 & 11 & 32 \\
\hline & & $\%$ within $\mathrm{C} 9$ & $35.0 \%$ & $23.9 \%$ & $30.2 \%$ \\
\hline & \multirow[t]{2}{*}{ Strongly agree } & Count & 2 & 1 & 3 \\
\hline & & $\%$ within C9 & $3.3 \%$ & $2.2 \%$ & $2.8 \%$ \\
\hline & \multirow[t]{2}{*}{ Total } & Count & 60 & 46 & 106 \\
\hline & & $\%$ within C9 & $100.0 \%$ & $100.0 \%$ & $100.0 \%$ \\
\hline
\end{tabular}

Table 104

Symmetric Measures

\begin{tabular}{|ll|r|r|}
\hline & & \multicolumn{1}{|c|}{ Value } & Approx. Sig. \\
\hline Nominal by Nominal & Phi & .181 & .482 \\
& Cramer's V & .181 & .482 \\
& $\mathrm{~N}$ of Valid Cases & 106 & \\
\hline
\end{tabular}

Table 105 shows the answers to survey question 58 by providing descriptive statistics, frequencies, and percentages. A small association (Cramer's $V=.118$ ) (Table 106) was found between the type of school (public/private) and survey question 58: Adjunct faculty are more 
satisfied as a contractual employee rather than part-time employee status. This small association was not significant.

Table 105

Crosstab

\begin{tabular}{|ll|r|r|r|}
\hline Q. 58 & \multicolumn{2}{|c|}{$\begin{array}{l}\text { Adjunct faculty are more } \\
\text { satisfied as a contractual } \\
\text { employee rather than part- } \\
\text { time employee status }\end{array}$} & \multicolumn{2}{|c|}{ C9 =Public/Private Institutions } \\
\cline { 2 - 5 } & Public & Private & \multicolumn{1}{|c|}{ Total } \\
\hline Strongly disagree & Count & 3 & 1 & 4 \\
\hline Disagree & $\%$ within C9 & $5.0 \%$ & $2.2 \%$ & $3.8 \%$ \\
\hline Not sure & Count & 7 & 3 & 10 \\
& $\%$ within C9 & $11.7 \%$ & $6.5 \%$ & $9.4 \%$ \\
\hline Agree & Count & 37 & 31 & 68 \\
& $\%$ within C9 & $61.7 \%$ & $67.4 \%$ & $64.2 \%$ \\
\hline Total & Count & 13 & 11 & 24 \\
& $\%$ within C9 & $21.7 \%$ & $23.9 \%$ & $22.6 \%$ \\
\hline & Count & 60 & 46 & 106 \\
& $\%$ within C9 & $100.0 \%$ & $100.0 \%$ & $100.0 \%$ \\
\hline
\end{tabular}

Table 106

Symmetric Measures

\begin{tabular}{|ll|r|r|}
\hline & & \multicolumn{1}{|c|}{ Value } & Approx. Sig. \\
\hline Nominal by Nominal & Phi & .118 & .689 \\
& Cramer's V & .118 & .689 \\
& N of Valid Cases & 106 & \\
\hline
\end{tabular}

Table 107 shows the answers to survey question 59 by providing descriptive statistics, frequencies, and percentages. A small association (Cramer's V $=.131$ ) (Table 108) was found 
between the type of school (public/private) and survey question 59: Adjunct faculty are satisfied with their salaries. This small association was not significant.

Table 107

Crosstab

\begin{tabular}{|c|c|c|c|c|c|}
\hline \multirow[t]{2}{*}{ Q. 59} & \multicolumn{2}{|c|}{$\begin{array}{l}\text { Adjunct faculty are satisfied } \\
\text { with their salaries }\end{array}$} & \multicolumn{3}{|c|}{ C9 =Public/Private Institutions } \\
\hline & & & Public & Private & Total \\
\hline & \multirow[t]{2}{*}{ Strongly disagree } & Count & 12 & 8 & 20 \\
\hline & & $\%$ within C9 & $20.0 \%$ & $17.4 \%$ & $18.9 \%$ \\
\hline & \multirow[t]{2}{*}{ Disagree } & Count & 29 & 28 & 57 \\
\hline & & $\%$ within C9 & $48.3 \%$ & $60.9 \%$ & $53.8 \%$ \\
\hline & \multirow[t]{2}{*}{ Not sure } & Count & 12 & 6 & 18 \\
\hline & & $\%$ within C9 & $20.0 \%$ & $13.0 \%$ & $17.0 \%$ \\
\hline & \multirow[t]{2}{*}{ Agree } & Count & 7 & 4 & 11 \\
\hline & & $\%$ within C9 & $11.7 \%$ & $8.7 \%$ & $10.4 \%$ \\
\hline & \multirow[t]{2}{*}{ Total } & Count & 60 & 46 & 106 \\
\hline & & $\%$ within $\mathrm{C} 9$ & $100.0 \%$ & $100.0 \%$ & $100.0 \%$ \\
\hline
\end{tabular}

Table 108

Symmetric Measures

\begin{tabular}{|ll|r|r|}
\hline & & \multicolumn{1}{|c|}{ Value } & Approx. Sig. \\
\hline Nominal by Nominal & Phi & .131 & .611 \\
& Cramer's V & .131 & .611 \\
& $\mathrm{~N}$ of Valid Cases & 106 & \\
\hline
\end{tabular}

Table 109 shows the answers to survey question 60 by providing descriptive statistics, frequencies, and percentages. A small association (Cramer's V = .103) (Table 110) was found between the type of school (public/private) and survey question 60: Adjunct faculty are eligible for salary increases from one year to the next. This small association was not significant. 
Table 109

\section{Crosstab}

\begin{tabular}{|c|c|c|c|c|c|}
\hline \multirow[t]{2}{*}{ Q. 60} & \multicolumn{2}{|c|}{$\begin{array}{l}\text { Adjunct faculty are eligible } \\
\text { for salary increases from one } \\
\text { year to the next }\end{array}$} & \multicolumn{3}{|c|}{ C9 =Public/Private Institutions } \\
\hline & & & Public & Private & Total \\
\hline & \multirow[t]{2}{*}{ Strongly disagree } & Count & 10 & 8 & 18 \\
\hline & & $\%$ within C9 & $16.9 \%$ & $17.8 \%$ & $17.3 \%$ \\
\hline & \multirow[t]{2}{*}{ Disagree } & Count & 31 & 20 & 51 \\
\hline & & $\%$ within C9 & $52.5 \%$ & $44.4 \%$ & $49.0 \%$ \\
\hline & \multirow[t]{2}{*}{ Not sure } & Count & 7 & 5 & 12 \\
\hline & & $\%$ within C9 & $11.9 \%$ & $11.1 \%$ & $11.5 \%$ \\
\hline & \multirow[t]{2}{*}{ Agree } & Count & 11 & 12 & 23 \\
\hline & & $\%$ within C9 & $18.6 \%$ & $26.7 \%$ & $22.1 \%$ \\
\hline & \multirow[t]{2}{*}{ Total } & Count & 59 & 45 & 104 \\
\hline & & $\%$ within $\mathrm{C} 9$ & $100.0 \%$ & $100.0 \%$ & $100.0 \%$ \\
\hline
\end{tabular}

Table 110

Symmetric Measures

\begin{tabular}{|ll|r|r|}
\hline & & \multicolumn{1}{|c|}{ Value } & Approx. Sig. \\
\hline Nominal by Nominal & Phi & .103 & .775 \\
& Cramer's V & .103 & .775 \\
& N of Valid Cases & 104 & \\
\hline
\end{tabular}

Table 111 shows the answers to survey question 61 by providing descriptive statistics, frequencies, and percentages. A small association (Cramer's $V=.182$ ) (Table 112) was found between the type of school (public/private) and survey question 61: Adjunct faculty are satisfied with the conditions for reappointment. This small association was not significant. 
Table 111

\section{Crosstab}

\begin{tabular}{|c|c|c|c|c|c|}
\hline \multirow[t]{2}{*}{ Q. 61} & \multicolumn{2}{|c|}{$\begin{array}{l}\text { Adjunct faculty are satisfied } \\
\text { with the conditions for } \\
\text { reappointment }\end{array}$} & \multicolumn{3}{|c|}{ C9 =Public/Private Institutions } \\
\hline & & & Public & Private & Total \\
\hline & \multirow[t]{2}{*}{ Strongly disagree } & Count & 2 & 1 & 3 \\
\hline & & $\%$ within C9 & $3.4 \%$ & $2.2 \%$ & $2.9 \%$ \\
\hline & \multirow[t]{2}{*}{ Disagree } & Count & 7 & 7 & 14 \\
\hline & & $\%$ within C9 & $11.9 \%$ & $15.2 \%$ & $13.3 \%$ \\
\hline & \multirow[t]{2}{*}{ Not sure } & Count & 23 & 14 & 37 \\
\hline & & $\%$ within C9 & $39.0 \%$ & $30.4 \%$ & $35.2 \%$ \\
\hline & \multirow[t]{2}{*}{ Agree } & Count & 27 & 22 & 49 \\
\hline & & $\%$ within C9 & $45.8 \%$ & $47.8 \%$ & $46.7 \%$ \\
\hline & \multirow[t]{2}{*}{ Strongly agree } & Count & 0 & 2 & 2 \\
\hline & & $\%$ within C9 & $.0 \%$ & $4.3 \%$ & $1.9 \%$ \\
\hline & \multirow[t]{2}{*}{ Total } & Count & 59 & 46 & 105 \\
\hline & & $\%$ within C9 & $100.0 \%$ & $100.0 \%$ & $100.0 \%$ \\
\hline
\end{tabular}

Table 112

Symmetric Measures

\begin{tabular}{|ll|r|r|}
\hline & & \multicolumn{1}{|c|}{ Value } & Approx. Sig. \\
\hline Nominal by Nominal & Phi & .182 & .481 \\
& Cramer's V & .182 & .481 \\
& $\mathrm{~N}$ of Valid Cases & 105 & \\
\hline
\end{tabular}

Table 113 shows the answers to survey question 62 by providing descriptive statistics, frequencies, and percentages. A small association (Cramer's $V=.185$ ) (Table 114) was found between the type of school (public/private) and survey question 62: Adjunct faculty have opportunities for promotion. This small association was not significant. 
Table 113

\section{Crosstab}

\begin{tabular}{|c|c|c|c|c|c|}
\hline \multirow[t]{2}{*}{ Q.62 } & \multicolumn{2}{|c|}{$\begin{array}{l}\text { Adjunct faculty have } \\
\text { opportunities for promotion }\end{array}$} & \multicolumn{3}{|c|}{ C9 =Public/Private Institutions } \\
\hline & & & \multirow{3}{*}{$\begin{array}{r}\text { Public } \\
17 \\
28.3 \%\end{array}$} & \multirow{3}{*}{$\begin{array}{r}\text { Private } \\
11 \\
23.9 \% \\
\end{array}$} & \multirow{2}{*}{$\frac{\text { Total }}{28}$} \\
\hline & Strongly disagree & Count & & & \\
\hline & & $\%$ within C9 & & & $26.4 \%$ \\
\hline & Disagree & Count & 31 & 21 & 52 \\
\hline & & $\%$ within $\mathrm{C} 9$ & $51.7 \%$ & $45.7 \%$ & $49.1 \%$ \\
\hline & Not sure & Count & 3 & 4 & 7 \\
\hline & & $\%$ within C9 & $5.0 \%$ & $8.7 \%$ & $6.6 \%$ \\
\hline & Agree & Count & 9 & 8 & 17 \\
\hline & & $\%$ within C9 & $15.0 \%$ & $17.4 \%$ & $16.0 \%$ \\
\hline & Strongly agree & Count & 0 & 2 & 2 \\
\hline & & $\%$ within C9 & $.0 \%$ & $4.3 \%$ & $1.9 \%$ \\
\hline & Total & Count & 60 & 46 & 106 \\
\hline & & $\%$ within C9 & $100.0 \%$ & $100.0 \%$ & $100.0 \%$ \\
\hline
\end{tabular}

Table 114

Symmetric Measures

\begin{tabular}{|ll|r|r|}
\hline & & \multicolumn{1}{|c|}{ Value } & Approx. Sig. \\
\hline Nominal by Nominal & Phi & .185 & .459 \\
& Cramer's V & .185 & .459 \\
& $\mathrm{~N}$ of Valid Cases & 106 & \\
\hline
\end{tabular}

Table 115 shows the answers to survey question 63 by providing descriptive statistics, frequencies, and percentages. A small association (Cramer's $V=.144)$ (Table 116) was found between the type of school (public/private) and survey question 63: Adjunct faculty are satisfied with secretarial support they receive. This small association was not significant. 
Table 115

\section{Crosstab}

\begin{tabular}{|c|c|c|c|c|c|}
\hline \multirow[t]{2}{*}{ Q. 63} & \multicolumn{2}{|c|}{$\begin{array}{l}\text { Adjunct faculty are satisfied } \\
\text { with secretarial support they } \\
\text { receive }\end{array}$} & \multicolumn{3}{|c|}{ C9 =Public/Private Institutions } \\
\hline & & & Public & Private & Total \\
\hline & \multirow[t]{2}{*}{ Strongly disagree } & Count & 2 & 4 & 6 \\
\hline & & $\%$ within $\mathrm{C} 9$ & $3.3 \%$ & $8.7 \%$ & $5.7 \%$ \\
\hline & \multirow[t]{2}{*}{ Disagree } & Count & 2 & 3 & 5 \\
\hline & & $\%$ within $\mathrm{C} 9$ & $3.3 \%$ & $6.5 \%$ & $4.7 \%$ \\
\hline & \multirow[t]{2}{*}{ Not sure } & Count & 22 & 16 & 38 \\
\hline & & $\%$ within $\mathrm{C} 9$ & $36.7 \%$ & $34.8 \%$ & $35.8 \%$ \\
\hline & \multirow[t]{2}{*}{ Agree } & Count & 29 & 19 & 48 \\
\hline & & $\%$ within C9 & $48.3 \%$ & $41.3 \%$ & $45.3 \%$ \\
\hline & \multirow[t]{2}{*}{ Strongly agree } & Count & 5 & 4 & 9 \\
\hline & & $\%$ within C9 & $8.3 \%$ & $8.7 \%$ & $8.5 \%$ \\
\hline & \multirow[t]{2}{*}{ Total } & Count & 60 & 46 & 106 \\
\hline & & $\%$ within C9 & $100.0 \%$ & $100.0 \%$ & $100.0 \%$ \\
\hline
\end{tabular}

Table 116

Symmetric Measures

\begin{tabular}{|ll|r|r|}
\hline & & \multicolumn{1}{|c|}{ Value } & Approx. Sig. \\
\hline Nominal by Nominal & Phi & .144 & .699 \\
& Cramer's V & .144 & .699 \\
& $\mathrm{~N}$ of Valid Cases & 106 & \\
\hline
\end{tabular}

Table 117 shows the answers to survey question 64 by providing descriptive statistics, frequencies, and percentages. A small association (Cramer's V = .181) (Table 118) was found between the type of school (public/private) and survey question 64: Adjunct faculty are satisfied 
with office space and equipment made available to them. This small association was not significant.

Table 117

Crosstab

\begin{tabular}{|c|c|c|c|c|c|}
\hline \multirow[t]{2}{*}{ Q. 64} & \multicolumn{2}{|c|}{$\begin{array}{l}\text { Adjunct faculty are satisfied } \\
\text { with office space and } \\
\text { equipment made available to } \\
\text { them }\end{array}$} & \multicolumn{3}{|c|}{ C9 $=$ Public/Private Institutions } \\
\hline & & & Public & Private & Total \\
\hline & \multirow[t]{2}{*}{ Strongly disagree } & Count & 2 & 3 & 5 \\
\hline & & $\%$ within $\mathrm{C} 9$ & $3.3 \%$ & $6.5 \%$ & $4.7 \%$ \\
\hline & \multirow[t]{2}{*}{ Disagree } & Count & 6 & 8 & 14 \\
\hline & & $\%$ within C9 & $10.0 \%$ & $17.4 \%$ & $13.2 \%$ \\
\hline & \multirow[t]{2}{*}{ Not sure } & Count & 14 & 13 & 27 \\
\hline & & $\%$ within C9 & $23.3 \%$ & $28.3 \%$ & $25.5 \%$ \\
\hline & \multirow[t]{2}{*}{ Agree } & Count & 35 & 19 & 54 \\
\hline & & $\%$ within $\mathrm{C} 9$ & $58.3 \%$ & $41.3 \%$ & $50.9 \%$ \\
\hline & \multirow[t]{2}{*}{ Strongly agree } & Count & 3 & 3 & 6 \\
\hline & & $\%$ within C9 & $5.0 \%$ & $6.5 \%$ & $5.7 \%$ \\
\hline & \multirow[t]{2}{*}{ Total } & Count & 60 & 46 & 106 \\
\hline & & $\%$ within C9 & $100.0 \%$ & $100.0 \%$ & $100.0 \%$ \\
\hline
\end{tabular}

Table 118

Symmetric Measures

\begin{tabular}{|ll|r|r|}
\hline & & \multicolumn{1}{|c|}{ Value } & Approx. Sig. \\
\hline Nominal by Nominal & Phi & .181 & .482 \\
& Cramer's V & .181 & .482 \\
& N of Valid Cases & 106 & \\
\hline
\end{tabular}


Table 119 shows the answers to survey question 65 by providing descriptive statistics, frequencies, and percentages. A small association (Cramer's $V=.151$ ) (Table 120) was found between the type of school (public/private) and survey question 65: Adjunct faculty are included in departmental social events. This small association was not significant.

Table 119

\section{Crosstab}

\begin{tabular}{|c|c|c|c|c|c|}
\hline \multirow[t]{2}{*}{ Q. 65} & \multicolumn{2}{|c|}{$\begin{array}{l}\text { Adjunct faculty are included } \\
\text { in departmental social events }\end{array}$} & \multicolumn{3}{|c|}{ C9 =Public/Private Institutions } \\
\hline & & & Public & Private & Total \\
\hline & \multirow[t]{2}{*}{ Strongly disagree } & Count & 0 & 1 & 1 \\
\hline & & $\%$ within $\mathrm{C} 9$ & $.0 \%$ & $2.2 \%$ & $.9 \%$ \\
\hline & \multirow[t]{2}{*}{ Disagree } & Count & 10 & 6 & 16 \\
\hline & & $\%$ within C9 & $16.7 \%$ & $13.0 \%$ & $15.1 \%$ \\
\hline & \multirow[t]{2}{*}{ Not sure } & Count & 6 & 7 & 13 \\
\hline & & $\%$ within C9 & $10.0 \%$ & $15.2 \%$ & $12.3 \%$ \\
\hline & \multirow[t]{2}{*}{ Agree } & Count & 30 & 20 & 50 \\
\hline & & $\%$ within C9 & $50.0 \%$ & $43.5 \%$ & $47.2 \%$ \\
\hline & \multirow[t]{2}{*}{ Strongly agree } & Count & 14 & 12 & 26 \\
\hline & & $\%$ within $\mathrm{C} 9$ & $23.3 \%$ & $26.1 \%$ & $24.5 \%$ \\
\hline & \multirow[t]{2}{*}{ Total } & Count & 60 & 46 & 106 \\
\hline & & $\%$ within C9 & $100.0 \%$ & $100.0 \%$ & $100.0 \%$ \\
\hline
\end{tabular}

Table 120

Symmetric Measures

\begin{tabular}{|ll|r|r|}
\hline & & \multicolumn{1}{|c|}{ Value } & Approx. Sig. \\
\hline Nominal by Nominal & Phi & .151 & .658 \\
& Cramer's V & .151 & .658 \\
& N of Valid Cases & 106 & \\
\hline
\end{tabular}


Table 121 shows the answers to survey question 66 by providing descriptive statistics, frequencies, and percentages. A moderate association (Cramer's $\mathrm{V}=.236)$ (Table 122) was found between the type of school (public/private) and survey question 66: Adjunct faculty are satisfied with the number of credit hours they can teach at our college. While there was a moderate association between the type of school and concerns about whether adjunct faculty are satisfied with the number of credit hours they can teach at our college, this association was not significant.

Table 121

Crosstab

\begin{tabular}{|c|c|c|c|c|c|}
\hline \multirow[t]{2}{*}{ Q. 66} & \multirow{2}{*}{\multicolumn{2}{|c|}{$\begin{array}{l}\text { Adjunct faculty are satisfied } \\
\text { with the number of credit } \\
\text { hours they can teach at our } \\
\text { college }\end{array}$}} & \multicolumn{3}{|c|}{ C9 =Public/Private Institutions } \\
\hline & & & Public & Private & Total \\
\hline & \multirow[t]{2}{*}{ Strongly disagree } & Count & 1 & 2 & 3 \\
\hline & & $\%$ within $\mathrm{C} 9$ & $1.7 \%$ & $4.3 \%$ & $2.8 \%$ \\
\hline & \multirow[t]{2}{*}{ Disagree } & Count & 7 & 9 & 16 \\
\hline & & $\%$ within C9 & $11.7 \%$ & $19.6 \%$ & $15.1 \%$ \\
\hline & \multirow[t]{2}{*}{ Not sure } & Count & 29 & 15 & 44 \\
\hline & & $\%$ within C9 & $48.3 \%$ & $32.6 \%$ & $41.5 \%$ \\
\hline & \multirow[t]{2}{*}{ Agree } & Count & 23 & 18 & 41 \\
\hline & & $\%$ within C9 & $38.3 \%$ & $39.1 \%$ & $38.7 \%$ \\
\hline & \multirow[t]{2}{*}{ Strongly agree } & Count & 0 & 2 & 2 \\
\hline & & $\%$ within C9 & $.0 \%$ & $4.3 \%$ & $1.9 \%$ \\
\hline & \multirow[t]{2}{*}{ Total } & Count & 60 & 46 & 106 \\
\hline & & $\%$ within C9 & $100.0 \%$ & $100.0 \%$ & $100.0 \%$ \\
\hline
\end{tabular}


Table 122

Symmetric Measures

\begin{tabular}{|ll|r|r|}
\hline & & \multicolumn{1}{|c|}{ Value } & Approx. Sig. \\
\hline Nominal by Nominal & Phi & .236 & .207 \\
& Cramer's V & .236 & .207 \\
& N of Valid Cases & 106 & \\
\hline
\end{tabular}

Table 123 shows the answers to survey question 67 by providing descriptive statistics, frequencies, and percentages. A moderate association (Cramer's V = .216) (Table 124) was found between the type of school (public/private) and survey question 67: Adjunct faculty are hired as part-time employees rather than contractees. While there was a moderate association between the type of school and concerns about whether adjunct faculty are hired as part-time employees rather than contractees, this association was not significant. 
Table 123

\section{Crosstab}

\begin{tabular}{|c|c|c|c|c|c|}
\hline \multirow[t]{2}{*}{ Q. 67} & \multicolumn{2}{|c|}{$\begin{array}{l}\text { Adjunct faculty are hired as } \\
\text { part-time employees rather } \\
\text { than contractees }\end{array}$} & \multicolumn{3}{|c|}{ C9 =Public/Private Institutions } \\
\hline & & & Public & Private & Total \\
\hline & \multirow[t]{2}{*}{ Strongly disagree } & Count & 9 & 4 & 13 \\
\hline & & $\%$ within $\mathrm{C} 9$ & $15.3 \%$ & $8.9 \%$ & $12.5 \%$ \\
\hline & \multirow[t]{2}{*}{ Disagree } & Count & 20 & 14 & 34 \\
\hline & & $\%$ within $\mathrm{C} 9$ & $33.9 \%$ & $31.1 \%$ & $32.7 \%$ \\
\hline & \multirow[t]{2}{*}{ Not sure } & Count & 13 & 9 & 22 \\
\hline & & $\%$ within $\mathrm{C} 9$ & $22.0 \%$ & $20.0 \%$ & $21.2 \%$ \\
\hline & \multirow[t]{2}{*}{ Agree } & Count & 11 & 16 & 27 \\
\hline & & $\%$ within $\mathrm{C} 9$ & $18.6 \%$ & $35.6 \%$ & $26.0 \%$ \\
\hline & \multirow[t]{2}{*}{ Strongly agree } & Count & 6 & 2 & 8 \\
\hline & & $\%$ within C9 & $10.2 \%$ & $4.4 \%$ & $7.7 \%$ \\
\hline & \multirow[t]{2}{*}{ Total } & Count & 59 & 45 & 104 \\
\hline & & $\%$ within C9 & $100.0 \%$ & $100.0 \%$ & $100.0 \%$ \\
\hline
\end{tabular}

Table 124

Symmetric Measures

\begin{tabular}{|ll|r|r|}
\hline & & \multicolumn{1}{|c|}{ Value } & Approx. Sig. \\
\hline Nominal by Nominal & Phi & .216 & .304 \\
& Cramer's V & .216 & .304 \\
& N of Valid Cases & 104 & \\
\hline
\end{tabular}

After descriptive statistics had been obtained for each survey item, an individual department chair's scores were summed across all survey items in a given area. For research question five, scores for survey items 57 through 67 were combined. The resulting composite scores were then averaged separately for chairs from private institutions and chairs from public 
institutions. These mean scores (Table 125) (public vs. private) were then compared for research question five using an ANOVA.

Table 125

Descriptives: Research Question by Public/Private Institutions

\begin{tabular}{|c|c|c|c|c|c|c|c|c|c|}
\hline & \multirow[t]{2}{*}{ Research Question Five } & \multirow[b]{2}{*}{$\mathrm{N}$} & \multirow[b]{2}{*}{ Mean } & \multirow{2}{*}{$\begin{array}{c}\text { Std. } \\
\text { Deviatio } \\
\mathrm{n}\end{array}$} & \multirow[b]{2}{*}{ Std. Error } & \multicolumn{2}{|c|}{$\begin{array}{l}\text { 95\% Confidence Interval } \\
\text { for Mean }\end{array}$} & \multirow[b]{2}{*}{ Minimum } & \multirow[b]{2}{*}{ Maximum } \\
\hline & & & & & & $\begin{array}{l}\text { Lower } \\
\text { Bound }\end{array}$ & Upper Bound & & \\
\hline \multirow{3}{*}{$\begin{array}{l}\text { According to department } \\
\text { chairs, to what extent are } \\
\text { adjunct faculty satisfied } \\
\text { with employment } \\
\text { conditions in the } \\
\text { department? }\end{array}$} & Public & 60 & 2.9856 & .38164 & .04927 & 2.8870 & 3.0842 & 2.09 & 3.73 \\
\hline & Private & 46 & 2.9955 & .44942 & .06626 & 2.8620 & 3.1289 & 1.91 & 3.82 \\
\hline & Total & 106 & 2.9899 & .41040 & .03986 & 2.9108 & 3.0689 & 1.91 & 3.82 \\
\hline
\end{tabular}

Conducting a One-Way ANOVA, there was no significant difference (Table 126)

between chairs from public and those from private institutions on their composite scores in the area of adjunct faculty satisfaction with employment conditions in the department.

Table 126

ANOVA: Research Question by Public/Private Institutions

\begin{tabular}{|c|c|c|c|c|c|c|}
\hline Research Question Five & & Sum of Squares & df & Mean Square & $\mathrm{F}$ & Sig. \\
\hline $\begin{array}{l}\text { According to department chairs, } \\
\text { to what extent are adjunct } \\
\text { faculty satisfied with } \\
\text { employment conditions in the } \\
\text { department? }\end{array}$ & $\begin{array}{l}\text { Between groups } \\
\text { Within groups } \\
\text { Total }\end{array}$ & $\begin{array}{r}.003 \\
17.682 \\
17.685\end{array}$ & $\begin{array}{r}1 \\
104 \\
105\end{array}$ & $\begin{array}{l}.003 \\
.170\end{array}$ & .015 & .903 \\
\hline
\end{tabular}




\section{Summary}

There was a strong, significant association found between the type of school (public/private) and survey question 50: Adjunct faculty members are expected to use studentcentered effective teaching techniques).

Conducting a One-Way ANOVA, there was a significant difference between chairs from public and those from private institutions on their composite scores in the area of the extent adjunct faculty are evaluated and what evidence is required 


\section{Chapter Five:}

\section{Summary, Conclusions, and Recommendations}

Based on prior literature and the findings of this research study, this chapter provides a summary, conclusions, recommendations for practice, and recommendations for further research.

The purpose of this study was to describe the status of adjunct faculty in Maryland public and private four-year colleges and universities as perceived by the department chairs and whether there were significant differences between private versus public. In this study, the following research questions were addressed:

1. According to department chairs, to what extent is information collected on the professional commitments of their adjunct faculty? Is there a significant difference between public and private institutions in the perceptions of department chairs as to the extent information is collected on the professional commitments of their adjunct faculty?

2. According to department chairs, to what extent are adjunct faculty evaluated and what evidence is required? Is there a significant difference between public and private institutions in the perceptions of department chairs as to the extent adjunct faculty members are evaluated and what evidence is required?

3. According to department chairs, to what extent do adjunct faculty become integrated into the department? Is there a significant difference between public and private institutions in the perceptions of department chairs as to the extent adjunct faculty become integrated into the department?

4. According to department chairs, to what extent are performance expectations explained to adjunct faculty? Is there a significant difference between public and private institutions in the 
perceptions of department chairs as to the extent performance expectations are explained to adjunct faculty?

5. According to department chairs, to what extent are adjunct faculty satisfied with employment conditions in the department? Is there a significant difference between public and private institutions in the perceptions of department chairs as to the extent adjunct faculty is satisfied with employment conditions in the department?

Of the department chairs completing the survey, 71 were males $(56.8 \%)$ and 49 were females (39.2\%), with 5 omissions (4.0\%). A majority, $(n=66 ; 52.8 \%)$, had served as chair between 1-5 years, followed by 37 (29.6\%) serving 6-10 years, nine (7.2\%) serving 11-15 years, six (4.8\%) serving 16-20 years, one (.8\%) serving $21-25$ years, and finally, two (1.6\%) serving more than 25 years.

A substantial number of department chairs $(n=41 ; 32.8 \%)$, have taught more than 25 years in college and/or university, followed by 28 (22.4\%) having taught $21-25$ years. Of the remaining department chairs, $19(15.2 \%)$ have taught 16-20 years, 24 (19.2\%) have taught 11-15 years, and finally, nine (7.2\%) taught 6-10 years.

The mix of chairs from private versus public institutions was fairly even, with 65 chairs $(52 \%)$ representing public institutions and $(n=55 ; 44 \%)$ representing private institutions. Five failed to respond to this item. In terms of academic degrees, $108(86.4 \%)$ chairs completing the survey had earned the doctorate, with $11(8.8 \%)$ holding a masters degree. Six chairs did not respond to this item.

The majority of adjuncts hired were White $(n=107 ; 40 \%)$, followed by Black $(n=50$; $19 \%)$, Asians $(n=42 ; 15.8 \%)$, Hispanics $(n=36 ; 13.5 \%)$, and other $(n=30 ; 11.3 \%)$. As to who was responsible for the hiring of adjunct faculty, the majority $(n=109 ; 87.2 \%)$ of responses indicated 
that hiring decisions were originally made by the department chairs. Department tenured faculty $(n=7,5.6 \%)$ and deans $(n=5 ; 4.5 \%)$ comprised less than $10 \%$ of the decisions to hire adjunct faculty. What were the primary reasons for hiring adjunct faculty? According to the department chairs' responses, insufficient full-time faculty ranked among the highest at $30.2 \%$. Increased enrollment, expertise, teaching introduction courses, budget restraints, sabbatical and other, comprised approximately $42 \%$ of reasons for hiring adjunct faculty. Ten respondents did not answer this item.

Many department chairs $(n=38 ; 30.4 \%)$ suggested that the number of credit hours adjuncts are allowed to teach a semester should be 4-6 credit hours. Thirty-one department chairs (24.8\%), responded that 7-9 credit hours taught by adjuncts was appropriate. Thirty (24\%) department chairs responded that is it was fine if adjuncts taught more than nine credit hours a semester while only 15 department chairs $(12 \%)$ reported that the number of credit hours taught by adjuncts not exceed 1-3 credit hours per semester. Eleven omissions (8.8\%) were recorded on this item.

In determining the difficulty in hiring adjunct faculty to meet programs needs $11(8.8 \%)$ department chairs found it extremely difficult to employ qualified adjunct faculty to meet their programs needs. Fifteen department chairs (12\%) found it very difficult to employ qualified adjunct faculty to meet their programs needs. Twenty-seven $(21.6 \%)$ department chairs responded that it was difficult to employ qualified adjunct faculty to meet their programs needs. Thirty-nine (31.2\%) department chairs responded that it was somewhat difficult to employ qualified adjunct faculty and 25 (20.0\%) department chairs found it not difficult at all. Missing system data totaled $8(6.4 \%)$. 
Five different departments were represented in this study, with Liberal Arts having the highest number $(\mathrm{n}=52 ; 41.6 \%)$ and Education having the least $(\mathrm{n}=4 ; 3.2 \%)$, with $(\mathrm{n}=15 ; 12 \%)$ not providing that information.

\section{Conclusions}

Research question one asked: According to department chairs, to what extent is information collected on the professional commitments of their adjunct faculty and is there a significant difference between public and private institutions in the perceptions of department chairs as to the extent information is collected on the professional commitments of their adjunct faculty?

This research question was answered by analyzing responses to survey questions 17 through 28 conducting a crosstab analysis, providing descriptive statistics, frequencies, and percentages. While there were small to moderate associations between the type of school (public/private) and survey items in research question one, none of these associations were significant. Conducting a One-Way ANOVA, there was no significant difference between chairs from public and those from private institutions on their composite scores in the area of information collected on the professional commitments of their adjunct faculty.

In general, part-time faculty members are hired to teach specific courses for a specific time period. Department chairs typically do most of the hiring (Christensen, 2008); therefore, their focus is on what adjuncts bring to the teaching environment, not so much their role as a “professional educator.” Department chairs in this study overwhelmingly did the hiring of adjunct faculty. For example, 109 (90\%) of chairs from both public and private institutions responded they were responsible for the hiring of adjunct faculty. In addition, chairs from both 
public $15(24.4 \%)$ and private $15(30.6 \%)$ institutions responded that they were concerned about adjunct faculty commitments at other institutions.

While it is helpful and perhaps even necessary for department chairs to know something about their prospective adjuncts, but only to the extent of their expertise in a particular field. Beyond the basic information needed for hiring, department chairs do not collect significant amounts of data on part-time faculty prior to teaching.

The second research question asked: According to department chairs, to what extent are adjunct faculty evaluated and what evidence is required and is there a significant difference between public and private institutions in the perceptions of department chairs as to the extent adjunct faculty are evaluated and evidence required?

This research question was answered by analyzing responses to survey questions 29 through 38 conducting a crosstab analysis, providing descriptive statistics, frequencies, and percentages. While there were small to moderate associations between the type of school (public/private) and survey items in research question two, none of these associations were significant. Conducting a One-Way ANOVA, there was a significant difference $(p<.10)$ between chairs from public and those from private institutions on their composite scores in the area of the extent adjunct faculty are evaluated and what evidence is required. Department chairs from private institutions had a higher mean score than department chairs from public institutions when asked about the extent adjunct faculty are evaluated and the evidence required. This indicates chairs from private institutions agreed more with this statement, resulting in a higher mean score.

Also, public and private school chairs had a moderate, but not significant difference in how they answered survey question 29. For example, $49.2 \%$ of department chairs from public 
institutions and $41.7 \%$ from private institutions disagreed that adjunct faculty should be evaluated the same as full time faculty. In contrast, $28.8 \%$ of department chairs from public institutions and $27.1 \%$ from private institutions agreed that adjunct faculty should be evaluated the same as full time faculty.

Styne (1997) discussed how new instructors have more experienced instructors visit the classroom in the first and second semester of teaching. Feedback on ways to improve in the classroom is then provided to the new adjuncts. According to Styne this practice has proven to be successful and much appreciated by new adjuncts. The current study fully supports this argument. For example, when department chairs from public institutions were asked, should adjunct faculty be evaluated in the classroom by peer faculty members, $71.7 \%(n=43)$ said they agreed and $58.3 \%(\mathrm{n}=28)$ from private institutions said they agreed. In contrast, $11.7 \%(\mathrm{n}=7)$ of department chairs from public institutions and $8.3 \%(n=4)$ from private institutions said they disagreed. This study does not dispute the need for evaluation of part-time faculty, but the evaluation process may really be the issue.

As Behrendt and Parsons (1983) suggest, evaluation plays a significant role in faculty integration into an institution. The AAUP (1998) noted that adjunct faculty members are much less likely than full-time faculty to receive any type of evaluations. Institutions, however, are beginning to establish policies for formal evaluation of adjuncts (Baron-Nixon, 2007; Parsons, 1998; Styne, 1997). Part of the reason for formal policies being developed is the demand from "the customers" to know they are receiving quality instruction (Williams, 1994). Student evaluations are the most common form of evaluation in many institutions. These evaluations are usually standardized forms filled out on a periodic basis, usually once a semester, and for many part-time faculty members these evaluations are the only form of feedback they receive. 
The third research question asked: According to department chairs, to what extent do adjunct faculty become integrated into the department and is there a significant difference between public and private institutions in the perceptions of department chairs as to the extent adjunct faculty become integrated into the department?

This research question was answered by analyzing responses to survey questions 39 through 45 conducting a crosstab analysis, providing descriptive statistics, frequencies, and percentages. While there were small to moderate associations between the type of school (public/private) and survey items in research question three, none of these associations were significant. Conducting a One-Way ANOVA, there was no significant difference between chairs from public and those from private institutions on their composite scores in the area of adjunct faculty becoming integrated into the department.

The lack of integration, however, in many department programs is a critical issue because it often leads to feelings of exclusion and isolation and decreasing job satisfaction (Balch, 1999; Baron-Nixon, 2007; Finucane \& Algren, 1997; and Rifkin, 1998). Roueche et al. (1996a, 1996b) suggest that integration of part-time faculty into department programs is vital not only for the department, but also for the institution as well. Forty-two percent from public institutions and $56.3 \%$ from private institutions in this study agreed about the importance of integration into the department. Department chairs responded similarly when asked if adjunct faculty understand the program's learning outcomes - with 29 (49.2\%) from public institutions and $26(54.2 \%)$ from private institutions. However, department chairs from public $21(35.6 \%)$ and $12(25 \%)$ from private institutions were not sure if adjunct faculty understand the program's mission.

Kelly’s (1991) study suggests that most part-time faculty do not attend meetings at the departmental or institutional level or serve on committees. However, other research indicates 
many would like to be included (Baron-Nixon, 2007; Pollington, 1991). Kelly found that some part-time faculty members were invited to faculty meetings, but most of those who were invited could not attend because of scheduling conflicts. She also found that part-timers who attended division meetings felt more involved in the campus community. Consistent with Kelly’s (1991) study, chairs from public institutions $24(40 \%)$ and $20(41.7 \%)$ from private institutions in this study did not believe adjunct faculty are included in the formulation of strategies and plans that reflect the mission and educational objectives of the department and institution.

The forth research question asked: According to department chairs, to what extent are performance expectations explained to adjunct faculty and is there a significant difference between public and private institutions in the perceptions of department chairs as to the extent performance expectations are explained to adjunct faculty?

This research question was answered by analyzing responses to survey questions 46 through 56 conducting a crosstab analysis, providing descriptive statistics, frequencies, and percentages. While there were small to moderate associations between the type of school (public/private) and survey items in research question four, none of these associations were significant except survey question number 50: Adjunct faculty are expected to use studentcentered effective teaching techniques.

Research question four and survey question 50 dealt with the extent to which adjunct faculty are expected to use student-centered effective teaching methods. There was a strong, significant association found between the type of school (public/private) and survey question 50 . For example, $41(70.7 \%)$ from public institutions and $26(54.2 \%)$ from private institutions agreed that adjunct faculty are expected to use student-centered effective teaching techniques. While chairs from both public and private institutions tended to agree with this statement, chairs from 
private institutions were much more spilt in their responses. Conducting a One-Way ANOVA, there was no significant difference between chairs from public and those from private institutions on their composite scores in the area of adjunct faculty are expected to use student-centered effective teaching techniques.

Survey question 47 asked whether adjunct faculty members are expected to serve as an advisor to students. There was a moderate but not significant association in how chairs answered this survey question, with 39 (65\%) of department chairs from public institutions and 23 (47.9\%) department chairs from private institutions indicating that adjunct faculty are not expected to serve as an advisor to students.

As for advising responsibilities, chairs responded that in general, adjuncts teaching one course are not expected to advise students. However, those part-time faculty members teaching more than one course are expected to participate in students advising. Pisani and Stott (1998) argue against the use of adjuncts because doing so erodes the quality of student advising. The findings in this study indicate adjunct faculty members are not expected to serve as an advisor to students. For example, chairs from public $39(65 \%)$ and chairs from private institutions 23 (47.9\%) responded that adjunct faculty members are not expected to serve as an advisor to students.

Pisani and Stott (1998) also suggest that the use of part-time faculty increases the distribution of other departmental tasks, such as committee work, for regular full-time faculty. Consistent with Pisani and Stott's study, 28 (46.7\%) public department chairs and 8 (37.5\%) private chairs in this research responded strongly against having part-time faculty serve on college and departmental committees. In addition, 29 (48.3\%) public department chairs and 25 $(52.1 \%)$ private chairs responded against having part-time faculty serve on college and 
departmental committees. As Pisani and Stott note, the primary role of part-time faculty is teaching, not advising; consistent with the responses from chairs in this study.

The fifth research question asked: According to department chairs, to what extent are adjunct faculty satisfied with employment conditions in the department and is there a significant difference between public and private institutions in the perceptions of department chairs as to the extent adjunct faculty are satisfied with employment conditions in the department?

This research question was answered by analyzing responses to survey questions 57 through 67 using crosstab analysis, by providing descriptive statistics, frequencies, and percentages.

A moderate but not significant association was found between the type of school (public/private) and survey question 57, about adjunct faculty satisfaction with their part-time status. As to satisfaction of adjunct part-time status, 36.7\% $(n=22)$ of department chairs from public institutions and $47.8 \%(n=22)$ of department chairs from private institutions were not sure if adjunct faculty were satisfied with their part-time status. This finding is consistent with Gappa and Leslie's (1993) study that found that full-time faculty members generally know of the substandard working conditions (i.e., part-time status and low compensation) of adjunct faculty. Public and private school chairs' responses to the question of adjunct salaries satisfaction were similar. For example, $29(48.3 \%)$ chairs from public institutions and $28(60.9 \%)$ chairs from private institutions responded that adjunct faculty members are not satisfied with their salaries. This finding is consistent with Finucane and Algren's (1997) and Gappa and Leslie's (1993) studies. They suggested that because adjuncts are often treated as transient or temporary workers with selection often resulting in last minute, one-semester contracts by the institutions, there is some fear that well qualified faculty cannot be hired due to low compensation. This fear 
is perhaps more evident in the way the public institution department chairs responded, because limited budgets, increased enrollments, and lack of full-time faculty are often more prevalent in public institutions as compared to private institutions.

Rarely are adjunct faculty members eligible for salary increases from one year to the next Fountain, 2005; Fulton, 2000; Gappa, 2000; Gappa \& Leslie, 1993; Kelly, 1991; Lankard, 1993; Pollington, 1991, 1992; Twigg, 1989; Wyles, 1998). This study reveals a similar pattern. For example, $31(52.5 \%)$ chairs from public institutions and $20(44.4 \%)$ chairs from private institutions responded that adjunct faculty members are not eligible for salary increases from one year to the next.

The issue of promotion is also a concern for adjunct faculty (Kelly, 1991; Mize, 1998; Pollington, 1991). There are limited, if any, opportunities for promotion for adjunct faculty members according to the AAUP (1998). Results from this study are consistent with AAUP. For example, $31(51.7 \%)$ chairs from public institutions and $21(45.7 \%)$ chairs from private institutions responded that adjunct faculty members are not provided opportunities for promotion in higher education.

As to secretarial support adjunct faculty members receive, Gappa and Leslie (1993) and Roueche et al. (1995) note it is not provided for an overwhelming number of adjuncts teaching in higher education. In this study, responses were mixed. For example, 29 (48.3\%) chairs from public institutions and $19(41.3 \%)$ chairs from private institutions responded that adjunct faculty members are satisfied with secretarial support they receive. However, 22 (36.7\%) chairs from public institutions and $16(34.8 \%)$ chairs from private institutions responded that they were not sure if adjunct faculty members are satisfied with secretarial support they receive. 
Finally, as Fulton (2000) and Gappa (2000) note, adjunct faculty often seek additional courses to teach at other institutions to compensate for the lack of credit hours currently teaching. Interestingly, the responses in this study again mixed. Department chairs from public institutions $29(48.3 \%)$ and $15(32.6 \%)$ chairs from private institutions responded that they were not sure if adjunct faculty members are satisfied with the number of credit hours they can presently teach. In contrast, chairs from public institutions $23(38.3 \%)$ and $18(39.1 \%)$ chairs from private institutions responded that adjunct faculty members are satisfied with the number of credit hours they can presently teach.

While there were small to moderate associations between the type of school (public/private) and survey items in research question five, none of these associations were significant. Conducting a One-Way ANOVA, there was no significant difference between chairs from public and those from private institutions on their composite scores in the area of the extent adjunct faculty are satisfied with employment conditions in the department.

\section{Recommendations for Practice}

With the number of part-time faculty at colleges and universities in the United States passing the $65 \%$ level, it is imperative for higher education institutions to know who these individuals are, why they teach part-time, what their concerns are, and how their status as "invisible faculty" can be improved. Furthermore, having a better understanding of the demographics, characteristics, and needs of part-time faculty will lead to better systems for administrators and department chairs to identify, hire, and retain the most qualified individuals for part-time positions. This research provides valuable insight into the use of adjunct and parttime faculty as perceived by department chairs. 
Some specific recommendations are additional training for chairs on student centered teaching. For instance, although most chairs agreed with the statement that adjunct faculty members are encouraged to use student-centered effective learning practices, a surprising number of chairs were unsure and some even disagreed with their use.

Institutions should develop policies for formal evaluations of adjuncts that include evaluation in the classroom by peer faculty members and institutional student evaluations at the conclusion of each course. Chairs from both public and private institutions agreed with the statement that adjunct faculty need to participate in the evaluation process, but many were unsure as to how often and by whom.

Department chairs should provide adjunct faculty an understanding of the program's mission and learning outcomes. While the majority of chairs from both public and private institutions agreed with the statement that adjunct faculty members need to have an understanding of the program's mission and learning outcomes, a number of chairs were unsure.

Finally, make clear to adjunct faculty the department's and institution's expectations. The majority of chairs agreed with the statement that adjunct faculty members understand what the department and institution expects of them. Surprisingly, a number of chairs were unsure if adjunct faculty members understand what the department and institution expects of them.

\section{Recommendations for Further Study}

The reader must understand that there are numerous factors that are unknown to or unaccounted for by the researcher such as the actual head count of students in specific departments, as this information was corrupted and therefore excluded from this research. Also, this researcher was unclear as to why some survey questions were not answered. Furthermore, 
the findings and conclusions of this study were based on a relatively small sample size and significantly limit the generalizing the information contained herein.

Some specific recommendations for further study are:

$>$ Increase sample size i.e., several states and greater representation of academic departments other than liberal arts and sciences

$>$ Survey deans in addition to department chairs

$>$ Chairs and part-time faculty take part in a similar survey to measure agreement in how chairs and faculty perceive the status of part-time faculty

It is the hope of the researcher that the information provided by this study will be used as a solid stepping stone for further research. In addition, the researcher hopes the findings, conclusions, and recommendations will provide information for department chairs and administrators to improve the status and use of part-time faculty within all institutions. 


\section{References}

American Association of University Professors (AAUP). (1998). Statement from the conference on the growing use of part-time and adjunct faculty. Academe, 84(1), 54-60.

American Association of University Professors. (2006). Contingent appointments and the academic profession (2003). In Policy documents and reports, (10th ed., pp. 98-114) Washington, DC: Author.

American Association of University Professors. (2007). Trends in faculty status, 1975-2007: All degree-granting institutions; national totals. U.S. Department of Education, IPEDS Fall Staff Survey. Retrieved from http://www.aaup.org/NR/rdonlyres/7D01E0C7-C255-41F19F11-E27D0028CB2A/0/TrendsinFacultyStatus2007.pdf

Anderson, E. L. (2002). The new professoriate: Characteristics, contributions and compensation. Washington, DC: American Council on Education.

Antony, J. S. \& Valadez, J. R. (2002). Exploring the satisfaction of part-time college faculty in the United States. Review of Higher Education, 26(1), 41-56.

Aronowitz, S. (1998). The last good job in America. In R. Martin (Ed.), Chalk lines: The politics of work in the managed university (pp. 202-221). Durham, NC: Duke University Press.

Avakian, N. A. (1995). Conflicting demands for adjunct faculty. Community College Journal, 65 (6), 34-36.

Balch, P. (1999). Part-time faculty are here to stay. Planning for Higher Education, 27(3), 32-41.

Baldwin, R. G. \& Chronister, J. L. (2001). Teaching without tenure: Policies and practices for a new ara. Baltimore: Johns Hopkins Press.

Banachowski, G. (1996a). Perspectives and perceptions: The use of part-time faculty in community colleges. Community College Review, 24(2), 49-62. 
Banachowski, G. (1996b). Perspectives and perceptions: A review of the literature on the use of part-time faculty in community colleges. (ERIC No. ED 398943)

Banachowski, G. (1997). Advantages and disadvantages of employing part-time faculty in community colleges. (ERIC No. ED405037)

Baron-Nixon, L. (2007). Connecting non full-time faculty to institutional mission: A guidebook for college/university administrators \& faculty developers. Sterling, VA: Stylus.

Behrendt, R. L., \& Parsons, M. H. (1983). Evaluation of part-time faculty. In A. Smith (Ed.), Evaluating Faculty and Staff (pp. 33-43). San Francisco: Jossey-Bass.

Beman, R. R. (1980). Observations of an adjunct faculty member. New Directions for Community Colleges, 30, 81-84.

Benjamin, E. (1998). Variations in the characteristics of part-time faculty by general fields of instruction and research. New Directions for Higher Education, 26(4), 45-59.

Benjet, R. G., \& Loweth, M. (1989). A perspective on the academic underclass, the part-timers. Teaching English in the Two-Year College, 16(1), 40-42.

Berger, A., Kirshtein, R. \& Rowe, E. (2001). Institutional policies and practices: Results from the 1999 national study of postsecondary faculty (NSOPF: 99), Institution survey. (ERIC No. ED 457732)

Berger, A., Kirshstein, R., Zhang, Y., \& Carter, K. (2002). A profile of part-time faculty: Fall 1998. (National Center for Education Statistics Work Paper No. 2002-08) Washington, DC: U.S. Department of Education.

Best, J. W., \& Kahn, J. V. (1998). Research in education ( $8^{\text {th }}$ ed.). Boston: Allyn and Bacon.

Biles, G. E., \& Tuckman, H. P. (1986). Part-time faculty personnel management policies. New York: Macmillan. 
Blancard, R. O., \& Christ, W. G. (1993). Media education and the liberal arts: A blueprint for the new professionalism. Hillsdale, NJ: Lawrence Erlbaum.

Bolge, R. D. (1995). Examination of student learning as a function of instructor status (Full-time versus Part-time) at Mercer County Community College. (ERIC No. ED382241)

Bridges, W. (1994). The end of the job. Fortune, 130(6), 61-74.

Burgess, L. A., \& Samuel, C. (1999). Impact of full-time versus part-time instructor status on college student retention and academic performance in sequential courses. Community College Journal of Research and Practice, 23(5), 487-498.

Burke, J. C., Modarresi, S., \& Serban, A. M. (1999, November/December). Performance: Shouldn't it count for something in state budgeting? Change, 31(6), 16-23.

Burns, M. (1992). Women, part-time faculty, and illusion. The NEA Higher Education Journal, $8(1), 13-28$.

Cataldi, F. E., Fahimi, M., \& Bradburn, E. M., (2005). 2004 National Study of Postsecondary Faculty (NSOPF:04) Report on Faculty and Instructional Staff in Fall 2003 (NCES 2005-172). U.S. Department of Education. Washington, DC: National Center for Education Statistics. Retrieved from http://nces.ed.gov/pubsearch

Centra, J. A. (1983). Research productivity and teaching effectiveness. Research in Higher Education, 18(4), 379-389.

Christensen, C. (2008). The employment of part-time faculty at community colleges. New Directions for Higher Education, 143, 29-36.

Clark, B. R. (1997). Small worlds, different worlds: The uniqueness and troubles of American academic professions. Daedulus, 126(4), 21-42.

Clery, S. (1998). Faculty in academe. NEA Higher Education Research Center Update, 4(4), 1-8. 
Cline, L. (1993). Work to school transition: Part-time faculty bring expertise, challenges to colleges. Vocational Education Journal, 68(2), 26-49.

Cohen, A.M. (1992). Benefits on a budget: Addressing adjunct needs. Paper presented at the annual meeting of the speech communication association, Chicago, IL.

Cohen, A. M. \& Brawer, F. B. (1996). The American community college (3rd ed.). San Francisco: Jossey-Bass.

Conley, V. M., Leslie, D. W., \& Zimbler, L. J. (2002). Part-time instructional faculty and staff: Who they are, what they do, and what they think. Washington, DC: U.S. Department of Education. National Center for Education Statistics.

Creswell, J. W. (2003). Research design: Qualitative, quantitative, and mixed methods approaches ( $2^{\text {nd }}$ ed.). Thousand Oaks, CA: Sage

Curtis, J. (2005). Trends in faculty status, 1975-2003. Washington, DC: American Association of University Professors. Retrieved from http://www/aaup.org/research/FacstatTrends.htm

Curtis, J. \& Jacobe, M. F. (2006). Consequences: An increasingly contingent faculty. AAUP Contingent Faculty Index. Retrieved from http://www.aaup.org/NR/rdonlyres/F05FF88EB2A8-4052-8373 $\underline{\text { AF0FDAE060AC/0/ConsequencesAnIncreasinglyContingentFaculty.pdf }}$

Curzon-Brown, D. (1988). The gripes of wrath. Teaching English in the Two-Year College, 15(3), 195-198.

Delaney, B. (2001, January 11). Second-class careerists? The long halls of ivy: Adjunct professors. Retrieved from http://www.cnn.com/2001/CAREER/trends/01/110adjunct/index.html 
Dickinson, R. (1997). The changing role of community college faculty: Implications in the literature. Community College Review, 26(4), 25-31.

Digranes, J. L. A., \& Digranes, S. H. (1995). Current and proposed uses of technology for training part-time faculty. Community College Journal of Research and Practice, 19(2), 161-169.

Ehrenberg, R. G. \& Zhang, L. (2005). The changing nature of faculty. In R. Clark and J. Ma (Eds.), Recruitment, retention and retirement in higher education: Building and managing the faculty of the future (pp. 32-52). Northampton, MA: Edward Elgar.

Ehrenberg, R. G. \& Zhang, L. (2004, summer). Do tenured and tenure-track faculty matter? Journal of Human Resources, 40, 647-659.

Eliason, N. C. (1980). Part-time faculty: A national perspective. New Directions for Community Colleges, 30, 1-12.

Elman, S. E. (2003, fall). A regional accreditation perspective on contingent faculty appointments. New Directions for Higher Education, 123, 71-78.

Erwin, J., \& Andrews, H. A. (1993). State of part-time faculty services at community colleges in a nineteen-state region. Community College Journal of Research and Practice, 17(6), $555-562$.

Evelyn, J. (2002, March 8). Part-time instructors in Washington State win tentative settlement for retirement benefits. The Chronicle of Higher Education. Retrieved from http://www.chronicle.com

Farrell, T. J. (1992). How to kill higher education. Academe, 78(6), 30-33.

Fedler, F., Counts, T., \& Stoner, K. R. (1989). Adjunct profs grade higher than faculty at three schools. Educator, 44(2), 32-37. 
Finucane, M. C., \& Algren, M. E. (1997, November). A pilot study investigation of the socialization of part-time faculty members in academic settings. Paper presented at the Annual Meeting of the National Communication Association, Chicago, IL. (ERIC No. ED 424 596)

Foster, D., \& Foster, E. (1998). It's a buyer's market: Disposable professors, grade inflation, and other problems. Academe, 84(1), 29-35.

Fountain, W. V. (2005). Academic sharecroppers: Exploitation of adjunct faculty and the higher education system. Bloomington, IN: Authorhouse.

Freeland, R. S. (1998). Adjunct faculty in the community college. (ERIC No. ED424899)

Friedlander, J. (1980). Instructional practices of part-time faculty. New Directions for Community Colleges, 30, 27-36.

Frostburg State University Faculty Handbook. (2008). Frostburg State University, Frostburg, MD.

Fulton, R. D. (2000, May/June).The plight of part-timers in higher education. Change, 32(3), 3843.

Gappa, J. M. (1984). Part-time faculty: Higher education at a crossroads. ASHE-ERIC Higher Education Research Report No. 3. Washington, DC: Association for the Study of Higher Education.

Gappa, J. M. (2002, January). Attracting and retraining part-time faculty: Equitable employment policies and practices. Paper presented at Making Part-time Faculty Genuine Partners in the Academic Community/American Association of Higher Education Conference on Faculty Roles and Rewards, Phoenix, AZ. 
Gappa, J. M. (2000). The new faculty majority: Somewhat satisfied but not eligible for tenure. New Directions for institutional research, 105, 77-86.

Gappa, J. M., \& Leslie, D. W. (1993). The invisible faculty: Improving the status of part-timers in higher education. San Francisco: Jossey-Bass.

Gappa, J. M., \& Leslie, D. W. (1997). Two faculties or one? The conundrum of part-timers in a bifurcated work force. Washington, DC: American Association for Higher Education.

Gappa, J. M., Austin, A. E. \& Trice, A. G. (2007). Rethinking faculty work: Higher education's strategic imperative. San Francisco: Jossey-Bass.

German, K. M. (1996, September). Part-time faculty: Identifying the trends and challenges. Journal of the Association for Communication Administration, 3, 231-241.

Green, D. W. (2007). Adjunct faculty and the quest for quality. New Directions for Community Colleges, 140, 29-39.

Greive, D. E., \& Worden, C. A., (Eds.). (2000). Managing adjunct \& part-time faculty for the new millennium. Elyria, $\mathrm{OH}$ : Info-Tec.

Grenzke, J. (1998). Part-time faculty: Quality issues. Washington, DC: (ERIC No. ED417685)

Haeger, J. D. (1998). Part-time faculty, quality programs, and economic realities. New Directions for Higher Education, 104, 81-88.

Heinzelman, K. (1986). The English lecturers at Austin: Our new M.I.A.'s. Academe, 72, 25-31.

Huffman, J. (1997). Adjuncts and their din of inequities: Transforming complaints into action and results. Retrieved from http://www.eric.ed.gov/PDFS/ED417646.pdf 
Iadevaia, D. G. (1991, November). A comparison of full-time to part-time faculty and full-time to part-time science faculty in terms of student success at Pima Community College. (Ed.D. Major Applied Research Project, Nova University). (ERIC No. ED 339403)

Impara, J. C., Hoerner, J. L., Clowes, D. A., \& Alkins, M. T. (1991). Professional development programs: A comparison of full- and part-time occupational-technical faculty. Community College Catalyst, 21(2), 8-12.

Isaac, S. \& Michael, W. B. (1997). Handbook in research and evaluation: A collection of principle, methods and strategies useful in the planning, design, and evaluation of studies in education and the behavioral sciences ( $3^{\text {rd }}$ ed.). San Diego, CA: Educational and Industrial Testing Services.

Jablin, F. M. (1987). Organizational entry, assimilation, and exit. In F. Jablin, L. Putnam, K. Roberts, \& L. Porter (Eds.), Handbook of organizational communication: An interdisciplinary perspective (pp. 679-740). Newbury Park, CA: Sage.

Jacobs, F. (1998). Using part-time faculty more effectively. New Directions for Community Colleges, 104, 9-18.

Jones, G. R. (1986). Socialization tactics, self-efficacy, and newcomers' adjustments to organizations. Academy of Management Journal, 29, 262-279.

Kelly, D. K. (1990). A human resources development approach to part-time faculty in the community college. Unpublished Master thesis, Claremont Graduate School, Redlands, CA. (ERIC No. ED 316379) 
Kelly, D. K. (1991, May). Part-time faculty in the community college: A study of their qualifications, frustrations, and involvements. Paper presented at the Annual Forum of the Association for Institutional Research, San Francisco. (ERIC No. ED336035)

Kerlinger, F. N. (1986). Foundations of behavioral research ( $3^{\text {rd }}$ ed.). Fort Worth, TX: Holt, Rinehart, \& Winston.

Knapp, L. G., Kelly-Reid, J. E, Whitmore, R. W., \& Miller, E., (2007). Employees in postsecondary institutions, fall 2005 salaries of full-time instructional faculty, 2005-06 (NCES 2007-150). Washington, D.C.: U.S. Department of Education, National Center for Education Statistics. Retrieved from http://nces.ed.gov/pubsearch

Kurzet, R. (1997). Quality versus quantity in the delivery of developmental programs for ESL students. New Directions for Community Colleges, 100, 53-62.

Kronberg, J. R. (2004). Teaching practices of adjunct and full-time faculty by inventories of good practice (Doctoral dissertation, West Virginia University, 2004).

Lankard, B. A. (1993). Part-time faculty in adult and vocational education. Columbus, OH: ERIC Clearinghouse on Adult, Career, and Vocational Education. (ERIC No. ED 363797)

Leatherman, C. (1997). Heavy reliance of low-paid lecturers said to produce faceless departments. The Chronicle of Higher Education, 43(27), A12-A13.

Lee, J. (1997). Part-time employment in academe. Washington, DC: National Education Association. (ERIC No. ED 403807)

Leslie, D. W. (1998). Part-time, adjunct, and temporary faculty: The new majority? (Report of the Sloan Conference on Part-Time and Adjunct Faculty). Arlington, VA: Alfred P. Sloan Foundation. (ERIC No. ED 422771) 
Leslie, D. W., \& Gappa, J. M. (2002). Part-time faculty: Competent and committed. New Directions for Community Colleges, 118, 59-67.

Leslie, D. W., Kellams, S. E., \& Gunne, G. M. (1982). Part-time faculty in American higher education. New York, NY: Praeger.

Littrell, J. L. (1990). Occupational training for the real world: Bridging the classroom to corporation gap. Proceedings of the National Conference on Professional Development of Part-time Occupational/Technical Faculty. Washington, DC: Office of Vocational and Adult Education. (ERIC No. ED 326294)

Longmate, J., \& Cosco, F. (2002, May 3). Part-time instructors deserve equal pay for equal work. The Chronicle of Higher Education, The Chronicle Review, B14.

Lords, E. (1999, October 15). Part-time faculty members sue for better pay and benefits. The Chronicle of Higher Education, A16-18.

Lovas, J. C. (2001). How did we get in this fix? A personal account of the shift to a part-time faculty in a leading two-year college district. In E. E. Schell \& P. L. Stock (Eds.), Moving a mountain (pp. 196-217). Urbana, IL: National Council of Teachers of English.

Lundy, K. L. \& Warme, B. D. (1990). Gender and career trajectory: The case of part-time faculty. Studies in Higher Education, 15(2), 207-222.

Lyons, R. E., McIntosh, M., \& Kysilka, M. L. (2003). Teaching college in an age of accountability. Boston: Allyn \& Bacon.

MacFarland, T. W. (1998). A comparison of final grades awarded by full-time faculty and parttime faculty by academic center for Winter term, 1997. Ft. Lauderdale, FL: Nova Southeastern University. (ERIC No. ED 429482) 
Mangan, K. S. (1991, August 7). Many colleges fill vacancies with part-time professors, citing economy and uncertainty about enrollments. The Chronicle of Higher Education, A 9-10.

Marits, E. (1996). Professional development of adjunct faculty. In V. Bianco- Mathis \& N. Chalofsky, (Eds.), The adjunct faculty handbook. Thousand Oaks, CA: Sage.

Mayhew, L. B., Ford, P. J., \& Hubbard, D. L. (1990). The guest for quality. San Francisco: Jossey-Bass.

McArthur, R. C. (1999). A comparison of grading patterns between full- and part-time humanities faculty: A preliminary study. Community College Review, 27(3), 65-76.

McGuire, J. (1993). Part-time faculty: Partners in excellence. Leadership Abstracts, 6(6), 1-3. (ERIC No. ED 367429)

Mellander, G. A. \& Mellander, N. (1999, July 27). Critical issues - - and therefore opportunities for community colleges. (Report to Congressman M. R. Owens, Congresswoman C. P. Meek, \& to the Congressional Progressive Caucus \& the Progressive Challenge). Fairfax, VA: National Center for Community College Education. (ERIC No. ED 432343)

Mize, R. (1998). Full-time part-time faculty: A proposal for perspective. Sacramento: CA, Community College League of California. (ERIC No. ED 427800)

Monroe, C., \& Denman, S. (1991). Assimilating adjunct faculty: Problems and opportunities. Association for Communication Administration Bulletin, 77, 56-62.

Murphy, M. (2002). Adjuncts should not just be visitors in the academic Promised Land. The Chronicle of Higher Education, 48(29), B14-15.

Nance, G., \& Culverhouse, R. (1991-1992). The hidden costs of part-time faculty. Planning for Higher Education, 20(2), 30-38. National Study of Postsecondary Faculty (NSOPF) (1993). Methodology report. (ERIC No.ED 412292) 
National Center for Education Statistics (1990). Faculty in higher education institutions, 1988. (NCES No. 90-365). Washington, DC: Department of Education.

National Center for Education Statistics (1997a). Instructional faculty and staff in higher education institutions: Fall 1987 and Fall 1992. Washington, DC: Department of Education.

National Center for Education Statistics (1997b). National study of postsecondary faculty NSOPF: 88/92. Washington, DC: Department of Education.

National Education Association Standing Committee on Higher Education. (1987). Part-time, temporary and non-tenure track faculty appointments. Washington, DC: NEA Office of Higher Education.

Osborn, R. (1990). Part-time faculty development. What do we know and what can we use? Community Services Catalyst, 20(2), 17-21.

Parsons, M. H. (1998, April). How the other 2/3 live: Institutional initiatives for part-time faculty assimilation in America's 2-year colleges. Paper presented at the Annual Convention of the AACC, Miami, FL. (ERIC No. ED 417793)

Phelan, A. (1986, June). Boundary-spanning professionals: Value-adding roles for part-time faculty. Pratt Institute's strategy to enhance its curriculum. Paper presented at a conference sponsored by Empire State College on Value-Added Learning: New Strategies for Excellence in Education and Training, Saratoga Springs, NY. (ERIC No. ED 279233)

Phillippe, K. (Ed.). (2000). National profile of community colleges: Trends and statistics $\left(3^{\text {rd }}\right.$ ed.). Washington, DC: Community College Press. 
Pisani, A. M. \& Stott, N. (1998) An investigation of part-time faculty commitment to developmental advising. Research in Higher Education, 39(2), 121-142.

Pollington, M. (1992, March). A tale of two campuses: The part-time English teacher at Brigham Young University and Utah Valley Community College. Paper presented at the Annual Meeting of the Conference on College Composition and Communication, Cincinnati, OH. (ERIC No. ED 345255)

Pollington, M. (1991, March). Part-time teachers—or teachers who work part-time? Paper presented at the Annual Meeting of the Conference on College Composition and Communication, Boston, MA. (ERIC No. ED 331083)

Rhoades, G. (1996). Reorganizing the faculty workforce for flexibility: Part-time professional labor. Journal of Higher Education 67(6), 626-659.

Rhoades, G. (1998). Managed professionals: Unionized faculty and restructuring academic labor. Albany, NY: State University of New York Press.

Rifkin, T. (2000). Public community college faculty. New Expeditions Issues Paper No. 4. Washington, DC: Community College Press.

Rifkin, T. (1998). Differences between the professional attitudes of full-and part-time faculty. Los Angeles, CA: ERIC Clearinghouse for Community Colleges. (ERIC No. ED 417783)

Roderer, L., \& Weissbecker, B. (1990). Perspectives on part-time teaching in community colleges: Pressures, politics, and prospects. Journal of the Virginia Community College Association, 5(1), 28-32.

Roueche, J. E., Roueche, S. D., \& Milliron, M. D. (1995). Strangers in their own land: Part-time faculty in American community colleges. Washington, DC: Community College Press. 
Roueche, J. E., Roueche, S. D., \& Milliron, M. D. (1996a). Identifying the strangers: exploring part-time faculty integration in American community colleges. Community College Review, 23(4), 33-48.

Roueche, J. E., Roueche, S. D., \& Milliron, M. D. (1996b). In the company of strangers: Addressing the utilization and integration of part-time faculty in American community colleges. Community College Journal of Research and Practice, 20(2), 105-117.

Samuel, F. M. (1989). A strategy to eliminate inequality of higher education opportunities by improving adjunct faculty performance. Community College Review, 17(2), 41-47.

Sayer, J. E. (1999). Lecturers, instructors, and part-timers: The person v. the position. Journal of the Association for Communication Administration, 28, 100-103.

Schuetz, P. (2002). Instructional practices of part-time and full-time faculty. New Directions for Community Colleges, 118, 39-46.

Schuster, J. H. \& Finkelstein, M. J. (2006). The American faculty: The restructuring of academic work and careers. Baltimore: The Johns Hopkins University Press.

Selvadurai, R. H. (1990). Advantages and disadvantages of hiring part-time faculty in higher education. Community College Review, 10(1-2), 198.

Sheeks, G. L. (1998). Engaging part-time faculty: Institutional and departmental issues. Paper presented at AAHE Conference on Faculty Roles and Rewards, San Diego, CA.

Silvers, P. J. (1990). Utilization of associate faculty at Pima Community College: A report on surveys of college associate faculty and department heads. Tucson, AZ: Pima Community College, Office of Research and Planning. (ERIC No. ED329320) 
Smallwood, S. (2002, July 22). American federation of teachers' approves standards for treatment of adjuncts. The Chronicle of Higher Education. Retrieved December 1, 2006, from http://www.chronicle.com

Smallwood, S. (2003, February 21). United we stand? The Chronicle of Higher Education, pp. A10-11.

Smith, R. R. (1980). Can participatory programs realize part-time faculty potential? New Directions for Community Colleges, 30, 17-25.

Spangler, M. S. (1990). Part-time faculty: Recognizing an unprotected minority. (Position Paper 120). Los Angeles, CA. (ERIC No. ED 321793)

Spinetta, K. I. (1990). Part-time instructors in the California community colleges: A need to revise current policies. Community College Review, 18(1), 43-49.

Straw, D. (2002, April 15). I'm an adjunct. Community College Week, p. 4.

Styne, M. M. (1997). Those unfamiliar names and faces: The hiring, management, and evaluation of part-time faculty. Teaching English in the Two-Year College, 24 (1), 50-55.

Sworder, S. (1987). Determination of the effect of an instructor's employment status (full-time or part-time) on the decision of students to enroll. (Ed.D. Practicum, Nova University). (ERIC No. ED 277408)

Thompson, D. M. (1995). Alternative approaches to adjunct faculty development. Princeton, NJ: Mid-Career Fellowship Program. Retrieved from ERIC database. (ED384392)

Thompson, K. (1992a). Piecework to parity: Part-timers in action. The NEA Higher Education Journal, 8(1), 29-37.

Thompson, K. (1992b). Recognizing mutual interests: Use of part-time faculty reflects a broader business strategy to minimize pay and maximize control. Academe, 78(6), 22-26. 
Thompson, W. E. \& Hickey, J. V. (2005). Society in focus: An introduction to sociology (5 ${ }^{\text {th }}$ ed). Boston: Allyn \& Bacon.

Townsend, R. B. (2000). Part-time faculty surveys highlight disturbing trends. Perspectives, $38(7)$.

Tucker, A. (1984). Chairing the academic department: Leadership among peers (2 ${ }^{\text {nd }}$ ed.). New York: American Council on Education, MacMillian.

Tucker, A. (1993). Chairing the academic department: Leadership among peers $\left(3^{\mathrm{rd}} \mathrm{ed}.\right)$. Phoenix, AZ: The Onyx Press.

Tuckerman, H. P. \& Pickerill, K. L. (1988). Part-time faculty and part-time academic careers. In W. Breneman \& T.I.K. Youn (Eds.), Academic labour markets and careers. London: Falmer Press.

Tuckman, H.P. (1978). Who is part-time in academe? AAUP Bulletin, p.64.

Tuckman, H. P., \& Tuckman, B. H. (1981). Who are the part-timers and what are colleges doing for them? Current Issues in Higher Education, 4, 4-7.

Twigg, H. P. (1989, November). Uses and abuses of adjunct faculty in higher education. Paper presented at a National Conference of the Community College Humanities Association, Washington, DC. (ERIC No. ED 311984)

Van Maanen, J. (1976). Breaking in: Socialization to work. In R. Dubin (Ed.), Handbook of work, organization, and society (pp. 67-130). Chicago: Rand McNally.

Van Maanen, J., \& Schein, E. H. (1979). Toward a theory of organizational socialization. In B. M. Shaw (Ed.), Research organizational behavior (pp. 209-264). Greenwich, CN: JAI Press. 
U.S. Department of Education, National Center for Education Statistics. (2001, September). Institutional Policies and Practices: Results from the 1999 National Study of Postsecondary Faculty, Institution Survey. Washington, DC: U.S. Government Printing Office.

Wallace, M. E. (1984). The richness of language and the poverty of part-timers: Impact and invisibility. College English, 46, 580-586.

Wallin, D. L. (2007). Part-time faculty and professional development: Notes from the field. New Directions for Community Colleges, 140, 67-73.

Wallin, D. L. (2004). Valuing professional colleagues: Adjunct faculty in community and technical colleges. Community College Journal of Research and Practice, 28, 373-391.

Wallin, D. L., \& Sweet, P. A. (2003). Professional development needs of adjunct faculty in Georgia technical colleges. Report prepared for the Georgia Department of Technical and Adult Education.

Walsh, S. (2002, October 29). Study finds significant increase in number of part-time and nontenure-track professors. The Chronicle of Higher Education. Retrieved from http://www.chronicle.com

Warme, B., \& Lundy, K. (1988). Erosion of an ideal: The presence of part-time faculty. Studies in Higher Education, 13(2), 201-213.

Weisman, I. M., \& Marr, J. W., Jr. (2002). Building community: The second century, same challenge. New Directions for Community Colleges, 118, 99-107.

Weglarz, S. (1998). Johnson County Community College (JCCC) survey of adjunct faculty, 1997. (ERIC No. ED 430652) 
Williams, J. P. (1994). Part-time evaluation: A campus case study. Proceedings of the National Conference on Successful College Teaching. Gainesville, FL: Institute of Higher Education. Retrieved from ERIC database. (ED390454)

Wilson, R. (1996, June 7). Scholars off the tenure track wonder if they'll ever get on. The Chronicle of Higher Education, p. A13. Retrieved from http://www.chronicle.com

Witt, A., Wattenbarger, J., Gollattscheck, J., \& Suppiger, J. (1994). America's community colleges. Washington, DC: Community College Press.

Wyles, B. A. (1998). Adjunct faculty in the community college: Realities and challenges. New Directions for Higher Education, 26(104), 89-93.

Zimbler, L. J. (2001). Background characteristics, work activities, and compensation of faculty and instructional staff in postsecondary institutions (NCES 2001-152). Washington, DC: National Center for Education Statistics. 
Appendix A

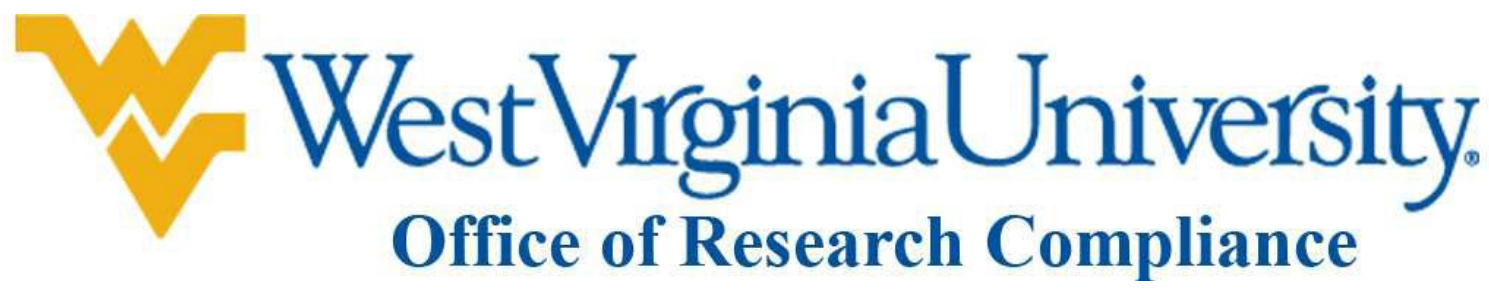

Expedited-IRB Protocol-Exemption

To: Goeres, Ernest

From: WVU Office of Research Compliance

Date: Wednesday, June 09, 2010

Subject: Exemption Acknowledgement

Tracking \#: H-22458

Title: DEPARTMENT CHAIRS' PERCEPTIONS OF PART-TIME FACULTY STATUS IN MARYLAND PRIVATE AND PUBLIC HIGHER EDUCATION INSTITUTIONS

The above-referenced study was reviewed by the West Virginia University Institutional Review Board (IRB) and was granted exemption in accordance with 45 CFR 46.101(2). This protocol was reviewed using the following:

Exemption Checklist (210r)

This research study was granted an exemption because the Research involves educational tests, survey procedures, interview procedures or observation of public behavior and (i) information obtained is recorded in such a manner that human subjects cannot be identified, directly or through identifiers linked to the subjects; and (ii) any disclosure of the human subjects' responses outside the research could not reasonably place the subjects at risk of criminal or civil liability or be damaging to the subjects' financial standing, employability, or reputation [45 CFR 46.101(2)].

The following documents have been acknowledged for use in this study and are available in the BRAAN system:

Surveys, Questionnaires, Interviews

Attachments

Department chairs survey.doc 


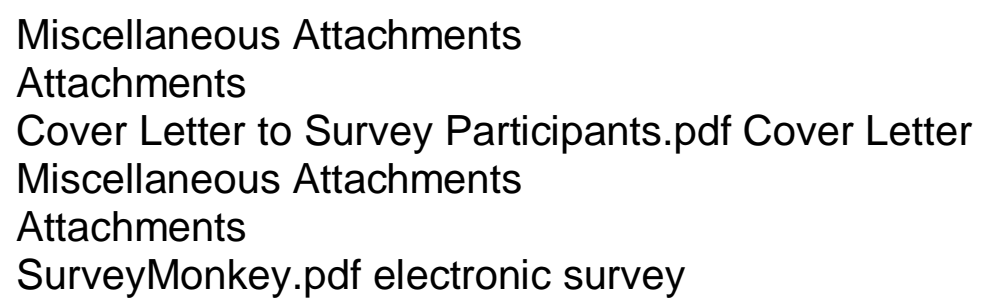

Thank you.

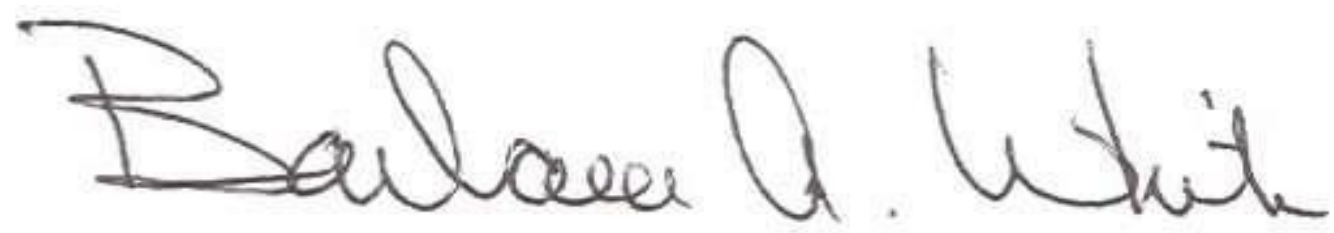

Board Designee: White, Barbara

Letter Sent By: White, Barbara, 6/9/2010 2:49 PM

Once you begin your human subject research, the following regulations apply:

1. Any modifications to the study protocol must be reviewed and acknowledged by the IRB prior to implementation.

2. You may not use a modified form until it has been acknowledged by the IRB. 
Appendix B

\section{WestVirginiaUniversity。}

College of Human

Resources \& Education

\section{Cover Letter to Survey Participants}

Dear Faculty Department Chairs:

I am requesting your participation in a study I am conducting for my doctoral dissertation in Educational Leadership Studies at West Virginia University (WVU). The purpose of the study is to describe the status of adjunct faculty in Maryland private and public four year colleges and universities as perceived by department chairs and to determine if there are (a) significant differences in department chairs perceptions according to (adjunct faculty professional commitments), (adjunct faculty evaluations), (adjunct faculty integration into the department), (performance expectations of adjunct faculty), and (adjunct faculty employment satisfaction), and (b) determine whether there are significant demographical differences between them, such as private versus public, size, number of adjuncts employed, and the like.

As you know, the increasing use of adjunct/part-time faculty appears to be a national trend but Maryland institutions have varying policies and rates of utilization. By studying the status of adjunct/part-time faculty in Maryland, department chairs and administrators can determine how best to serve their perspective faculty and students.

Your responses to the electronic survey http://www.surveymonkey.com/s/NCXZKSP will be confidential since no individual answers will be shared at any time and your participation in this study is completely voluntary and you do not have to respond to every item. This survey should take approximately 10-15 minutes to complete.

WVU's Institutional Review Board for the Protection of Human Subjects has approved this study.

Thank you in advance for taking your valuable time to participate in the study. If you have any questions, please contact Daniel Moorehead at 301-687-7965 or dlmoorehead @ frostburg.edu. Sincerely,

Ernest Goeres, Ph.D.

Professor

West Virginia University

Principal Investigator

304-293-2088

Ernest.Goeres@mail.wvu.ed
Daniel Moorehead

Doctoral Candidate

West Virginia University

Co-Investigator

301-687-7965

dlmoorehead@frostburg.edu
Phone: 304-293-3707

Fax: 304-293-2279

\author{
Educational Leadership Studies \\ 608 Allen Hall \\ Morgantown, WV 26506
}




\section{Appendix C}

Part-time Faculty Survey (Department Chairs)

1. What is the name of your institution?

2. What is your department name?

3. What is your Gender? - Male Female

4. How many years have you served as the department chair? (1-5) (6-10) (11-15) (16-20) (21-25) (more than 25)

5. How many years have you taught in a college or university? (1-5) (6-10) (11-15) (16-20) (21-25) (more than 25)

6. What type of institution are you currently employed by? Public___ Private

7. What is the highest degree you earned? Doctorate Masters Other

8. What is the type of school where you received your degree?

Public Private

9. How many Adjuncts were hired last year? Male Female

10. Please indicate how many adjuncts you employed by their ethnicity during the past academic year (White ) (Black ) (Hispanic ) (Asian ) (Other )

11. How many headcount students are currently enrolled in your program ?

12. Who makes the decision about hiring adjunct faculty in your department?

13. What is/are the main reason(s) for hiring adjunct faculty in your department?

14. What is the maximum number of credit hours that your adjuncts are allowed to teach a semester? (1-3)

(more than 9)

15. How difficult do you find it to identify and employee qualified adjunct faculty to meet your programs needs?

(Extremely Difficult) (Very Difficult) (Difficult) (Somewhat Difficult) (Not Difficult at All) 
16. Additional comments about hiring adjunct faculty?

\section{According to department chairs, to what extent is information collected on the professional commitments of their adjunct faculty?}

Please complete the following items by circling the number that best reflects your perception of part-time faculty's status using a Likert scale. The scale would range from 5 to 1 as follows: 5 - Strongly Agree, 4 - Agree, 3 - Not Sure, 2 - Disagree, 1 - Strongly Disagree

17. Adjunct faculty commitments at other institutions is a concern for me 5- Strongly Agree, 4 - Agree, 3 - Not Sure, 2 - Disagree, 1 - Strongly Disagree

18. Adjunct faculty teaching at other colleges and universities should not exceed four courses 5- Strongly Agree, 4 - Agree, 3 - Not Sure, 2 - Disagree, 1 - Strongly Disagree

19. Adjunct faculty are required to share information with department chairs regarding other professional commitments

5- Strongly Agree, 4 - Agree, 3 - Not Sure, 2 - Disagree, 1 - Strongly Disagree

20. There is a limit on the number of courses adjunct teach elsewhere

5- Strongly Agree, 4 - Agree, 3 - Not Sure, 2 - Disagree, 1 - Strongly Disagree

21. Adjunct faculty are required to inform department chairs of other professional workload obligations

5- Strongly Agree, 4 - Agree, 3 - Not Sure, 2 - Disagree, 1 - Strongly Disagree

22. Having several outside professional commitments raises concern in their employability

5- Strongly Agree, 4 - Agree, 3 - Not Sure, 2 - Disagree, 1 - Strongly Disagree

23. There should be limitations on outside professional commitments for adjunct faculty

5- Strongly Agree, 4 - Agree, 3 - Not Sure, 2 - Disagree, 1 - Strongly Disagree

24. My institution has a set hiring policy or contract for adjunct faculty

5- Strongly Agree, 4 - Agree, 3 - Not Sure, 2 - Disagree, 1 - Strongly Disagree 
25. Locally recruited adjunct faculty are less competent than those hired through national searches

5- Strongly Agree, 4 - Agree, 3 - Not Sure, 2 - Disagree, 1 - Strongly Disagree

26. Due to their lack of full-time commitment, adjunct faculty devote insufficient time and attention to their students

5- Strongly Agree, 4 - Agree, 3 - Not Sure, 2 - Disagree, 1 - Strongly Disagree

27. Not every adjunct is hired for reasons of cost; many are hired to meet special teaching needs

5- Strongly Agree, 4 - Agree, 3 - Not Sure, 2 - Disagree, 1 - Strongly Disagree

28. Adjunct faculty are often retained and reappointed over extended periods of time despite non-tenure-track instructional titles

5- Strongly Agree, 4 - Agree, 3 - Not Sure, 2 - Disagree, 1 - Strongly Disagree

2. According to department chairs, to what extent are adjunct faculty evaluated and what evidence is required?

29. Adjunct faculty should be evaluated the same as full time faculty

5- Strongly Agree, 4 - Agree, 3 - Not Sure, 2 - Disagree, 1 - Strongly Disagree

30. Adjunct faculty should be evaluated in the classroom by peer faculty members

5- Strongly Agree, 4 - Agree, 3 - Not Sure, 2 - Disagree, 1 - Strongly Disagree

31. Adjunct faculty should be evaluated by Institutional student evaluations at the end of the class

5- Strongly Agree, 4 - Agree, 3 - Not Sure, 2 - Disagree, 1 - Strongly Disagree

32. Adjunct faculty should be evaluated by department chairs only

5- Strongly Agree, 4 - Agree, 3 - Not Sure, 2 - Disagree, 1 - Strongly Disagree

33. Evaluation of teaching effectiveness is mandatory

5- Strongly Agree, 4 - Agree, 3 - Not Sure, 2 - Disagree, 1 - Strongly Disagree 
34. Our institution has policies for formal evaluation of adjuncts

5- Strongly Agree, 4 - Agree, 3 - Not Sure, 2 - Disagree, 1 - Strongly Disagree

35. Adjunct faculty do evaluate themselves through informal methods

5-Strongly Agree, 4 - Agree, 3 - Not Sure, 2 - Disagree, 1 - Strongly Disagree

36. Part-time, adjunct faculty are very effective teachers

5- Strongly Agree, 4 - Agree, 3 - Not Sure, 2 - Disagree, 1 - Strongly Disagree

37. Evaluations for adjunct faculty are consistently higher than for tenure-track faculty members

5- Strongly Agree, 4 - Agree, 3 - Not Sure, 2 - Disagree, 1 - Strongly Disagree

38. The use of adjunct faculty will continue to grow in the future

5- Strongly Agree, 4 - Agree, 3 - Not Sure, 2 - Disagree, 1 - Strongly Disagree

\section{According to department chairs, to what extent do adjunct faculty become integrated into the department?}

39. Adjunct faculty understand the program's mission

5- Strongly Agree, 4 - Agree, 3 - Not Sure, 2 - Disagree, 1 - Strongly Disagree

40. Adjunct faculty understand the program's learning outcomes

5- Strongly Agree, 4 - Agree, 3 - Not Sure, 2 - Disagree, 1 - Strongly Disagree

41. Adjunct faculty understand how courses they teach fit into the appropriate academic programs

5- Strongly Agree, 4 - Agree, 3 - Not Sure, 2 - Disagree, 1 - Strongly Disagree

42. Students report that adjunct faculty are rarely available for advising

5- Strongly Agree, 4 - Agree, 3 - Not Sure, 2 - Disagree, 1 - Strongly Disagree

43. Adjunct faculty are included in planning discussions about current and projected course offerings

5-Strongly Agree, 4 - Agree, 3 - Not Sure, 2 - Disagree, 1 - Strongly Disagree 
44. Adjunct faculty are included in planning discussions about current and projected use of resource allocations, budget projections, and actual and anticipated sources of revenue

5- Strongly Agree, 4 - Agree, 3 - Not Sure, 2 - Disagree, 1 - Strongly Disagree

45. Adjunct faculty are included in the formulation of strategies and plans that reflect the mission and educational objectives of the department and institution

5- Strongly Agree, 4 - Agree, 3 - Not Sure, 2 - Disagree, 1 - Strongly Disagree

\section{According to department chairs, to what extent are performance expectations explained to adjunct faculty?}

46. Adjunct faculty are expected to maintain regular office hours

5- Strongly Agree, 4 - Agree, 3 - Not Sure, 2 - Disagree, 1 - Strongly Disagree

47. Adjunct faculty are expected to serve as an advisor to students

5- Strongly Agree, 4 - Agree, 3 - Not Sure, 2 - Disagree, 1 - Strongly Disagree

48. Adjunct faculty are expected to develop their course syllabi

5- Strongly Agree, 4 - Agree, 3 - Not Sure, 2 - Disagree, 1 - Strongly Disagree

49. Adjunct faculty are expected to conduct assessments of student learning

5- Strongly Agree, 4 - Agree, 3 - Not Sure, 2 - Disagree, 1 - Strongly Disagree

50. Adjunct faculty are expected to use student-centered effective teaching techniques

5- Strongly Agree, 4 - Agree, 3 - Not Sure, 2 - Disagree, 1 - Strongly Disagree

51. Adjunct faculty are expected to engage in and publish research

5- Strongly Agree, 4 - Agree, 3 - Not Sure, 2 - Disagree, 1 - Strongly Disagree

52. Adjunct faculty are expected to be involved in governance issues

5- Strongly Agree, 4 - Agree, 3 - Not Sure, 2 - Disagree, 1 - Strongly Disagree

53. Adjunct faculty are expected to serve on college and departmental committees

5- Strongly Agree, 4 - Agree, 3 - Not Sure, 2 - Disagree, 1 - Strongly Disagree 
54. Adjunct faculty are expected to serve on student committees

5- Strongly Agree, 4 - Agree, 3 - Not Sure, 2 - Disagree, 1 - Strongly Disagree

55. Adjunct faculty members fully understand the expectations of satisfactory performance 5- Strongly Agree, 4 - Agree, 3 - Not Sure, 2 - Disagree, 1 - Strongly Disagree

56. Adjunct faculty members understand their role in contributing to the overall curriculum 5- Strongly Agree, 4 - Agree, 3 - Not Sure, 2 - Disagree, 1 - Strongly Disagree

\section{According to department chairs, to what extent are adjunct faculty satisfied with employment conditions in the department?}

57. Adjunct faculty are satisfied with their part-time status

5- Strongly Agree, 4 - Agree, 3 - Not Sure, 2 - Disagree, 1 - Strongly Disagree

58. Adjunct faculty are more satisfied as a contractual employee rather than part-time employee status

5- Strongly Agree, 4 - Agree, 3 - Not Sure, 2 - Disagree, 1 - Strongly Disagree

59. Adjunct faculty are satisfied with their salaries

5- Strongly Agree, 4 - Agree, 3 - Not Sure, 2 - Disagree, 1 - Strongly Disagree

60. Adjunct faculty are eligible for salary increases from one year to the next

5- Strongly Agree, 4 - Agree, 3 - Not Sure, 2 - Disagree, 1 - Strongly Disagree

61. Adjunct faculty are satisfied with the conditions for reappointment

5- Strongly Agree, 4 - Agree, 3 - Not Sure, 2 - Disagree, 1 - Strongly Disagree

62. Adjunct faculty have opportunities for promotion

5- Strongly Agree, 4 - Agree, 3 - Not Sure, 2 - Disagree, 1 - Strongly Disagree

63. Adjunct faculty are satisfied with secretarial support they receive

5- Strongly Agree, 4 - Agree, 3 - Not Sure, 2 - Disagree, 1 - Strongly Disagree 
64. Adjunct faculty are satisfied with office space and equipment made available to them 5- Strongly Agree, 4 - Agree, 3 - Not Sure, 2 - Disagree, 1 - Strongly Disagree 65. Adjunct faculty are included in departmental social events

5- Strongly Agree, 4 - Agree, 3 - Not Sure, 2 - Disagree, 1 - Strongly Disagree 66. Adjunct faculty are satisfied with the number of credit hours they can teach at our college 5- Strongly Agree, 4 - Agree, 3 - Not Sure, 2 - Disagree, 1 - Strongly Disagree 67. Our adjunct faculty are hired as part-time employees rather than contractees 5- Strongly Agree, 4 - Agree, 3 - Not Sure, 2 - Disagree, 1 - Strongly Disagree 6. Would you like a summary of the results? Yes No

Name \& address:

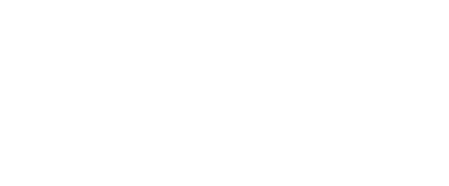

